\section{Pacific Northwest}

National Laboratory

Operated by Battelle for the

U.S. Department of Energy

\title{
Reactive Behavior of K-Basin Spent Nuclear Fuel
}

J. Abrefah
E.R. Siciliano

D.W. Damschen

S.N. Schlahta

September 2002

Prepared for the U.S. Department of Energy under Contract DE-AC06-76RL01830 


\title{
Reactive Behavior of K-Basin Spent Nuclear Fuel
}

\author{
J. Abrefah \\ E. R. Siciliano \\ D. W. Damschen \\ S. N. Schlahta
}

September 2002

Work Supported by

The U.S. Department of Energy

Under Contract DE-AC06-76RL01830

Pacific Northwest National Laboratory

Richland, Washington 99352 


\section{Summary}

The Hanford Spent Nuclear Fuel Project focuses its efforts on determining how to safely move the degraded N-Reactor spent fuel from water-stored basins to a dry storage facility. As part of this effort, the project initiated experimental studies to address issues relating to the chemical reactivity of the degraded/corroded metallic uranium material. The studies generated a limited set of data on chemical reaction rates of the N-Reactor spent fuel in dry-air, moist-air, and moist-inert atmospheres for comparison with published data on unirradiated/irradiated metallic uranium. Based on the laboratory data, the project chose to use a conservative enhancement factor in analyzing the oxidation behavior of the spent metallic fuel. However, there is a need for the project to increase the fuel throughput for the drying-treatment process by implementing certain design optimization steps. The study discussed in this paper re-evaluated the previous laboratory data in conjunction with the cold vacuum drying (CVD) process experience and determined whether the built-in level of conservatism could accommodate the potential changes in the process without compromising public and worker safety.

Evaluations based on laboratory data on samples taken from the corroded N-Reactor spent fuel showed no reactivity enhancement for the degraded metallic uranium in moist atmospheres. The established oxidation reaction-rate constant was used to accurately determine the reactive surface areas of corroded N-Reactor fuel elements. The surface areas calculated for six different N-Reactor elements that were stored in the K-West Basin and shipped to Pacific Northwest National Laboratory for drying studies ranges from as low as $0.0018 \mathrm{~m}^{2}$ for a broken element to $8.1 \mathrm{~m}^{2}$ for a highly corroded spent nuclear fuel (SNF) element $5744 \mathrm{U}$ based on the measured reaction-rate constant for the K-Basin SNF $\left(\mathrm{k}_{\mathrm{SNF}}\right)$. On the other hand, if the literature-averaged rate constant $\left(\mathrm{k}_{\mathrm{Lit}}\right)$ is used, the calculated areas are between 0.0002 and $1.1 \mathrm{~m}^{2}$.

The SNF element 0309M, which was a clean broken piece, was used to calibrate the calculation method. The result using the SNF reaction rate constant, i.e., $\mathrm{k}_{\mathrm{SNF}}$, gave a very good, i.e., $0.0018 \mathrm{~m}^{2}$, agreement with the geometrical value of $0.0015 \mathrm{~m}^{2}$. The other corroded SNF elements showed high reactive surface areas due to the corroded particulates that were purposefully tested together with these SNF elements.

Having established that the hydrogen generation can be used to determine the exposed surface area of these irregular corroded SNF elements, the established method was then used to provide a good estimate of the exposed uranium surface area of SNF elements loaded into the multi-canister overpacks (MCOs). During the CVD process of drying the SNF in MCOs for the interim dry-storage facility, the gas species downstream from the MCOs are monitored by a residual gas analyzer (RGA). The RGA data were analyzed to estimate the exposed surface areas of the SNF elements in the first batch of MCOs.

The first MCO, i.e., MCO-36, was loaded with SNF elements that had no visible cladding damage. Therefore, the expected outcome from analyzing the data is a low exposed surface area compared to the rest of the MCOs that were loaded with SNF elements with different types of corrosion damage. This hypothesis was conclusively supported by the reactive areas obtained for the eight MCOs analyzed because the area for MCO-36 was about an order of magnitude lower than that of the remaining MCOs. Thus, a very good method for measuring the exposed surface areas of these degraded SNF elements after they were loaded into a sealed container was established. The analysis also provides the avenue to determine the near-term gas evolution rate for these sealed containers. 


\section{Acronyms}

$\begin{array}{ll}\text { CVD } & \text { cold vacuum drying } \\ \text { GC } & \text { gas chromatography } \\ \text { HVD } & \text { hot-vacuum drying } \\ \text { IRT } & \text { Initial Rebound Testing } \\ \text { MCO } & \text { Multi-Canister Overpack } \\ \text { NMFA } & \text { Nuclear Materials Focus Area } \\ \text { PCM } & \text { primary cleaning machine } \\ \text { PNNL } & \text { Pacific Northwest National Laboratory } \\ \text { QA } & \text { Quality Assurance } \\ \text { QARD } & \text { Quality Assurance Requirement Description } \\ \text { RGA } & \text { residual gas analyzer } \\ \text { SNF } & \text { spent nuclear fuel } \\ \text { TGA } & \text { thermo-gravimetric }\end{array}$




\section{Acknowledgements}

The authors are grateful to the Nuclear Materials Focus Area (NMFA) of the U.S. Department of Energy, which provided the funding that made the activities described in this report possible. The authors also would like to express their appreciation to Terry Walton and Bill Bonner of Pacific Northwest National Laboratory, and Raymond Crawford, Joseph Swenson, and Frank Moore of the Hanford Spent Nuclear Fuel. 


\section{Quality Assurance}

This work was conducted under the Quality Assurance Program, Pacific Northwest National Laboratory (PNNL) SNF-70-001, SNF Quality Assurance Program, as implemented by the PNNL SNF Characterization Project Operation Manual. This quality assurance (QA) program has been evaluated and determined to effectively implement the requirements of DOE/RW-0333P, Office of Civilian Radioactive Waste Management Quality Assurance Requirements and Description (QARD). Compliance with the QARD requirements is mandatory for projects, which generate data used to support the development of a permanent High-Level Nuclear Waste repository. Further, the U.S. Department of Energy has determined that the testing activities, which generated the results documented in this report, shall comply with the QARD. 


\section{Contents}

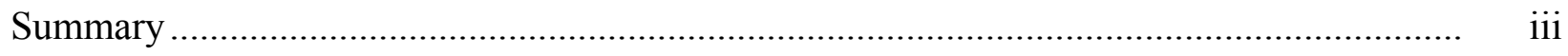

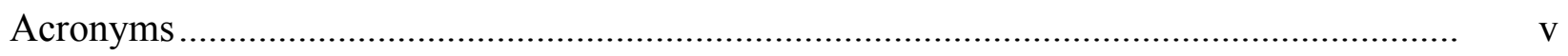

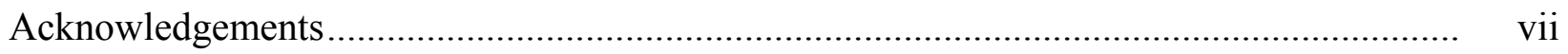

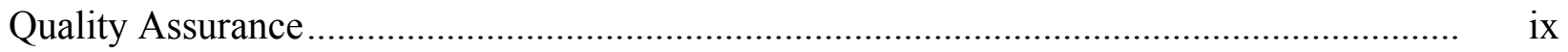

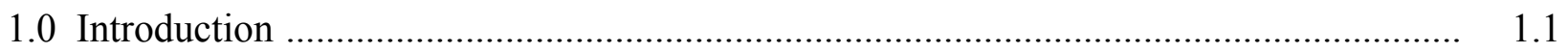

2.0 SNF Oxidation In Moist Atmosphere .......................................................... 2.1

2.1 Moist-Air Oxidation .............................................................................. 2.1

2.2 Moist-Inert Oxidation .............................................................................. 2.2

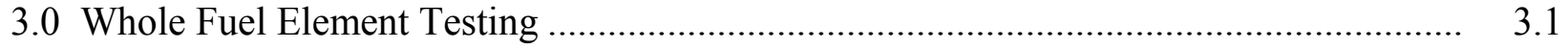

3.1 Fuel Element Surface Area Estimate ................................................................ 3.1

4.0 Surface Area of SNF Elements in MCO .............................................................

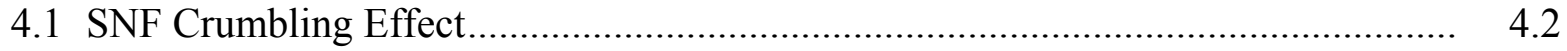

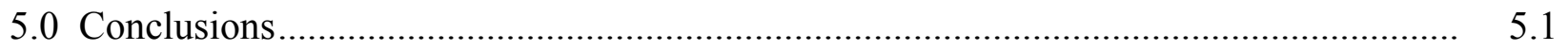

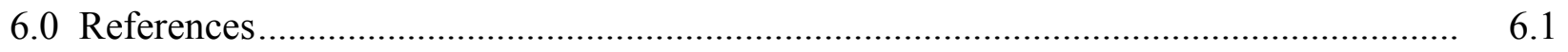

Appendix A: Whole-Element Testing Results.......................................................... A.1

Appendix B: SNF Surface Area in MCOs ........................................................... B.1 


\section{Figures}

1.1. Hanford K-Basin SNF Project Process Flow Diagram

2.1. Comparison of the Oxidation Rate for N-Reactor Fuel in Moist Air with the Calculated Rates

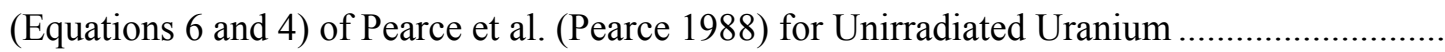

2.2. Comparison of N-Reactor Fuel Material Oxidation Rate with the Published Data for Uranium in Oxygen-Free Water Vapor.

3.1. Drying Results for a Corroded SNF Element-5744U at Different Temperatures.

3.2. Corroded/Damaged SNF Element 5744U

4.1. SNF Particulates and Scrap Generated by Washing Corroded Elements in the PCM

\section{Tables}

3.1. Surface Areas of Damaged K-Basin Spent Fuel Elements

4.1. Total Exposed Uranium Surface Reactive Area of MCO Elements 


\subsection{Introduction}

Spent nuclear fuel from the N-Reactor ${ }^{\mathrm{a}}$ at the Department of Energy's Hanford Site in southeastern Washington State has been stored under water in the 100-Area K-Basins for approximately 30 years. Approximately 2100 metric tons of spent fuel are stored in the two basins: K-West Basin and K-East Basin. The basins are aging, and a portion of the fuel inventory is degraded. A strategy for decommissioning the basins was developed, as was a disposition plan for the 2100 metric tons of spent fuel. The plan for the spent fuel includes recovering the fuel from the basins, repackaging it in large "multi-canister overpacks" (MCOs), subjecting the contents of those canisters to a cold (low-temperature) vacuum drying (CVD) process, sealing the canisters, and moving them to an interim dry storage facility (Canister Storage Building) away from the Columbia River (Figure 1.1).

An aggressive schedule for the Hanford Spent Nuclear Fuel (SNF) Project has precluded research needed to fully understand the chemical behavior of the corroded metallic uranium. Consequently, to assure public and worker safety, a certain measure of conservatism regarding the oxidation rate was built into the SNF treatment strategy. The Hanford SNF Project has already processed about 90 MCOs loaded with SNF elements from the K-West Basin. However, to minimize the risk of missing a critical Tri-Party Agreement milestone for Hanford cleanup, the project also is looking at steps to further accelerate the current schedule through process optimization. Delays in completion of the project increase both the project lifecycle cost and the risk of exposing the public, workers, and the environment to radioactive material that could be released through potential leaks.

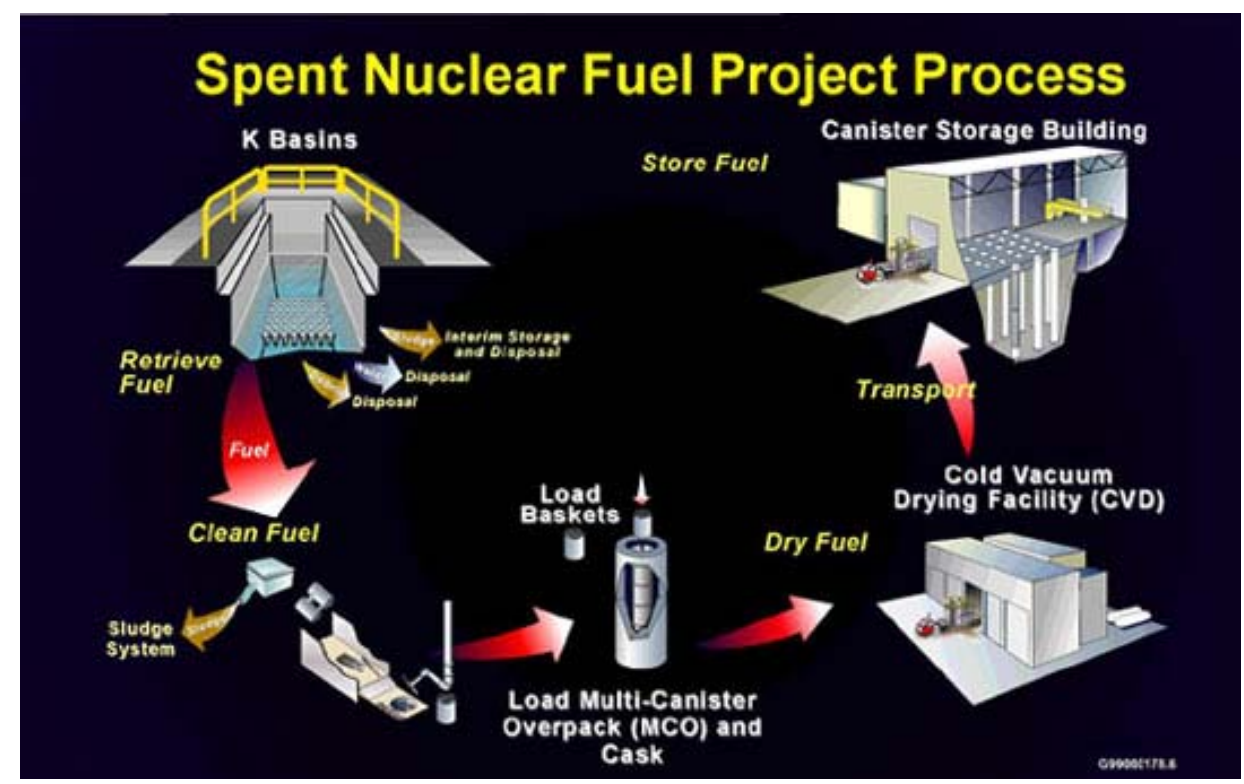

Figure 1.1. Hanford K-Basin SNF Project Process Flow Diagram

The optimization steps may, therefore, have a positive impact on the safety basis for treating the SNF, and the chemical reactivity could be a major factor in optimizing the process. The chemical reactivity of

\footnotetext{
${ }^{a}$ Fuel for use in the N-Reactor was fabricated from a uranium alloy that was co-extruded with a Zircaloy-2 cladding. Zircaloy- 2 end caps were brazed to the ends of the fuel elements to seal the uranium inside the cladding.
} 
the fuel is influenced by several factors, such as the amount of hydride contained in the fuel and the exposed fuel surface area available for reaction. To manage and simplify the combined effect of these other factors, the project developed a dimensionless term called the "enhancement factor" that relates the potential reactivity of the water-stored N-Reactor spent fuel to that of literature-reported oxidation rates for unirradiated uranium metal. The spent-fuel reactivity enhancement factor that was empirically derived was 22, and this conservative value was used to develop the fuel drying process to assure that the operations were sufficiently conservative, i.e., to preclude any chance for a runaway chemical reaction during drying.

Before making any changes to improve on process throughput, the impacts of the changes on the process safety basis must be evaluated and approved before implementation. Consequently, the impact of the K-Basin SNF reactivity must be re-evaluated to develop a technically sound prediction of the CVD process. The analyses should include the oxidation-rate constant and the exposed surface area of the SNF to demonstrate that the reactivity enhancement factor previously used to analyze the CVD process remains conservative. This report describes a re-examination of the laboratory testing data for the KBasin SNF to determine whether the level of conservatism can accommodate the optimization steps for the CVD process in relation to chemical reactivity of the SNF. The process will include re-evaluation of the SNF reaction-rate constant to determine the best value applicable to the corroded K-Basin SNF material, and the established rate constant will be used to determine the reactive surface areas of damaged/corroded K-Basin SNF elements. The developed analytical method will be extended to calculate the exposed uranium surface areas of the SNF elements loaded into the MCOs with available monitoring data. 


\subsection{SNF Oxidation In Moist Atmospheres}

Storing the metallic N-Reactor SNF elements in the water-filled K-Basins has resulted in severe corrosion of the exposed uranium cores due to breaches in the Zircaloy cladding. The corrosion reactions include

$$
\begin{aligned}
& \mathrm{U}+(2+\mathrm{x}) \mathrm{H}_{2} \mathrm{O}=\mathrm{UO}_{2+\mathrm{x}}+(2+\mathrm{x}) \mathrm{H}_{2} \\
& 2 \mathrm{U}+3 \mathrm{H}_{2}=2 \mathrm{UH}_{3} \\
& 2 \mathrm{UH}_{3}+4 \mathrm{H}_{2} \mathrm{O}=2 \mathrm{UO}_{2}+7 \mathrm{H}_{2}
\end{aligned}
$$

These have generated an SNF material that could have significant changes in its oxidation kinetic properties. Two factors that could affect the oxidation kinetics of the corroded material are

1) increased surface area due to surface roughness and

2) the generation of uranium hydride inclusions in the uranium matrix, i.e., reaction (2.2).

Consequently, the SNF characterization strategy at Hanford included experimental studies to determine the oxidation behavior of the corroded K-Basin SNF samples in different atmospheres using a furnace tube and thermo-gravimetric (TGA) systems (Abrefah et al. 1998a; Abrefah et al. 1998b; Abrefah et al. 1999). The moist-atmosphere study is reviewed in this report to establish the K-Basin SNF reaction-rate constant.

\subsection{Moist-Air Oxidation}

A review of metallic uranium oxidation behavior in moist air by Pearce et al. (Pearce 1988) concluded that the oxidation rate of irradiated, and hence swollen, uranium was independent of the partial pressure of water vapor. However, because the oxidation behavior of the damaged/corroded SNF metallic uranium in dry air (Abrefah et al. 1998a) showed some tendency towards a higher oxidation rate at lower temperatures, a few tests were performed in a moist-air atmosphere using the thermo-gravimetric system (Abrefah et al. 1998b). The linear oxidation rates for three SNF material runs are compared to the rate equations from a report by Pearce et al. (Pearce 1988) in Figure 2.1 for moist- and dry-air atmospheres.

The limited SNF reaction rates in moist air are well bounded by the rate equations of Pearce et al. (Pearce et al. 1988). Figure 2.1 shows that the oxidation rate for the unirradiated uranium in moist air is higher than the measured rates for K-Basin SNF material. Also, the moist-air rates for both the SNF and the unirradiated uranium are higher than the rates in dry air for unirradiated uranium. This observed enhanced reactivity for metallic uranium in a moist atmosphere has been ascribed to the formation of a transitory uranium hydride phase (Equation 2.2) ahead of the oxidation front (Bennet 1975). The corroded SNF material did not show additional reactivity enhancement due to potential matrix hydride inclusions resulting from the water storage. This suggests that the in situ formation of uranium hydride

during the sample oxidation test may overshadow any effect of the small matrix precipitate of hydride as result of the corrosion process during storage. 


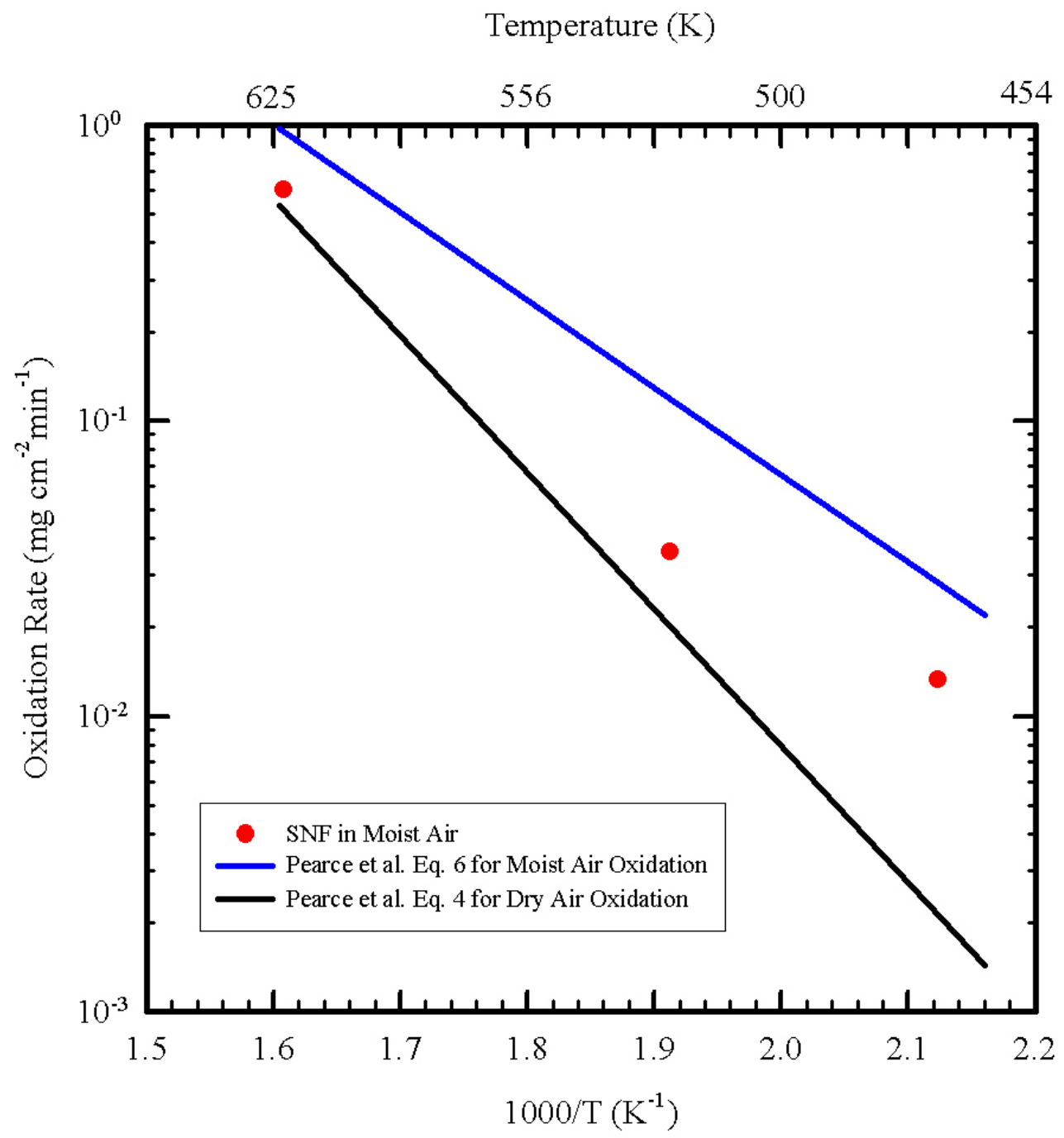

Figure 2.1. Comparison of the Oxidation Rate for N-Reactor Fuel in Moist Air with the Calculated Rates (Equations 6 and 4) of Pearce et al. (Pearce et al. 1988) for Unirradiated Uranium

\subsection{Moist-Inert Oxidation}

An experimental study was performed in a moist helium-gas atmosphere to determine the reactivity of the corroded K-Basin SNF material for comparison with data available in the open literature for metallic uranium (Pearce 1989). The measured SNF oxidation rates and the literature data were all normalized to the square root of the water-vapor pressure in $\mathrm{kPa}$ for comparison. Results of the calculations are shown in Figure 2.2 as an Arrhenius plot. The rate constant for K-West Basin SNF oxidation in the moist helium-gas mixture was determined by a linear regression fit to the SNF data points labeled as complete oxidation-rate data (Abrefah and Sell 1999) (filled squares) using the Arrhenius expression

$$
\mathrm{k}=\mathrm{k}_{0} \exp \left(-\mathrm{E}_{\mathrm{a}} / \mathrm{RT}\right)
$$


where $\mathrm{k}_{0}$ is the pre-exponential factor, $\mathrm{E}_{\mathrm{a}}$ is the activation energy, $\mathrm{R}$ is the gas constant, and $\mathrm{T}$ is the absolute temperature in Kelvin. The regression analysis yielded a rate constant for K-West Basin SNF uranium as

$$
k=4.53 \times 10^{5} \exp (-13.3 / R T) m g / \mathrm{cm}^{2} / \mathrm{hr} / \sqrt{\mathrm{kPa}}
$$

where the activation energy is in $\mathrm{kcal} / \mathrm{mole}$.

The limited data show that the K-West Basin SNF oxidation rates in a moist-helium atmosphere fall below the lower boundary of the $95 \%$ prediction-interval (Figure 2.2) line of the published data. The lowering of the measured oxidation rates for the K-West Basin SNF may be due to the well-known effect of oxygen poisoning on uranium moisture reactions. Experimentally, the oxygen poisoning is very difficult to control and measure accurately since it only takes a few ppm levels. The source of oxygen could be air in-leakage into the TGA system during the experiment. Nonetheless, the calculated SNF-rate constant (Equation 2.5) from the measured data could be the best value for the SNF material.

Temperature (K)

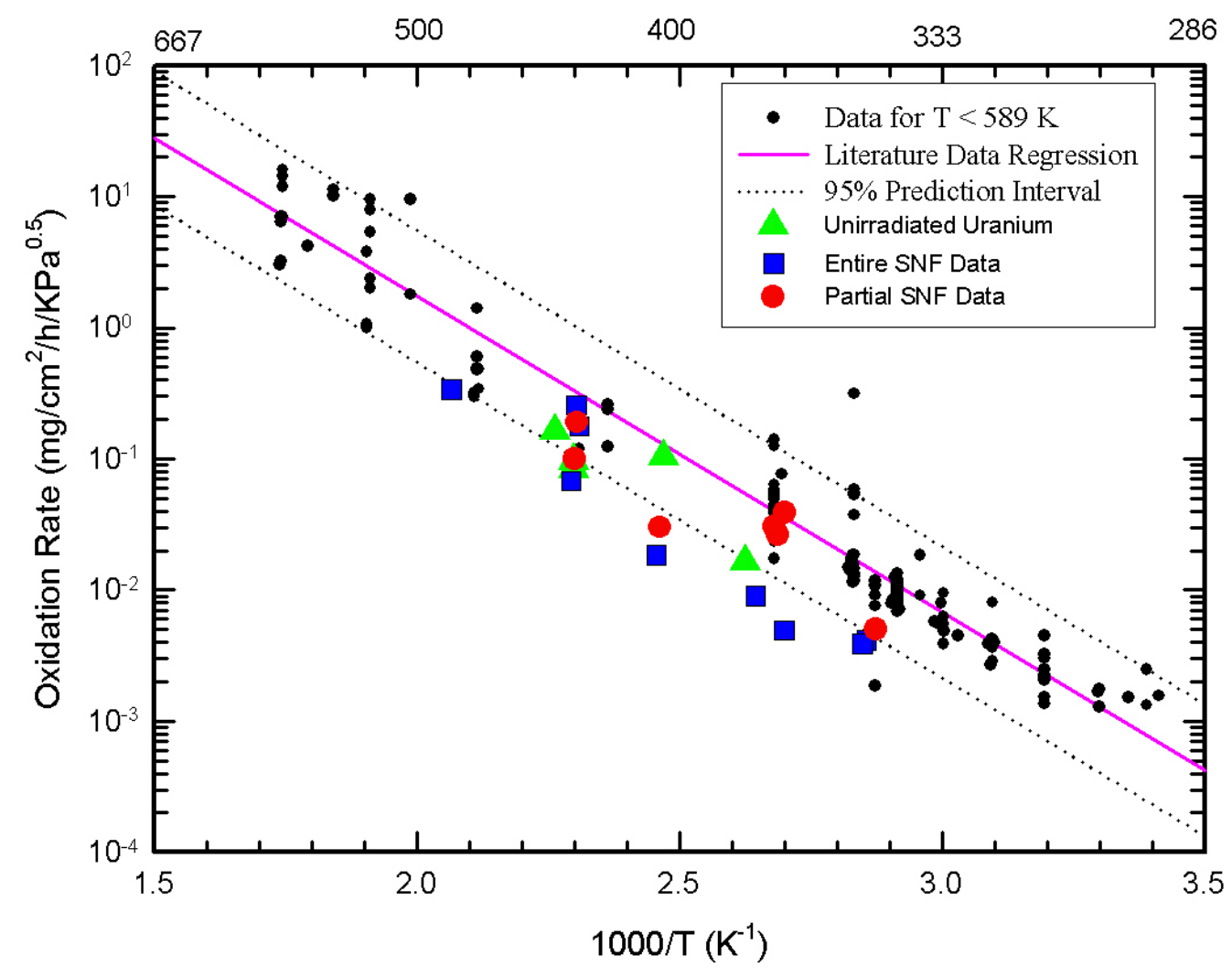

Figure 2.2. Comparison of N-Reactor Fuel Material Oxidation Rate with the Published Data for Uranium in Oxygen-Free Water Vapor 


\subsection{Whole Fuel Element Testing}

The whole-element furnace test setup was a laboratory-scale system designed to determine the drying characteristics of eight SNF elements taken from K-West Basin. Six of these elements had varying degrees of corrosion damage, including a broken piece and two undamaged elements. The laboratoryscale drying process included the CVD and hot-vacuum drying (HVD) processes. A detailed description of the experimental system has been reported by Ritter et al. (Ritter et al. 1998), and the experimental results for all the K-Basin SNF elements have been reported (Klinger et al. 1998; Klinger et al. 1999; Oliver et al. 1998; Oliver et al. 1999a; Oliver et al. 1999b; Oliver et al. 1999c) and will not be discussed further in this report. The data generated by the experimental method included off-gas species monitoring using both gas chromatography (GC) and a quadrupole mass spectrometer. The species recorded included the hydrogen generation rate resulting from a moisture reaction with the exposed uranium surface, water-vapor pressure, and released fission gases, such as krypton and xenon. The fission gas release was due to oxidation of the uranium matrix. A typical result for drying a damaged/corroded SNF element 5744U (Run 4) showing hydrogen evolution, water vapor pressure, and temperature history is shown in Figure 3.1, and the severity of the corrosion damage to that element is shown in the photograph of Figure 3.2.

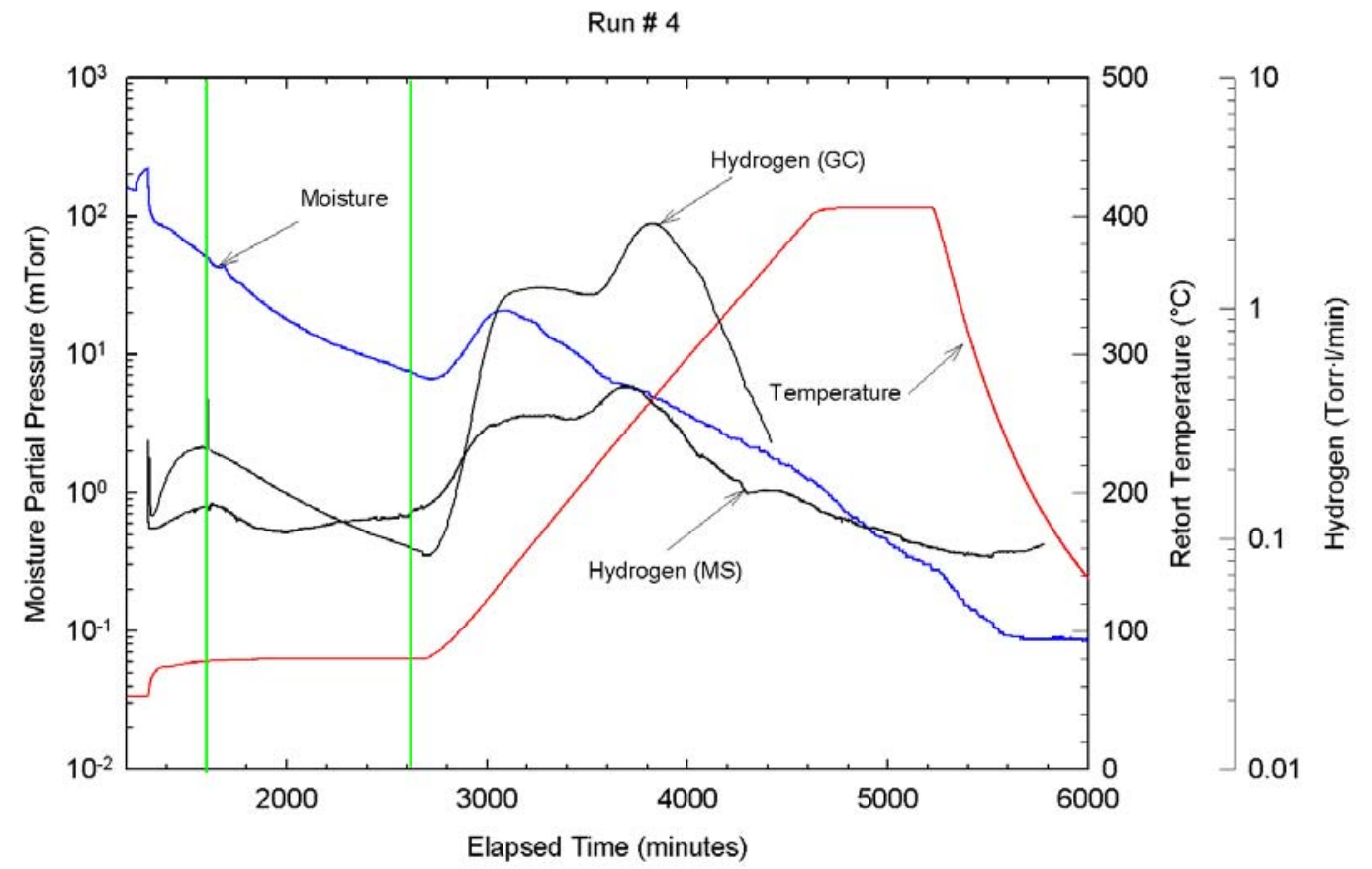

Figure 3.1. Drying Results for a Corroded SNF Element-5744U at Different Temperatures

\subsection{Fuel-Element Surface-Area Estimate}

The hydrogen generation rate at a selected region of the SNF drying data was used together with the known reaction-rate constant for the corroded K-Basin SNF material (Equation 2.5) in this report to calculate the exposed reactive surface area. 


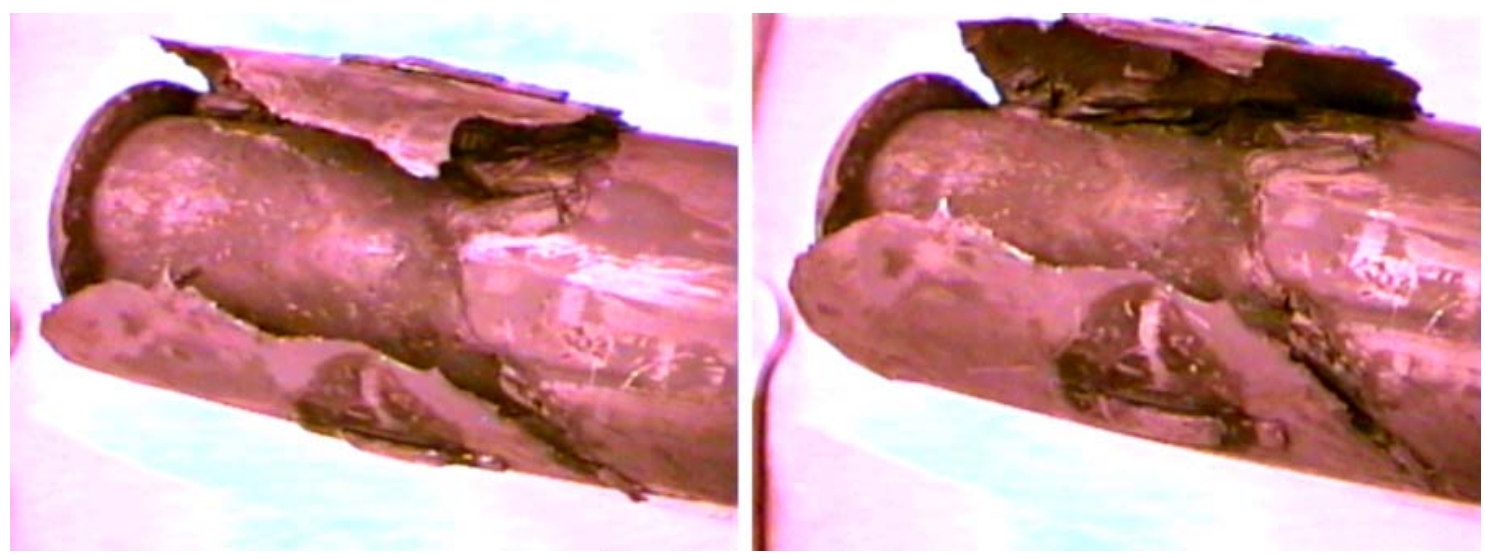

Figure 3.2. Corroded/Damaged SNF Element 5744U

The oxidation-rate studies discussed in the previous section for the SNF have established that in moist atmospheres, including oxygen-free water vapor, the reactivity of the degraded/corroded SNF metallic uranium is well bounded by the data published in the literature. Thus, reliability is established for either the measured or the literature-determined rate constant to be used in chemical reactivity calculations involving the corroded SNF material. The surface areas for the degraded SNF elements dried in the whole-element-furnace system were then estimated using the hydrogen-generation-rate data from the reaction

$$
\mathrm{U}+2 \mathrm{H}_{2} \mathrm{O}=\mathrm{UO}_{2}+2 \mathrm{H}_{2}
$$

The measured hydrogen generation rates at the constant-temperature region in Figure 3.1 were used in the analysis. The oxidation-rate equation (2.5) for the limited SNF testing data was used in these calculations. The water-vapor normalized rate equation is defined as

$$
\mathrm{k}(\mathrm{T})=\Delta \mathrm{W} / \mathrm{A} / \sqrt{ } \mathrm{P}_{\mathrm{H} 2 \mathrm{O}}(\mathrm{kPa})
$$

where $\Delta \mathrm{W}$ is the weight-gain rate due to oxygen uptake, $\mathrm{A}$ is the exposed surface area, and $\mathrm{P}$ is the vapor pressure in $\mathrm{kPa}$. Rearranging Equation 3.2 gives the following explicit expression for the surface area:

$$
\mathrm{A}=\Delta \mathrm{W} / \mathrm{k}(\mathrm{T}) / \sqrt{ } \mathrm{P}_{\mathrm{H} 2 \mathrm{O}}(\mathrm{kPa})
$$

Equation 3.1 relates the oxygen pick-up rate to the hydrogen generation rate. Using the molar relation from Equation 3.1 to covert Equation 3.3 to an expression relating to the hydrogen generation rate yields

$$
\mathrm{A}=8 \Delta \mathrm{h} / \mathrm{k}(\mathrm{T}) / \sqrt{ } \mathrm{P}_{\mathrm{H} 2 \mathrm{O}}(\mathrm{kPa})
$$

where $8=\{32 / 8\}$ is the molecular weight ratio of oxygen to hydrogen, $\Delta \mathrm{h}$ is hydrogen generation rate in $\mathrm{mg} / \mathrm{min}, \mathrm{k}(\mathrm{T})$ is the rate constant at absolute temperature $\mathrm{T}$ in $\mathrm{mg} / \mathrm{cm}^{2} / \mathrm{min} /{ }_{\mathrm{kPa}}$, and $\mathrm{P}_{\mathrm{H} 2 \mathrm{O}}$ is the vapor 
pressure in $\mathrm{kPa}$. For example, after an elapsed time of $1600 \mathrm{~min}$ in Run 4 (Figure 3.1), the following parameters were measured:

- Temperature, $\mathrm{T}=348 \mathrm{~K}$

- Vapor pressure $=5.77 \times 10^{-3} \mathrm{kPa}$

- Hydrogen generation rate, $\Delta \mathrm{h}=0.0259 \mathrm{mg} / \mathrm{min}$

- $\mathrm{k}(348 \mathrm{~K})=3.347 \times 10^{-5} \mathrm{mg} / \mathrm{cm}^{2} / \mathrm{min} / ل_{\mathrm{kPa}}$ using Equation 2.5

Substituting the above data into Equation (3.4) yielded a surface area of $8.13 \mathrm{~m}^{2}$. Similar calculations were performed for all the data points in the region between the two vertical lines shown in Figure 3.1, and the process was repeated for the drying curves of the other SNF elements (shown in Appendix A). Averaged surface areas for the SNF elements were computed from the data points, and the outcome of the calculations are listed in Column 3 of Table 3.1.

The geometric surface area of a clean, broken N-Reactor outer-fuel element was calculated using the geometrical dimensions to be approximately $0.0015 \mathrm{~m}^{2}$. The estimated surface area of the broken piece of N-Reactor element using the hydrogen-generation-rate data of the whole-element furnace testing, i.e., Run \#3, and the SNF-rate Equation 2.5 gave a value of $0.00175 \mathrm{~m}^{2}$. The degree of agreement between these two methods is very good and therefore supports the accuracy of using the furnace data to determine the reactive surface areas of all the SNF elements that were dried in the laboratory hot-cell furnace. The agreement also confirms the accuracy of the SNF reaction-rate constant. i.e., Equation 2.5.

The Hanford SNF project made the decision to use the averaged literature-rate constant in all analyses involving the CVD process. Hence, for comparison, the surface-area calculations were repeated using the literature-rate equation, klit (Equation 3.5), derived from the literature data and reported by Pajunen (Pajunen 1999).

$$
\mathrm{k}(\mathrm{T})=2.14 \times 10^{4} \exp (-9.81 / \mathrm{RT}) \mathrm{mg} / \mathrm{hr} / \mathrm{cm}^{2} / \sqrt{ } \mathrm{kPa}
$$

where the activation energy is in $\mathrm{kcal} / \mathrm{mole}$. Results of the calculations using the literature-rate, Equation 3.5, are listed in Column 4 of Table 3.1. 
Table 3.1. Surface Areas of Damaged K-Basin Spent Fuel Elements

\begin{tabular}{|c|c|c|c|c|c|}
\hline \multirow[b]{2}{*}{ Run \# } & \multirow[b]{2}{*}{ Element ID } & \multicolumn{2}{|c|}{ Estimated Area $\left(\mathrm{m}^{2}\right)$} & \multirow[b]{2}{*}{ Comments on Damage } & \multirow[b]{2}{*}{ Reference } \\
\hline & & Based on $\mathbf{k}_{\mathrm{SNF}}$ & Based on $k_{\text {lit }}$ & & \\
\hline 3 & 0309M & 0.0018 & 0.0002 & Broken piece & $\begin{array}{l}\text { Oliver et al. } \\
(1998)\end{array}$ \\
\hline 4 & $5744 \mathrm{U}$ & 8.1 & 1.1 & Highly corroded at one end & $\begin{array}{l}\text { Klinger } \\
\text { et al. (1998) }\end{array}$ \\
\hline 5 & $6603 \mathrm{M}$ & 2.1 & 0.29 & Split open at one end with extensive corrosion & $\begin{array}{l}\text { Klinger } \\
\text { et al. (1999) }\end{array}$ \\
\hline 6 & $1164 \mathrm{M}$ & 6.2 & 0.85 & Severely cracked element & $\begin{array}{l}\text { Oliver et al. } \\
(1999 \mathrm{a})\end{array}$ \\
\hline 7 & $2660 \mathrm{M}$ & 3.0 & 0.41 & Severe corrosion at one end with split cladding & $\begin{array}{l}\text { Oliver et al. } \\
(1999 b)\end{array}$ \\
\hline $8 a^{*}$ & \multirow[t]{2}{*}{$6153 \mathrm{M}$} & 5.2 & 0.71 & \multirow{2}{*}{$\begin{array}{l}\text { Severe corrosion damage at one end and less at } \\
\text { the other }\end{array}$} & \multirow{2}{*}{$\begin{array}{l}\text { Oliver et al } \\
(1999 c)\end{array}$} \\
\hline $8 \mathrm{~b}^{* *}$ & & 3.4 & 0.46 & & \\
\hline
\end{tabular}

The literature-rate constant (Equation 3.5), on the other hand, underestimated the area for the broken element by a factor of about 7 . Notwithstanding the accuracy of the hydrogen generation-rate data, the literature rate is not yielding good surface-area results, suggesting that the lower rate measured by Abrefah and Sell (1999) may be the best reaction-rate constant for the corroded/damaged N-Reactor metallic uranium in an atmosphere containing oxygen-free water vapor.

The SNF elements that were used in the drying study were carefully handled such that all the particulates from the in-storage corrosion process were part of the test sample. Therefore, for the severely damaged elements, the SNF corrosion particulates should contribute significantly to the estimated surface areas described in Table 3.1. Even with the contribution from the small corrosion particulates, the most severely damaged SNF element in Table 3.1 (Run 4) gave an average surface area of about $1.1 \mathrm{~m}^{2}$ (based on the literature-rate constant).

The Hanford SNF project estimated bounding surface areas for various loading configurations of the MCO using the visual inspection data and the literature-rate constant together with a reactivity enhancement factor of 22 to account for such effects as surface roughness and probable matrix disruption resulting from the corrosion process. The bounding SNF surface area for a typical MCO with two scrap baskets and loaded with 240 elements is $12 \mathrm{~m}^{2}$. About $4.5 \mathrm{~m}^{2}$ of the area is attributed to the scrap basket that should have a total of 39 severely corroded elements.

To be consistent with the SNF project, the literature-rate constant is used in the subsequent calculations. The analysis performed by the project can be redone using the elemental surface areas listed in Table 3.1. For such calculations, the bounding surface area of $12 \mathrm{~m}^{2}$ should be multiplied by the factor 22 (the reactivity enhancement factor used in the original calculation by the project) to determine the number of SNF elements needed to exceed the safety conditions. For example, in order for the scrap basket to exceed the bounding safety calculations, it has to be loaded with $4.5 \times 22 / 1.1$ (=90) of severely corroded SNF Element-5744U (Run 4). The result is a factor of 2.3 lower than the calculated loading of only 39 . This simplified calculation shows the benefit of not using the reactivity enhancement factor, but 
rather to do calculations involving the safety cases for the CVD process and to use the measured surface areas and rate constant for the N-Reactor SNF material.

Before using any of the information in Table 3.1 in support of the SNF project, a much-detailed safety analysis has to be performed with the literature-rate equation and the estimated SNF surface areas in Table 3.1 but without the enhancement factor to verify the above simple calculation. The converse supposition could also be made to indicate that the Hanford SNF Project could use a safety factor of 9.5 and still remain within the safety boundary of the current process even if the entire scrap basket is loaded with only the severely corroded SNF element 5744U in Table 3.1 (see SNF photograph in Figure A.2 of Appendix A).

However, the reactivity enhancement factor should always be differentiated from the system-design safety factor in the analyses. The design safety factor should be influenced by the statistical spread of the known reactivity data.

There is an additional safety feature built into the surface areas listed in Table 3.1. The MCOs are loaded with SNF elements that have been subjected to a cleaning process (Figure 1.1) in the primary cleaning machine (PCM). The cleaning process in the PCM separates the corrosion particulates from the SNF elements, which are not being loaded into the MCOs. Since the corrosion particulates have a major contribution effect to the surface areas determined in Table 3.1, any process of excluding the particulates would significantly reduce the reactive surface areas of those elements and hence limit the reactivity of the SNF elements. Therefore, any analyses using the areas in Table 3.1 will result in a conservative estimate for the reactivity of these corroded SNF elements. 


\subsection{Surface Area of SNF Elements in MCO}

The calculation method in Section 3 was applied to the data from the CVD process of drying the SNF elements in the MCO for the interim dry-storage facility. The final step for treating the degraded NReactor SNF for an interim dry storage involves removing "free" water in the packaged MCO using the CVD process. The process entails 14 sequences comprised of several steps. The CVD process involves heating the contents of the MCO using a water jacket and helium atmosphere for better thermal conductivity and removing vaporized water using a condenser plus a vacuum pump. During a limited set of steps in the drying process, a residual gas analyzer (RGA) is connected to the CVD Facility to monitor the gaseous species downstream. The gases monitored by the RGA include

- hydrogen generated by exposed uranium reaction with the moisture atmosphere

- gases in the air, i.e., nitrogen, oxygen, carbon dioxide, and argon, due to inleakage

- fission gases, i.e., krypton and xenon, evolution

- hydrocarbons from possible reaction with the carbides in the N-Reactor fuel.

These gases were analyzed together with the process data for the MCO temperature and pressure to provide best estimates of the damaged SNF-exposed total area using the same method and equations used in Section 3. Summary information for each MCO analyzed is shown in Appendix B. The segments of data, i.e. both the RGA and process, selected for the analyses are plotted for each MCO and are also shown in Appendix B. The results of the calculation for the first 9 MCOs (excluding MCO \#4 that was processed without the RGA monitoring) are listed in Table 4.1.

Table 4.1. Total Exposed Uranium Surface Reactive Area of MCO Elements

\begin{tabular}{|c|c|c|c|c|}
\hline MCO ID (\#) & Ave. Temp. (K) & Av. Total Press. (Pa) & $\begin{array}{l}\mathrm{H}_{2} / \mathrm{H}_{2} \mathrm{O} \text { Ratio } \\
\end{array}$ & Reactive Area $\left(\mathrm{m}^{2}\right)$ \\
\hline $36(1)$ & 318 & 61.78 & 0.001 & $0.13 \pm 0.01$ \\
\hline $35(2)$ & 316 & 68.30 & 0.023 & $2.41 \pm 0.14$ \\
\hline $34(3)$ & 318 & 60.11 & 0.098 & $4.97 \pm 0.66$ \\
\hline $32(5)$ & 318 & 60.20 & 0.043 & $1.00 \pm 0.09$ \\
\hline $69(6)$ & 318 & 68.09 & 0.020 & $1.81 \pm 0.13$ \\
\hline $82(7)$ & 318 & --- & 0.021 & $1.76 \pm 0.25$ \\
\hline $89(8)$ & 318 & 58.34 & 0.041 & $1.61 \pm 0.10$ \\
\hline $88(9)$ & 318 & 82.65 & 0.017 & $1.10 \pm 0.13$ \\
\hline
\end{tabular}

MCO-36 was loaded with undamaged SNF elements and should be the baseline value for these calculations; that is, the value of $0.13 \mathrm{~m}^{2}$ for MCO-36 should be considered as the zero limit of the analysis. The total reactive surface areas in Table 4.1 show that MCO-36 with undamaged SNF elements has a total exposed area that is about an order of magnitude lower than the remaining MCOs with different damaged SNF elements. Also, the total reactive surface areas for the MCOs with the corroded SNF elements are all below the safety bounding value of $12 \mathrm{~m}^{2}$, even though the SNF-rate constant (Equation 2.5) was used in the calculations. Additionally, the enhancement factor of 22 used by the 
project to establish the 12- $\mathrm{m}^{2}$-area boundary was not accounted for in these analyses. Thus, these results support the conservatism built into the CVD process.

Another observation about the data listed in Table 4.1 is the correlation between the $\mathrm{H}_{2} / \mathrm{H}_{2} \mathrm{O}$ ratios and the exposed reactive surface areas. Generally, a higher $\mathrm{H}_{2} / \mathrm{H}_{2} \mathrm{O}$ ratio yielded a higher reactive surface area. If this trend is proven for several MCOs, it could be used as an indicator for predicting higher surface areas in the MCOs without the complete analyses of the data as was performed in this report. That will be a very useful tool for a project such as the Hanford Spent Nuclear Fuel Project.

Additionally, the analyses performed also generated other useful information for the CVD process that includes the following (see the summary tables in Appendix B):

- water-removal rate

- air-inleakage rate

- prediction of gas-generation rate for the sealed MCO during the early years in storage.

\subsection{SNF Crumbling Effect}

The effect of the SNF crumbling due to the corrosion damage to the fuel elements has not been a factor influencing the surface areas in the MCOs analyzed. The particulates generated by washing the corroded SNF elements in the PCM have not been loaded into any packaged MCO. The characteristics of particulates resulting from the PCM treatment are shown in Figure 4.1. They ranged in small sizes, i.e., less than a micron, to pieces of fuel.

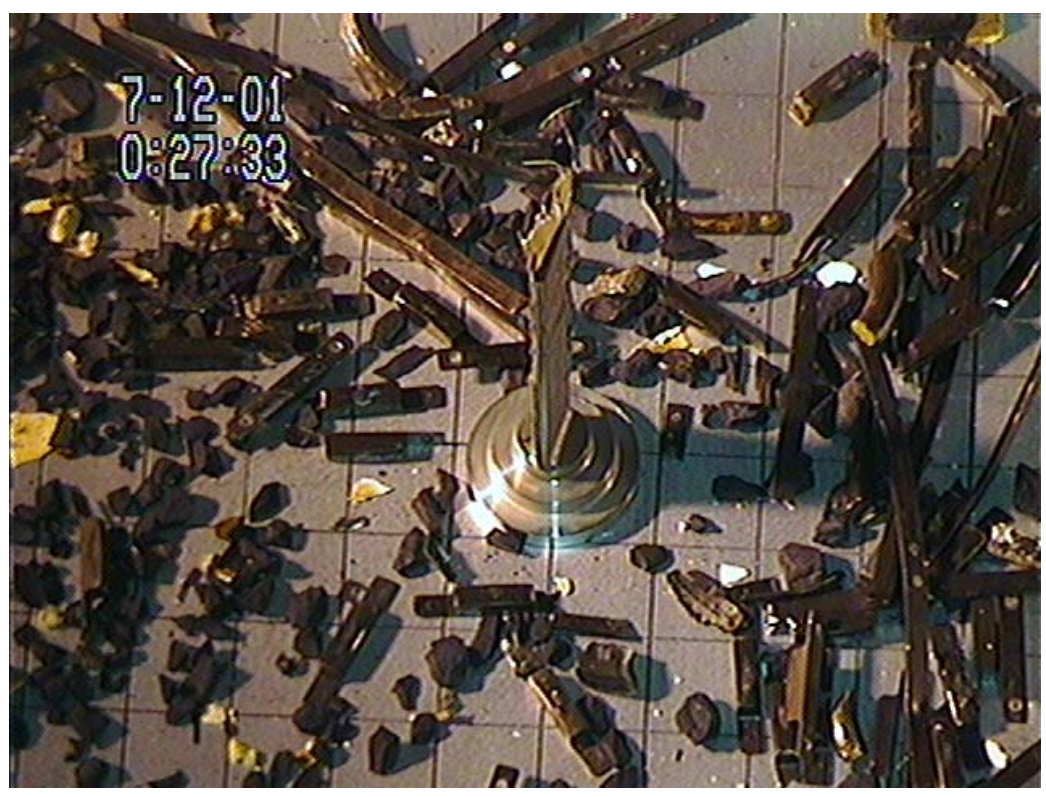

Figure 4.1. SNF Particulates and Scrap Generated by Washing Corroded Elements in the PCM 
The general characteristics of the particulates and surface areas have been analyzed and reported by Kuhn et al. (2001). The fuel particulates, in particular, are similar to the crumbled products generated during oxidation of corroded sample pieces in the laboratory and reported by Abrefah and Sell (1999). The particulates will significantly influence the exposed surface areas if they are loaded into the MCOs. 


\subsection{Conclusions}

The only experimental evidence of enhanced reactivity of the degraded/corroded SNF metallic uranium is associated with a dry-air atmosphere. The two tests conducted under moist conditions, i.e., moist air and moist-inert gas, showed no significant difference between the measured data and the data published in the literature for unirradiated metallic uranium. Based on these results, we do not believe that the rate constant for the N-Reactor fuel material (the literature average) should be multiplied by a reactive enhancement factor when analyzing SNF material in moist atmospheres. A safety factor could be applied to the design of the process, but that approach should be differentiated from the use of a reactivity-enhancement factor.

The reactive surface area was another parameter that was very difficult to predict, given the methods that were initially used to determine the best estimate. Based on the hydrogen-generation rate from the NReactor SNF, the reactive surface areas of elements with different degrees of damage were accurately determined. The sample batch analyzed was very limited in scope, but the nature and degree of damage observed in these spent-fuel elements could be representative of a large fraction of the K-West Basin SNF inventory. The estimated areas for these elements could therefore be used by the Hanford SNF Project to provide realistic bounding surface areas for various MCO loading configurations.

Based on the developed method for the single-fuel elements, the RGA data for the first batch of MCOs was analyzed to provide the exposed uranium-surface reactive areas for SNF elements loaded into these sealed containers. The total exposed surface area in each MCO is below the bounding project conditions, and the method is capable of predicting a very low surface area for the first MCO, i.e., MCO36 , that was loaded with undamaged SNF elements. Thus, providing a proofing method to calculate surface areas of the corroded elements loaded into each MCO, provided that an RGA is used to monitor the downstream gas species during the CVD drying process.

The calculated exposed surface areas in the sealed MCOs provide a basis for the database to be able to predict the gas generation rate within each MCO during the early years of storage that can be attributed to water/uranium reaction. 


\subsection{References}

Abrefah J, HC Buchanan, WM Gerry, WJ Gray, and SC Marschman. 1998a. Dry Air Oxidation Kinetics of K-Basin Spent Nuclear Fuel, PNNL-11786, Pacific Northwest National Laboratory, Richland, WA.

Abrefah J, HC Buchanan, and SC Marschman. 1998b. Oxidation Rate of K-Basin Spent Nuclear Fuel in Moist Air, PNNL-11844, Pacific Northwest National Laboratory, Richland, WA.

Abrefah J, and RL Sell. 1999. Oxidation of K-West Basin Spent Nuclear Fuel In Moist Helium Atmosphere, PNNL-12167, Pacific Northwest National Laboratory, Richland, WA.

Bennet MJ, BL Myatt, DRV Silvester, and JE Antill. 1975. "The Oxidation Behaviour of Uranium in Air at $50-300^{\circ}$ C." J. of Nucl. Mater. 57:221.

Klinger GS, BM Oliver, J Abrefah, SC Marschman, PJ MacFarlan, and GA Ritter. 1998. Drying Results of K-Basin Fuel Element $5744 U$ (Run 4), PNNL-11821, Pacific Northwest National Laboratory, Richland, WA.

Klinger GS, BM Oliver, SC Marschman, J Abrefah, LR Greenwood, PJ MacFarlan, and GA Ritter. 1999. Drying Results of K-Basin Fuel Element 6603M (Run 5), PNNL-11841, Pacific Northwest National Laboratory, Richland, WA.

Kuhn WL, J Abrefah, AL Pitner, M Plys, JP Sloughter, JC Wiborg, and DW Damschen. 2001. Technical Review of the Characteristics of Spent Nuclear Fuel Scrap, PNNL-13751, Pacific Northwest National Laboratory, Richland, WA.

Oliver BM, GS Klinger, J Abrefah, SC Marschman, PJ MacFarlan, and GA Ritter. 1998. Drying Results of K-Basin Fuel Element 0309M (Run 3), PNNL-11820, Pacific Northwest National Laboratory, Richland, WA.

Oliver BM, GS Klinger, J Abrefah, SC Marschman, PJ MacFarlan, and GA Ritter. 1999a. Drying Results of K-Basin Fuel Element 6603M (Run 6), PNNL-11896, Pacific Northwest National Laboratory, Richland, WA.

Oliver BM, GS Klinger, J Abrefah, SC Marschman, PJ MacFarlan, and GA Ritter. 1999b. Drying Results of K-Basin Fuel Element 2660M (Run 7), PNNL-11897, Pacific Northwest National Laboratory, Richland, WA.

Oliver BM, GS Klinger, J Abrefah, SC Marschman, PJ MacFarlan, and GA Ritter. 1999c. Drying Results of K-Basin Fuel Element 6153 U (Run 8), PNNL-11969, Pacific Northwest National Laboratory, Richland, WA.

Pajunen AL. 1999. Uranium Oxidation Rate Summary for Spent Nuclear Fuel Project, HNF-4165 Rev 0, Duke Engineering and Services Hanford, Inc., Richland, WA. 
Pearce RJ, MJ Bennett, and JB Price. 1988. "Oxidation of irradiated uranium in moist air." Nucl. Ener. 27(5):305.

Pearce RJ. 1989. A Review of the Rates of Reaction of Unirradiated Uranium in Gaseous Atmosphere. RD/B/6231/R86, Central Electric Generating Board, Berkeley Nuclear Laboratories, UK.

Ritter GA, SC Marschman, PJ MacFarlan, and DA King. 1998. System Design Description for the Whole Element Furnace Testing System. PNNL-11807, Pacific Northwest National Laboratory, Richland, WA. 


\section{Appendix A}

\section{Whole-Element Testing Results}




\section{Appendix A: Whole-Element Testing Results}

\section{Figures}

A.1. Hydrogen Generation Rate (left) for the Broken SNF Element 0309M (right) at Different Temperatures.

A.2. Hydrogen Generation Rate (left) for the Corroded SNF Element 5744U (right) at Different Temperatures.

A.3. Hydrogen Generation Rate (left) for the Corroded SNF Element 6603M (right) at Different Temperatures.

A.4. Hydrogen Generation Rate (left) for the Cracked SNF Element 1164M (right) at Different Temperatures

A.5. Hydrogen Generation Rate (left) for the Cracked and Corroded SNF Element 2660M (right) at Different Temperatures

A.6. Hydrogen Generation Rate (left) for the Cracked and Corroded SNF Element 6153U (right) at Different Temperatures 


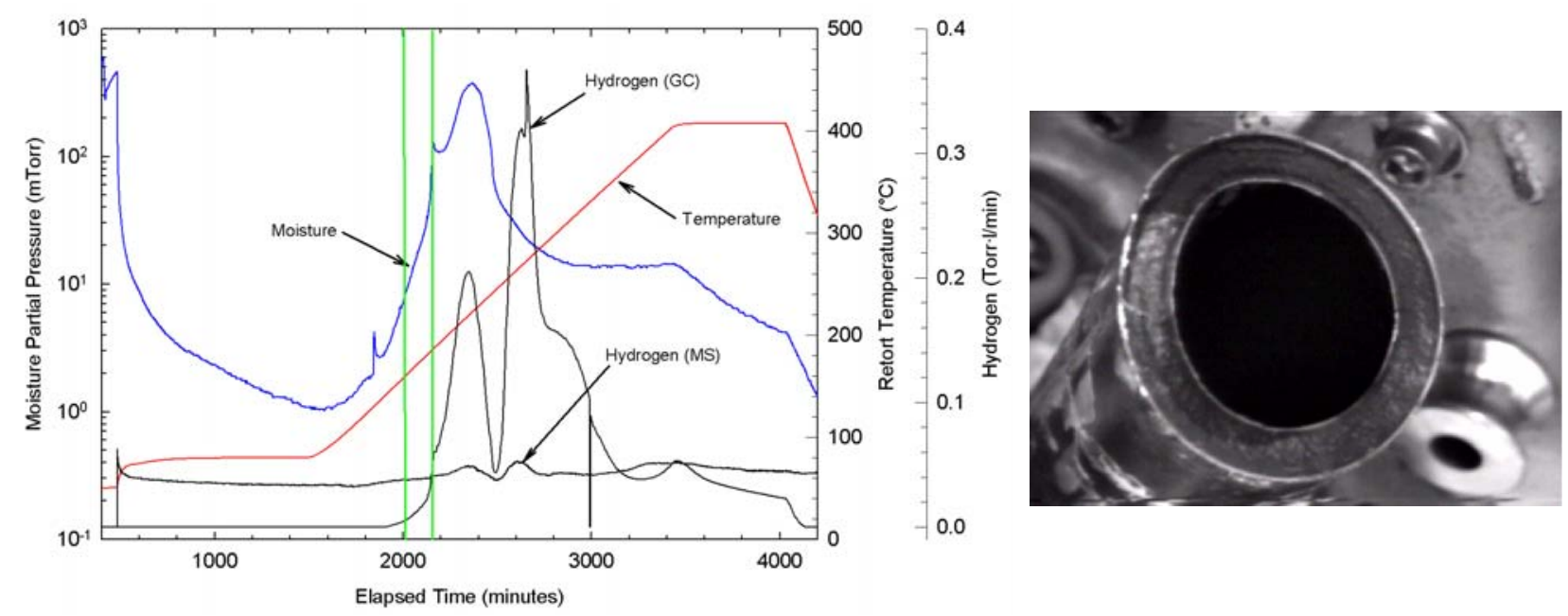

Figure A.1. Hydrogen Generation Rate (left) for the Broken SNF Element 0309M (right) at Different Temperatures. The two green lines border the analyzed region

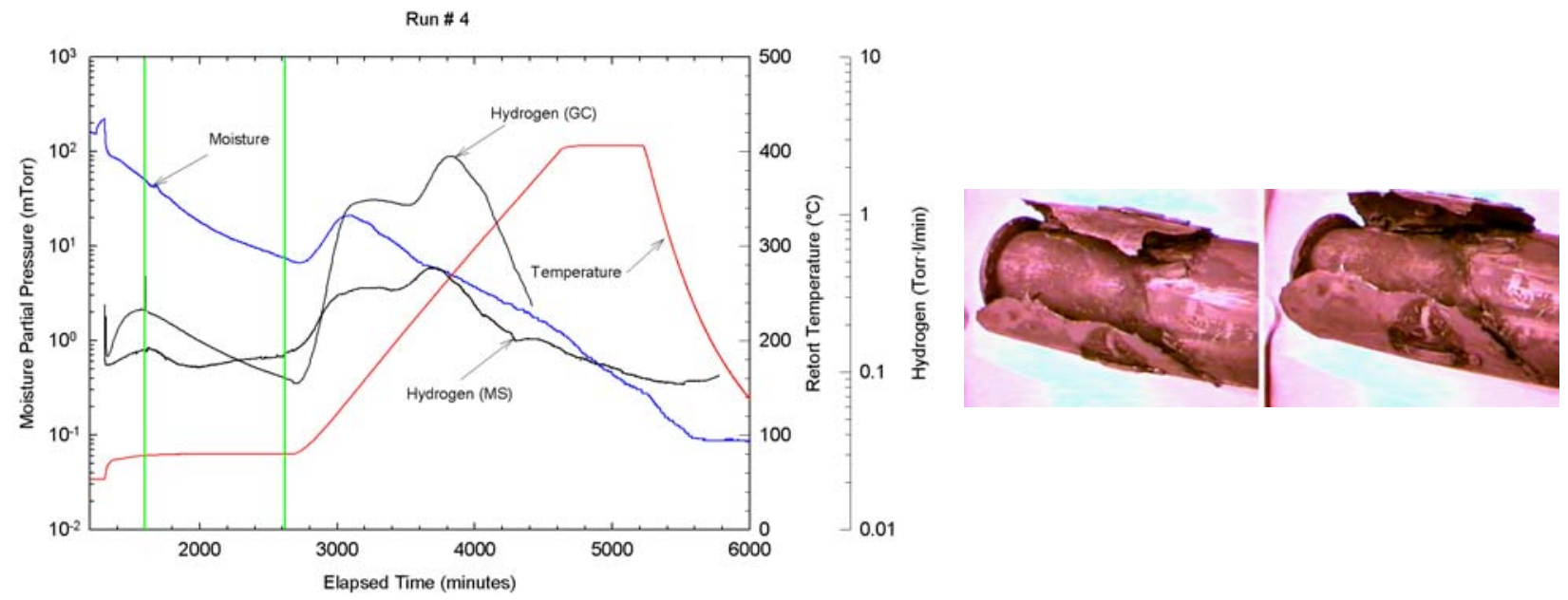

Figure A.2. Hydrogen Generation Rate (left) for the Corroded SNF Element 5744U (right) at Different Temperatures. The two green lines border the analyzed region. 

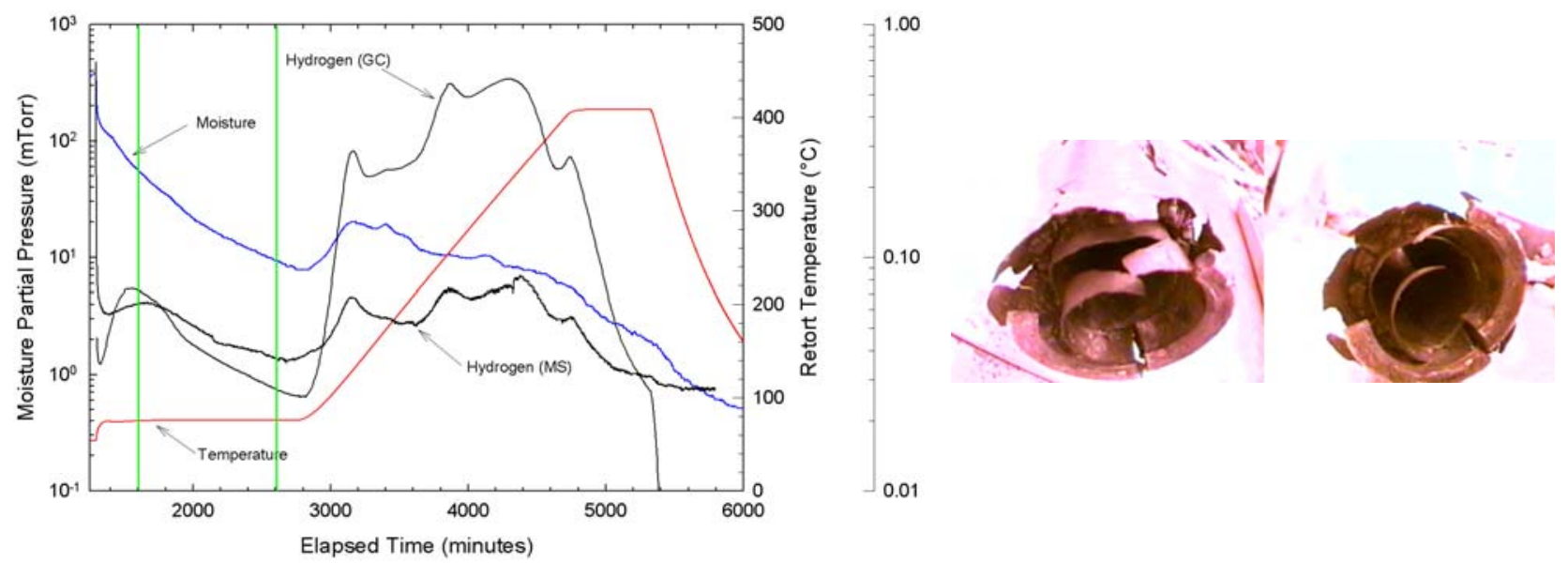

Figure A.3. Hydrogen Generation Rate (left) for the Corroded SNF Element 6603M (right) at Different Temperatures. The two green lines border the analyzed region.
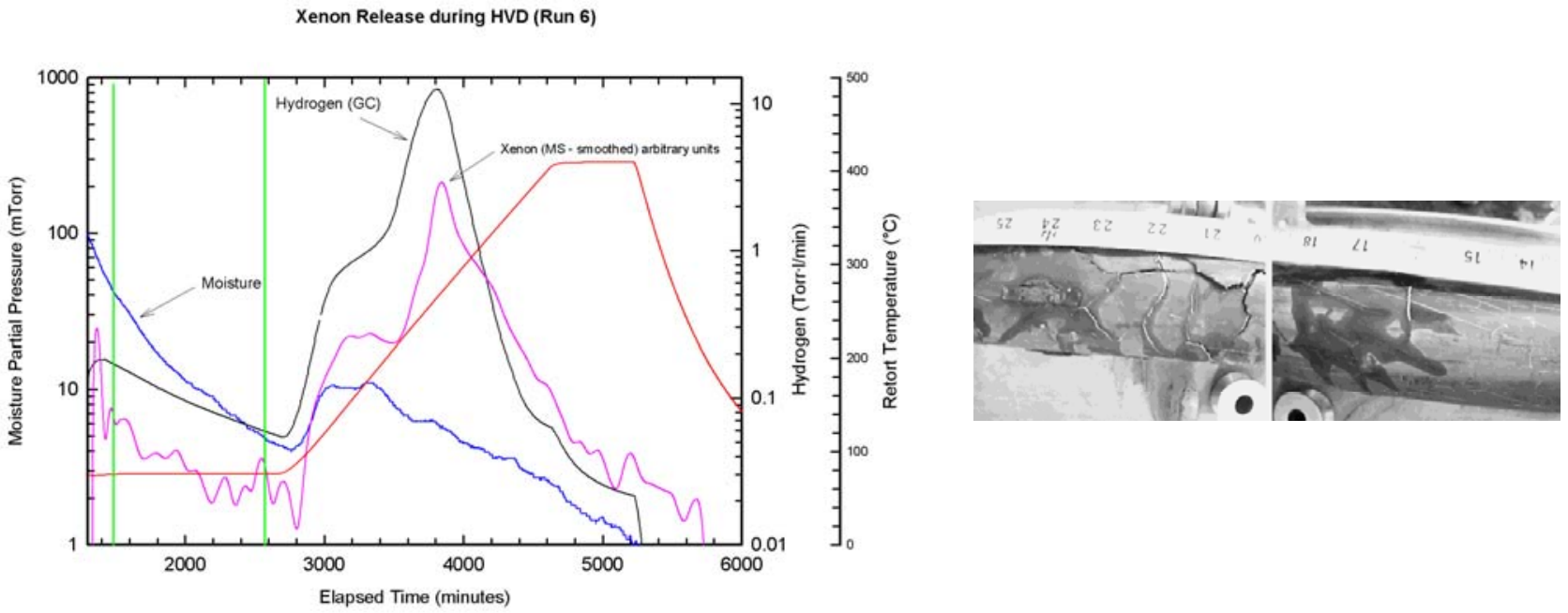

Figure A.4. Hydrogen Generation Rate (left) for the Cracked SNF Element 1164M (right) at Different Temperatures. The two green lines border the analyzed region. 

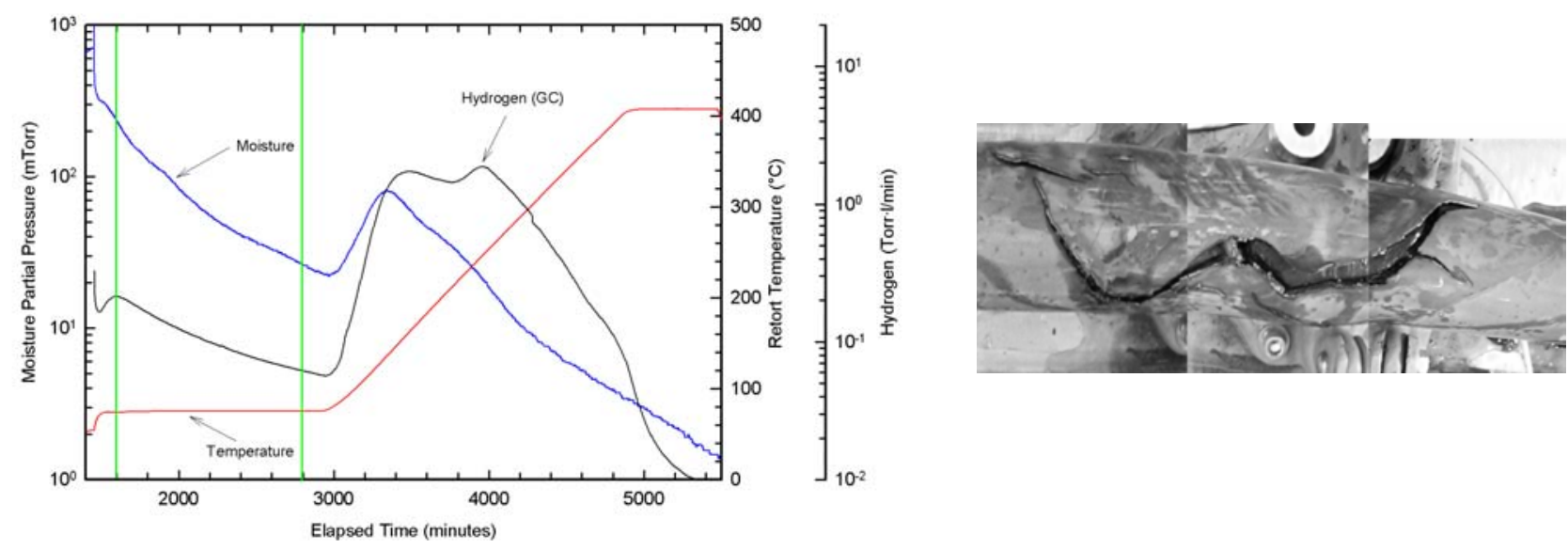

Figure A.5. Hydrogen Generation Rate (left) for the Cracked and Corroded SNF Element 2660M (right) at Different Temperatures. The two green lines border the analyzed region.

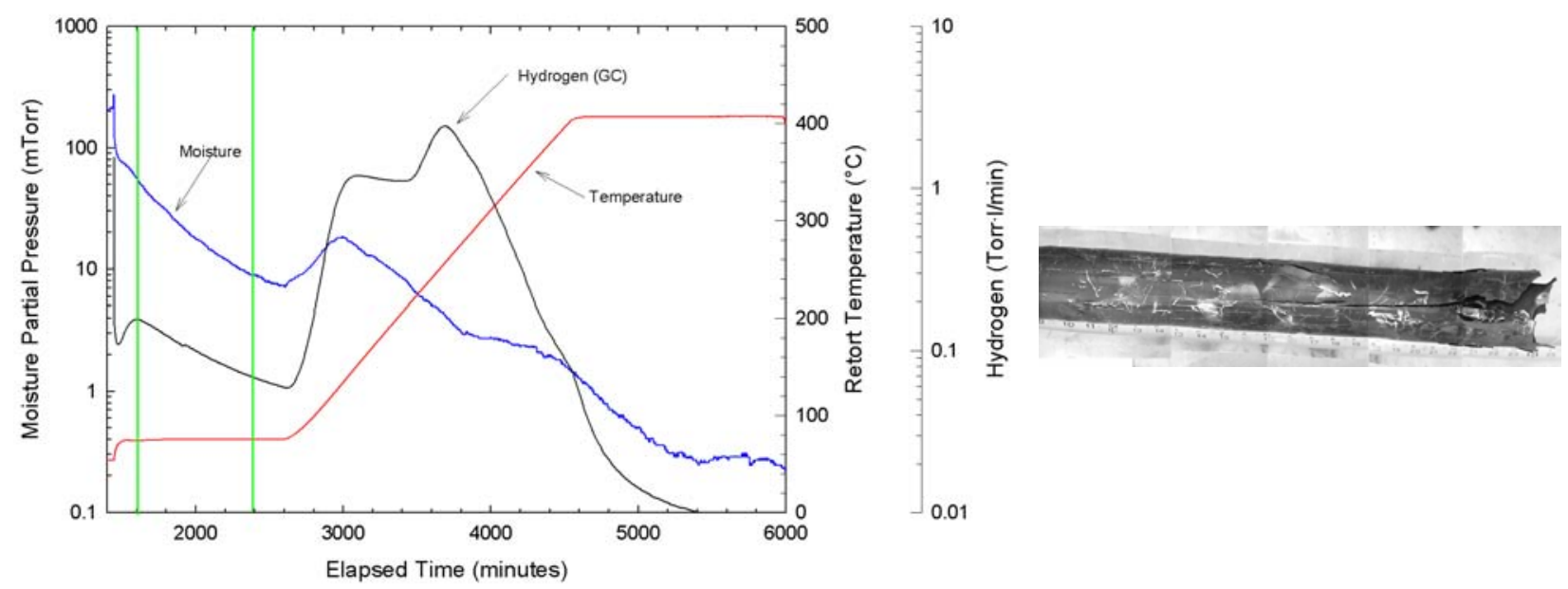

Figure A.6. Hydrogen Generation Rate (left) for the Cracked and Corroded SNF Element 6153U (right) at Different Temperatures. The two green lines border the analyzed region. 
Appendix B

SNF Surface Area in MCOs 


\section{Appendix B: SNF Surface Area in MCOs}

\section{Figures}

B1.1. Data Overview for MCO-36 Drying Process.

B.4

B1.2. Surface Area for Vacuum Cycle and Pretest $1 \& 2$ of MCO-36.

B.5

B1.3. Surface Area for Pretest 3 Segment of MCO-36.

B.6

B1.4. Surface Area for IRT Segment of MCO-36.

B.7

B2.1. Data Overview for MCO-35 Drying Process.

B.9

B2.2. Surface Area for Vacuum Cycle 1 Segment of MCO-35.

B. 10

B2.3. Surface Area for Vacuum Cycle 2 Segment of MCO-35.

B. 11

B2.4. Surface Area for Vacuum Cycle 3 Segment of MCO-35.

B. 12

B2.5. Surface Area for IRT Segment of MCO-35.

B. 13

B3.1. Data Overview for MCO-34 Drying Process.

B. 15

B3.2. Surface Area for First Vacuum Cycle of MCO-34.

B. 16

B3.3. Surface Area for IRT Segment of MCO-34.

B. 17

B4.1. Data Overview for MCO-32 Drying Process.

B. 19

B4.2. Surface Area for Vacuum Cycle 1 Segment of MCO-32.

B. 20

B4.3. Surface Area for Vacuum Cycle 2 Segment of MCO-32.

B. 21

B4.4. Surface Area for Third Vacuum Cycle Segment of MCO-32.

B.22

B4.5. Surface Area for IRT Segment of MCO-32.

B. 23

B4.6. Data Overview for MCO-32 Re-Drying Process.

B. 24

B4.7. Surface Area for IRT Segment of MCO-32 Re-Dry.

B. 25

B5.1. Data Overview for MCO-69 Drying Process.

B. 27 
B5.2. Surface Area for Vacuum Cycle 1 Segment of MCO-69.

B5.3. Surface Area for Vacuum Cycle 2 Segment of MCO-69.

B.29

B5.4. Surface Area for Vacuum Cycle 3 Segment of MCO-69.

B.30

B6.1. Data Overview for MCO-89 Drying Process.

B.32

B6.2. Surface Area for Vacuum Cycle 1 Segment of MCO-89.

B.33

B6.3. Surface Area for Vacuum Cycle 2 Segment of MCO-89.

B.34

B6.4. Surface Area for Vacuum Cycle 3 Segment of MCO-89.

B.35

B6.5. Surface Area for IRT Segment of MCO-89.

B.36

B7.1. Data Overview for MCO-82 Drying Process.

B.38

B7.2. Surface Area for Vacuum Cycle 1 Segment of MCO-82.

B.39

B7.3. Data Overview for MCO-88 Drying Process.

B. 40

B7.4. Surface Area for Vacuum Cycle 1 Segment of MCO-88.

B.41

B7.5. Surface Area for Vacuum Cycle 2 Segment of MCO-88.

B. 42

\section{Tables}

B.1 MCO-36 (\#1) Drying Process Analysis.......................................................... B.3

B.2 MCO-35 (\#2) Drying Process Analysis......................................................... B. B.

B.3 MCO-34 (\#3) Drying Process Analysis................................................................ B.14

B.4 MCO-32 (\#5) Drying Process Analysis................................................................... B.. B.

B.5 MCO-69 (\#6) Drying Process Analysis........................................................... B.26

B.6 MCO-89 (\#8) Drying Process Analysis........................................................... B...

B.7 MCOs-82 \& 88 Drying Process Analyses ................................................... B. 37 


\section{B.1. MCO-36 (\#1) Drying Process Analysis}

\begin{tabular}{|c|c|c|c|c|c|c|c|c|}
\hline \multirow{2}{*}{1} & MCO 36 (Seq.\#1) & \multicolumn{7}{|c|}{$\begin{array}{c}\text { Vacuum Cycle Start Date \& Time (SDT) } \\
12 / 09 / 00,14: 00 \\
\end{array}$} \\
\hline & \multicolumn{2}{|c|}{ Process $\Rightarrow$} & \multicolumn{3}{|c|}{ VacCy-1, and Pretest $1 \& 2$} & Pretest-3 & $\begin{array}{c}\text { Rebnd } \\
\text { Test }\end{array}$ & \multirow{4}{*}{$\begin{array}{l}\text { Over All } \\
\text { Averages }\end{array}$} \\
\hline 3 & \multicolumn{2}{|c|}{$\begin{array}{c}t=0 \text { \& End Pts. for Analysis } \\
(\text { min from SDT) }\end{array}$} & \multicolumn{3}{|c|}{$167 \& 473$} & $\begin{array}{c}776 \& \\
827\end{array}$ & $\begin{array}{c}1829 \& \\
2228\end{array}$ & \\
\hline 4 & \multicolumn{2}{|l|}{ Figure No. $\Rightarrow$} & \multicolumn{3}{|c|}{ B1.2 } & B1.3 & B1.4 & \\
\hline & Data Type $\downarrow$ & U一nits $\downarrow$ & VacCy-1 & Pretest-1 & Pretest-2 & & & \\
\hline 5 & Avg. Temp. & $\mathrm{K}$ & $\begin{array}{c}317.62 \pm \\
0.10\end{array}$ & $\begin{array}{l}317.62 \\
\pm 0.10\end{array}$ & $\begin{array}{l}317.62 \\
\pm 0.10\end{array}$ & $\begin{array}{l}317.61 \\
\pm 0.10\end{array}$ & $\begin{array}{l}317.61 \\
\pm 0.10\end{array}$ & $\begin{array}{l}317.62 \\
\pm 0.05\end{array}$ \\
\hline 6 & Avg. Total Press. & $\mathrm{Pa}$ & $\begin{array}{r}67.86 \\
\pm 3.38 \\
\end{array}$ & $\begin{array}{r}62.07 \\
\pm 3.53 \\
\end{array}$ & $\begin{array}{l}61.84 \\
\pm 0.10\end{array}$ & $\begin{array}{l}55.42 \\
\pm 3.13\end{array}$ & $\begin{array}{l}48.64 \\
\pm 1.47\end{array}$ & $\begin{array}{r}61.78 \\
\pm 0.10\end{array}$ \\
\hline 7 & Avg. Total Moles & mMoles & $\begin{array}{r}18.24 \\
\pm 0.91 \\
\end{array}$ & $\begin{array}{r}16.69 \\
\pm 0.95 \\
\end{array}$ & $\begin{array}{r}16.63 \\
\pm 0.03 \\
\end{array}$ & $\begin{array}{r}14.90 \\
\pm 0.84 \\
\end{array}$ & $\begin{array}{l}13.07 \\
\pm 0.40 \\
\end{array}$ & $\begin{array}{r}16.61 \\
\pm 0.03 \\
\end{array}$ \\
\hline 8 & $\begin{array}{l}\text { Vacuum Pump } \\
\text { OutFlow Rate }\end{array}$ & $\begin{array}{l}\text { mMole } \\
\text { per min }\end{array}$ & $\begin{array}{r}18.08 \\
\pm 1.28\end{array}$ & $\begin{array}{c}15.90 \\
\pm 14.57\end{array}$ & $\begin{array}{l}15.81 \\
\pm 0.04\end{array}$ & $\begin{array}{r}13.39 \\
\pm 1.18\end{array}$ & $\begin{array}{l}10.84 \\
\pm 0.56\end{array}$ & $\begin{array}{r}15.79 \\
\pm 0.04\end{array}$ \\
\hline 9 & $\mathrm{~N}_{2} \quad$ Avg. \%vol. & $\%$ & $\begin{array}{c}6.92 \\
\pm 0.91 \\
\end{array}$ & $\begin{array}{r}9.16 \\
\pm 0.48\end{array}$ & $\begin{array}{c}10.11 \\
\pm 0.43\end{array}$ & $\begin{array}{r}13.97 \\
\pm 1.48\end{array}$ & $\begin{array}{l}51.72 \\
\pm 7.99\end{array}$ & $\begin{array}{c}9.63 \\
\pm 0.29\end{array}$ \\
\hline 10 & He Avg. \%vol. & $\%$ & $\begin{array}{r}9.27 \\
\pm 0.31 \\
\end{array}$ & $\begin{array}{c}9.84 \\
\pm 0.26\end{array}$ & $\begin{array}{r}10.18 \\
\pm 0.17\end{array}$ & $\begin{array}{r}11.80 \\
\pm 1.00 \\
\end{array}$ & $\begin{array}{c}8.94 \\
\pm 1.20 \\
\end{array}$ & $\begin{array}{c}9.97 \\
\pm 0.13 \\
\end{array}$ \\
\hline 11 & $\mathrm{H}_{2} \mathrm{O}$ Avg. \%vol. & $\%$ & $\begin{array}{l}81.37 \\
\pm 1.40\end{array}$ & $\begin{array}{l}77.93 \\
\pm 0.62\end{array}$ & $\begin{array}{l}76.36 \\
\pm 0.57\end{array}$ & $\begin{array}{l}69.82 \\
\pm 1.10\end{array}$ & $\begin{array}{l}24.58 \\
\pm 9.21\end{array}$ & $\begin{array}{r}76.46 \\
\pm 0.38\end{array}$ \\
\hline 12 & $\mathrm{H}_{2} \quad$ Avg. \%vol. & $\%$ & $\begin{array}{c}0.18 \\
\pm 0.03 \\
\end{array}$ & $\begin{array}{c}0.10 \\
\pm 0.01 \\
\end{array}$ & $\begin{array}{c}0.09 \\
\pm 0.00 \\
\end{array}$ & $\begin{array}{c}0.10 \\
\pm 0.01 \\
\end{array}$ & $\begin{array}{c}0.22 \\
\pm 0.07\end{array}$ & $\begin{array}{c}0.10 \\
\pm 0.00\end{array}$ \\
\hline 13 & $\begin{array}{l}\text { Avg. } \\
\mathrm{H}_{2} \text {-LSQ Slope }\end{array}$ & $\mu \mathrm{g} / \mathrm{min}$ & $\begin{array}{c}0.23 \\
\pm 0.01 \\
\end{array}$ & $\begin{array}{c}0.15 \\
\pm 0.01 \\
\end{array}$ & $\begin{array}{c}0.22 \\
\pm 0.01 \\
\end{array}$ & $\begin{array}{c}0.21 \\
\pm 0.02 \\
\end{array}$ & $\begin{array}{c}0.14 \\
\pm 0.01 \\
\end{array}$ & $\begin{array}{c}0.16 \\
\pm 0.00 \\
\end{array}$ \\
\hline 14 & $\begin{array}{l}\text { Avg. } \mathrm{H}_{2} \mathrm{O} \\
\text { Removal Rate }\end{array}$ & $\mathrm{g} / \mathrm{h}$ & 1.23 & 0.97 & 0.96 & 0.58 & 0.11 & 0.77 \\
\hline 15 & \begin{tabular}{|l} 
Avg. Air \\
Inleak Rate
\end{tabular} & $\mathrm{mL} / \mathrm{h}$ & 0.95 & 1.26 & 1.39 & 1.93 & 7.13 & 1.27 \\
\hline 16 & $\begin{array}{l}\text { Avg. } \\
\text { Reactive Area }\end{array}$ & $\mathrm{m}^{2}$ & $\begin{array}{c}0.15 \\
\pm 0.01\end{array}$ & $\begin{array}{c}0.10 \\
\pm 0.01\end{array}$ & $\begin{array}{c}0.15 \\
\pm 0.01\end{array}$ & $\begin{array}{c}0.16 \\
\pm 0.02\end{array}$ & $\begin{array}{c}0.19 \\
\pm 0.04\end{array}$ & $\begin{array}{c}0.13 \\
\pm 0.01\end{array}$ \\
\hline
\end{tabular}




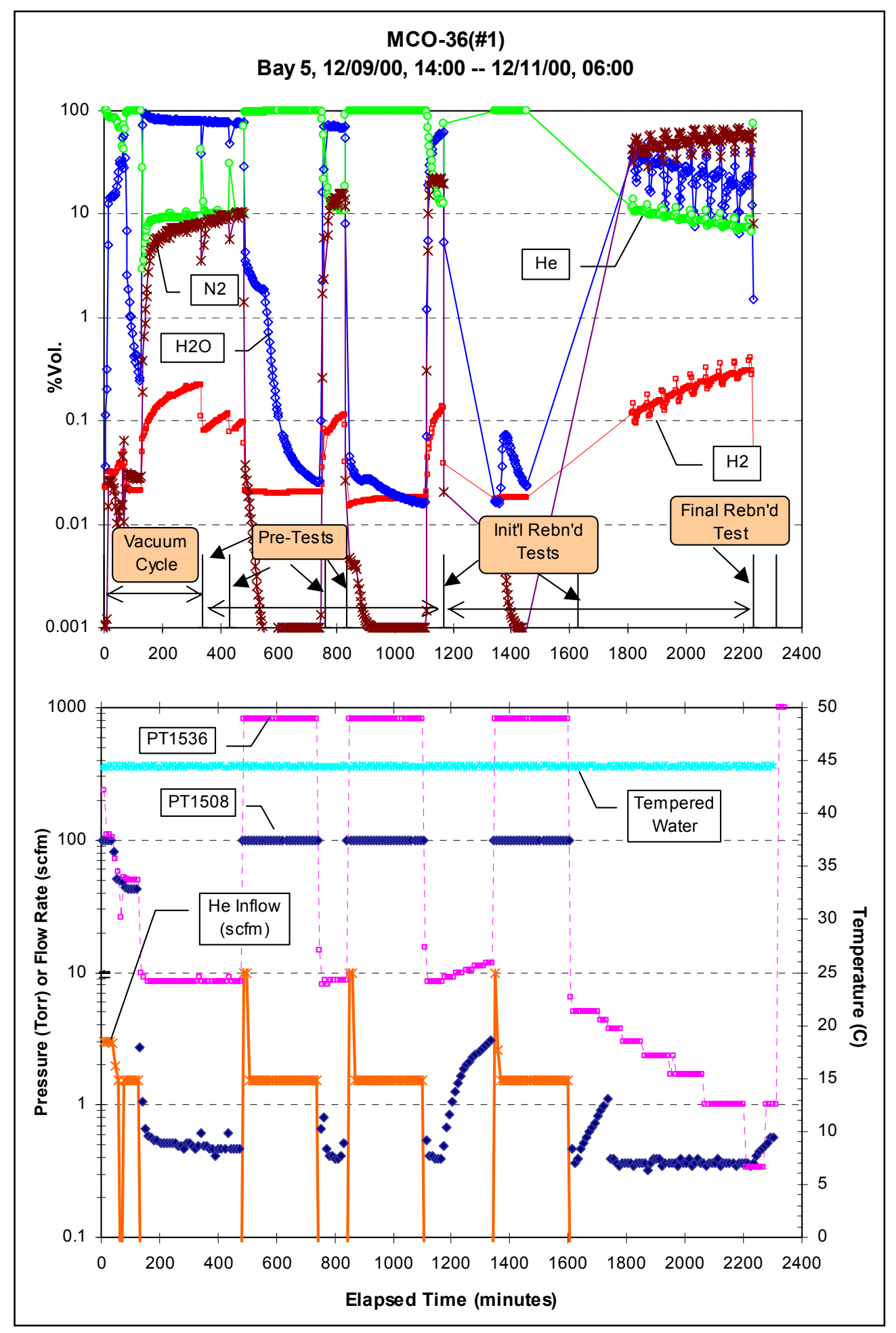

Figure B1.1. Data Overview for MCO-36 Drying Process 


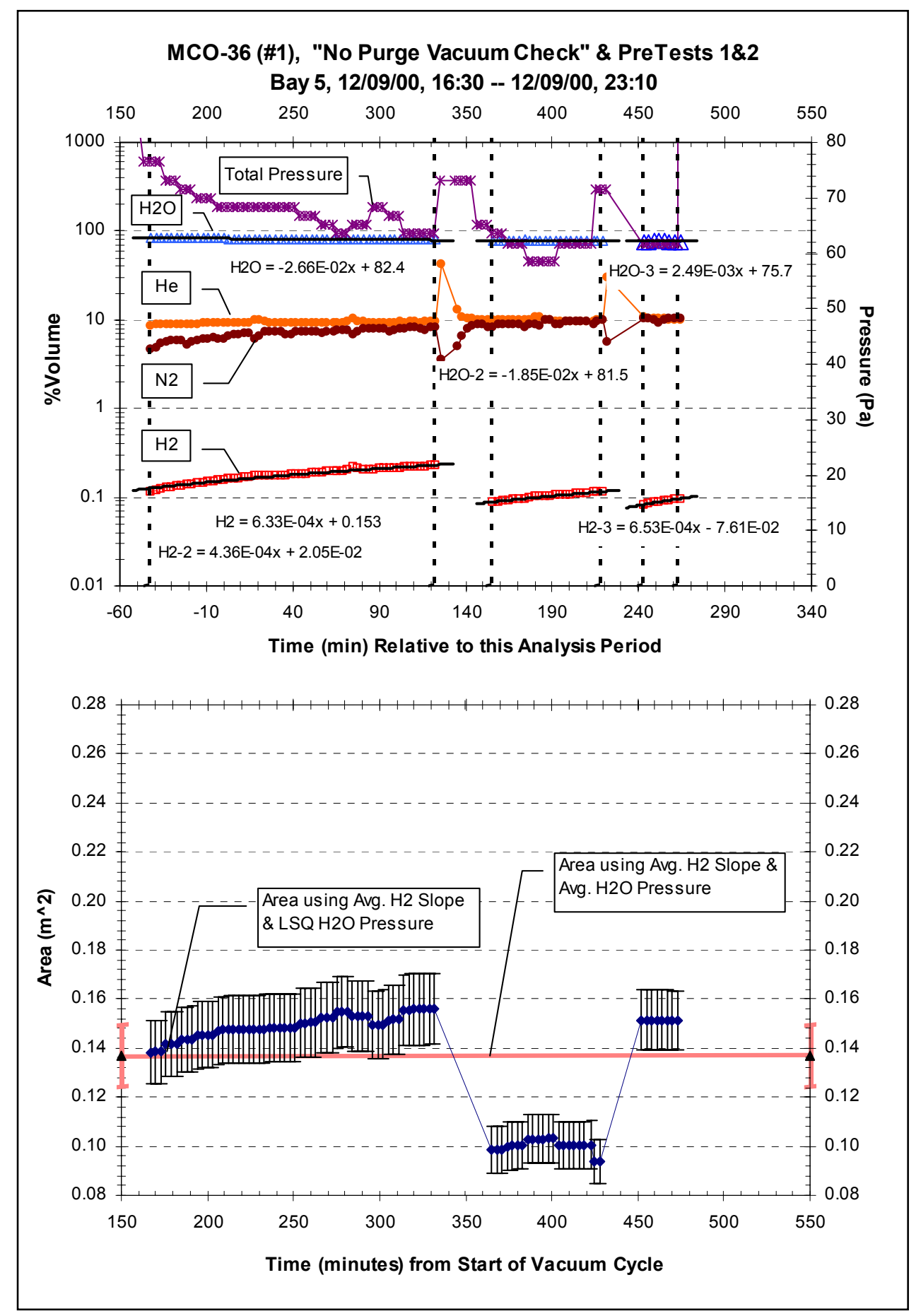

Figure B1.2. Surface Area for Vacuum Cycle \& Pretests 1 - 2 of MCO-36 


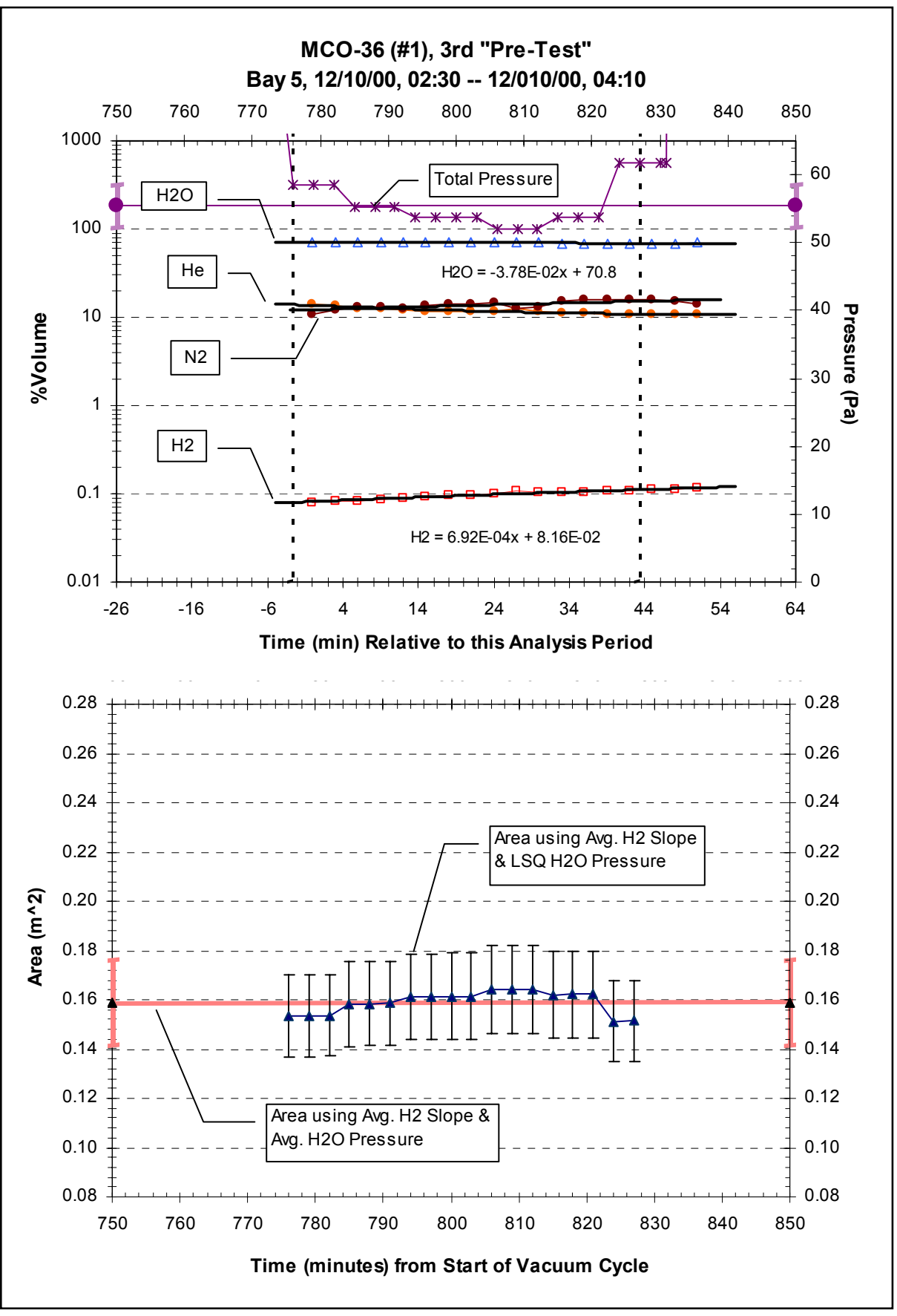

Figure B1.3. Surface Area for Pretest 3 Segment of MCO-36 


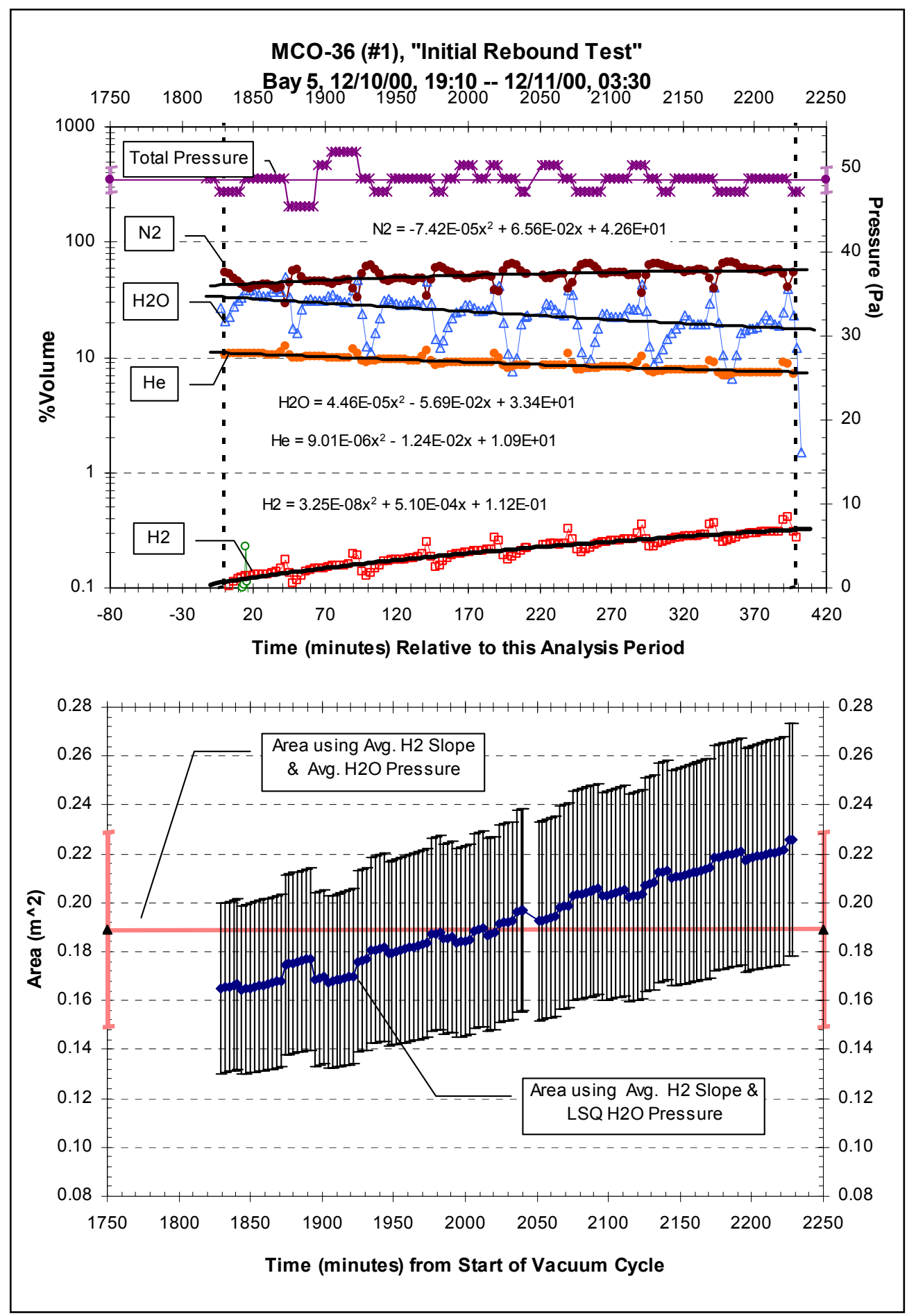

Figure B1.4. Surface Area for IRT Segment of MCO-36 


\section{B.2. MCO-35 (32) DRYING PROCESS ANALYSIS}

\begin{tabular}{|c|c|c|c|c|c|c|c|}
\hline 1 & $\begin{array}{l}\text { MCO 35 } \\
\text { (Seq.\#2) } \\
\end{array}$ & & Vacuu & $\begin{array}{r}\text { Cycle Sta } \\
02 / 03 \\
\end{array}$ & $\begin{array}{l}\text { Date \& } \\
1,09: 15\end{array}$ & me (SDT) & \\
\hline 2 & \multicolumn{2}{|c|}{ Process $\Rightarrow$} & $\begin{array}{c}\text { VacCy- } \\
1 \\
\end{array}$ & $\begin{array}{c}\text { VacCy- } \\
2\end{array}$ & $\begin{array}{c}\text { VacCy- } \\
3\end{array}$ & $\begin{array}{l}\text { Rebnd } \\
\text { Test }\end{array}$ & \multirow{4}{*}{$\begin{array}{l}\text { Over All } \\
\text { Averages }\end{array}$} \\
\hline 3 & \multicolumn{2}{|c|}{$\begin{array}{c}t=0 \text { \& End Pts. for Analysis } \\
(\text { min from SDT) }\end{array}$} & $\begin{array}{c}215 \& \\
458 \\
\end{array}$ & $\begin{array}{c}800 \& \\
945 \\
\end{array}$ & $\begin{array}{c}1295 \& \\
1448 \\
\end{array}$ & $\begin{array}{l}2252 \& \\
2699 \\
\end{array}$ & \\
\hline 4 & \multicolumn{2}{|l|}{ Figure No. $\Rightarrow$} & B2.2 & B2.3 & B2.4 & B2.5 & \\
\hline & Data Type $\Downarrow$ & $\overline{~ U n i t s \Downarrow}$ & & & & & \\
\hline 5 & Avg. Temp. & $\mathrm{K}$ & $\begin{array}{r}315.71 \\
\pm 0.09 \\
\end{array}$ & $\begin{array}{l}315.64 \\
\pm 0.03 \\
\end{array}$ & $\begin{array}{l}315.74 \\
\pm 0.02 \\
\end{array}$ & $\begin{array}{l}315.67 \\
\pm 0.07 \\
\end{array}$ & $\begin{array}{r}315.71 \\
\pm 0.02 \\
\end{array}$ \\
\hline 6 & Avg. Total Press. & $\mathrm{Pa}$ & $\begin{array}{r}139.32 \\
\pm 43.15\end{array}$ & $\begin{array}{r}78.42 \\
\pm 2.63 \\
\end{array}$ & $\begin{array}{r}70.23 \\
\pm 1.86 \\
\end{array}$ & $\begin{array}{r}59.16 \\
\pm 2.11\end{array}$ & $\begin{array}{r}68.30 \\
\pm 1.23 \\
\end{array}$ \\
\hline 7 & Avg. Total Moles & mMoles & $\begin{array}{r}37.68 \\
\pm 11.67 \\
\end{array}$ & $\begin{array}{r}21.21 \\
\pm 0.71 \\
\end{array}$ & $\begin{array}{r}18.99 \\
\pm 0.50 \\
\end{array}$ & $\begin{array}{r}16.00 \\
\pm 0.57 \\
\end{array}$ & $\begin{array}{r}18.47 \\
\pm 0.33 \\
\end{array}$ \\
\hline 8 & $\begin{array}{l}\text { Vacuum Pump } \\
\text { OutFlow Rate }\end{array}$ & $\begin{array}{l}\text { mMoles } \\
\text { per min }\end{array}$ & $\begin{array}{l}45.29 \\
\pm 16.36\end{array}$ & $\begin{array}{r}22.20 \\
\pm 1.00\end{array}$ & $\begin{array}{r}19.09 \\
\pm 0.71\end{array}$ & $\begin{array}{r}14.89 \\
\pm 0.80\end{array}$ & $\begin{array}{r}18.36 \\
\pm 0.47\end{array}$ \\
\hline 9 & $\mathrm{~N}_{2} \quad$ Avg. \%vol. & $\%$ & $\begin{array}{r}2.34 \\
\pm 1.41 \\
\end{array}$ & $\begin{array}{c}8.24 \\
\pm 0.68 \\
\end{array}$ & $\begin{array}{r}14.66 \\
\pm 2.27 \\
\end{array}$ & $\begin{array}{r}50.90 \\
\pm 8.21 \\
\end{array}$ & $\begin{array}{c}7.86 \\
\pm 0.59 \\
\end{array}$ \\
\hline 10 & He Avg. \%vol. & $\%$ & $\begin{array}{c}0.87 \\
\pm 0.35 \\
\end{array}$ & $\begin{array}{c}9.23 \\
\pm 0.46\end{array}$ & $\begin{array}{c}9.21 \\
\pm 0.62\end{array}$ & $\begin{array}{c}10.14 \\
\pm 4.44\end{array}$ & $\begin{array}{c}4.80 \\
\pm 0.25\end{array}$ \\
\hline 11 & $\mathrm{H}_{2} \mathrm{O}$ Avg. \%vol. & $\%$ & $\begin{array}{l}90.38 \\
\pm 3.38\end{array}$ & $\begin{array}{l}78.33 \\
\pm 0.73\end{array}$ & $\begin{array}{l}69.58 \\
\pm 2.74\end{array}$ & $\begin{array}{c}17.64 \\
\pm 8.42\end{array}$ & $\begin{array}{l}77.87 \\
\pm 0.69\end{array}$ \\
\hline 12 & $\mathrm{H}_{2} \quad$ Avg. \%vol. & $\%$ & $\begin{array}{r}0.99 \\
\pm 0.49 \\
\end{array}$ & $\begin{array}{c}1.76 \\
\pm 0.30 \\
\end{array}$ & $\begin{array}{c}2.38 \\
\pm 0.50 \\
\end{array}$ & $\begin{array}{r}8.14 \\
\pm 2.52 \\
\end{array}$ & $\begin{array}{r}1.78 \\
\pm 0.23 \\
\end{array}$ \\
\hline 13 & $\begin{array}{l}\text { Avg. } \\
\mathrm{H}_{2} \text {-LSQ Slope }\end{array}$ & $\mu \mathrm{g} / \mathrm{min}$ & $\begin{array}{l}4.88 \\
\pm 0.11 \\
\end{array}$ & $\begin{array}{c}2.99 \\
\pm 0.12\end{array}$ & $\begin{array}{c}4.14 \\
\pm 0.17\end{array}$ & $\begin{array}{c}4.41 \\
\pm 0.07\end{array}$ & $\begin{array}{c}4.02 \\
\pm 0.07\end{array}$ \\
\hline 14 & $\begin{array}{l}\text { Avg. } \mathrm{H}_{2} \mathrm{O} \\
\text { Removal Rate }\end{array}$ & $\mathrm{g} / \mathrm{h}$ & $\begin{array}{c}0.49 \\
\pm 0.25\end{array}$ & $\begin{array}{c}0.11 \\
\pm 0.07\end{array}$ & $\begin{array}{c}0.07 \\
\pm 0.05\end{array}$ & $\begin{array}{c}0.01 \\
\pm 0.00\end{array}$ & $\begin{array}{c}0.17 \\
\pm 0.38\end{array}$ \\
\hline 15 & $\begin{array}{l}\text { Avg. Air } \\
\text { Inleak Rate }\end{array}$ & $\mathrm{mL} / \mathrm{h}$ & $\begin{array}{r}0.10 \\
\pm 0.02 \\
\end{array}$ & $\begin{array}{c}0.35 \\
\pm 0.07 \\
\end{array}$ & $\begin{array}{c}0.63 \\
\pm 0.13 \\
\end{array}$ & $\begin{array}{c}2.19 \\
\pm 0.44 \\
\end{array}$ & $\begin{array}{c}0.82 \\
\pm 0.66 \\
\end{array}$ \\
\hline 16 & $\begin{array}{l}\text { Avg. } \\
\text { Reactive Area }\end{array}$ & $\mathrm{m}^{2}$ & $\begin{array}{c}2.34 \\
\pm 0.85\end{array}$ & $\begin{array}{c}2.06 \\
\pm 0.17\end{array}$ & $\begin{array}{c}3.19 \\
\pm 0.27\end{array}$ & $\begin{array}{c}7.38 \\
\pm 1.94\end{array}$ & $\begin{array}{c}2.41 \\
\pm 0.14\end{array}$ \\
\hline
\end{tabular}




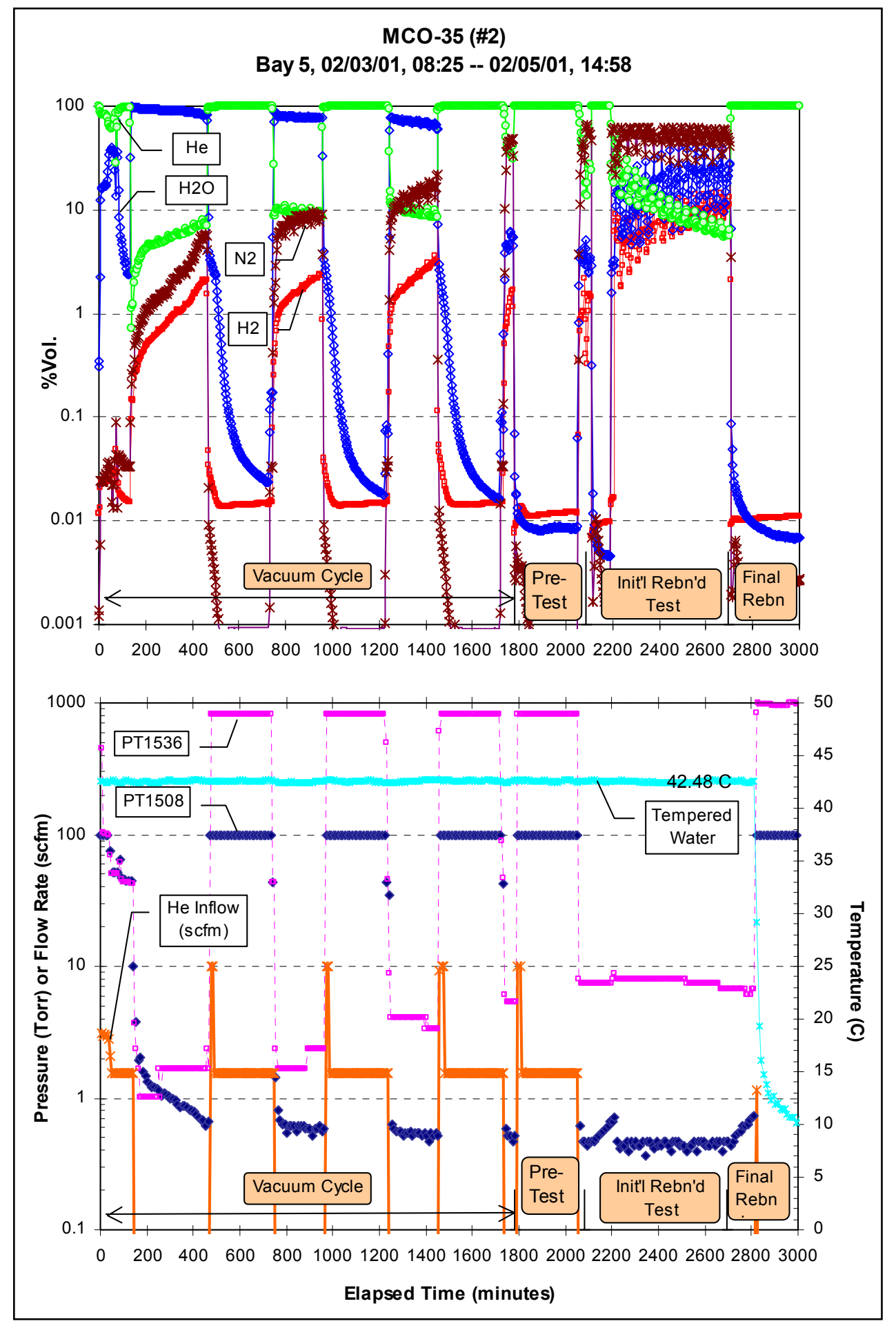

Figure B2.1. Data Overview for MCO-35 Drying Process 


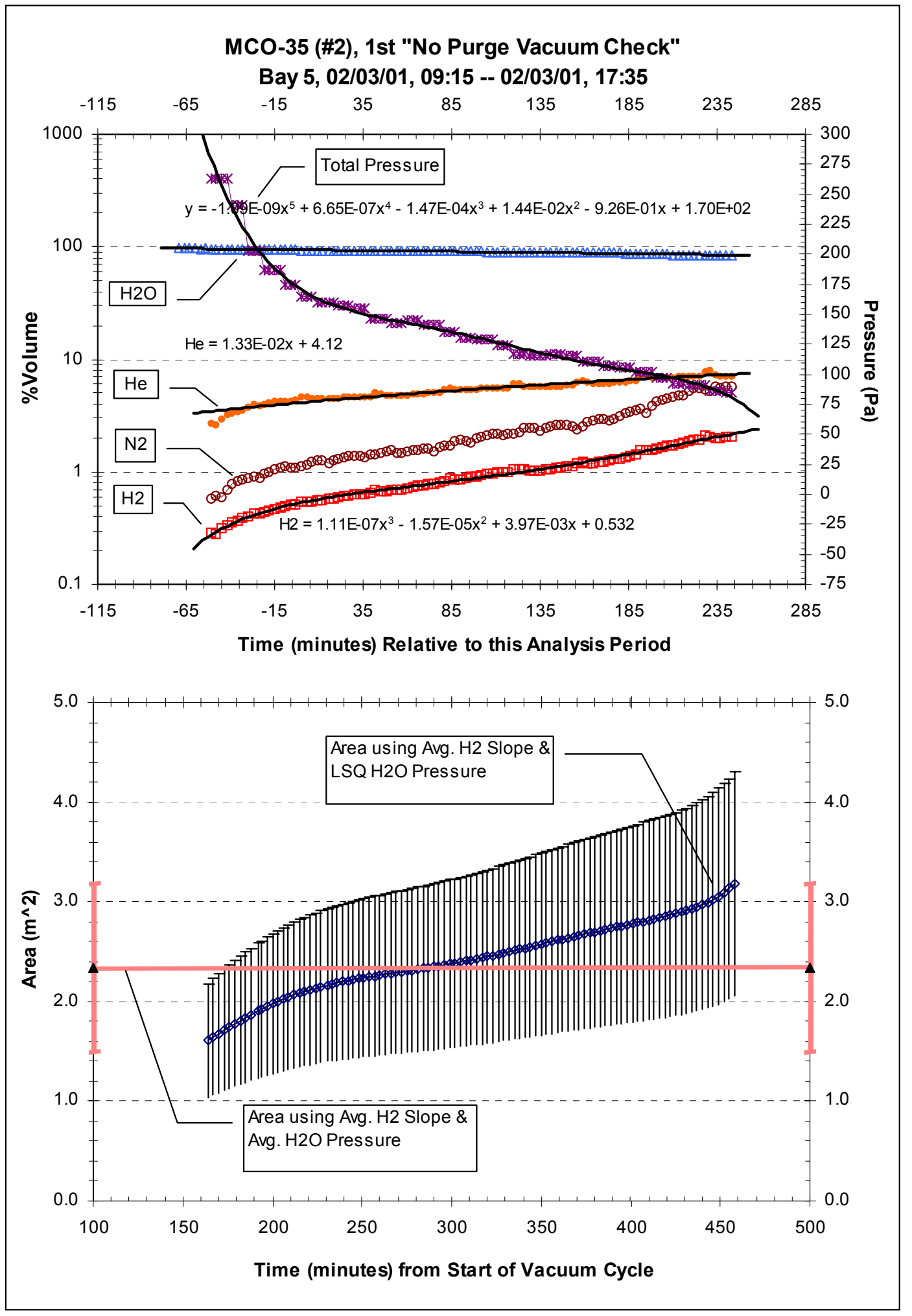

Figure B2.2. Surface Area for Vacuum Cycle 1 Segment of MCO-35 


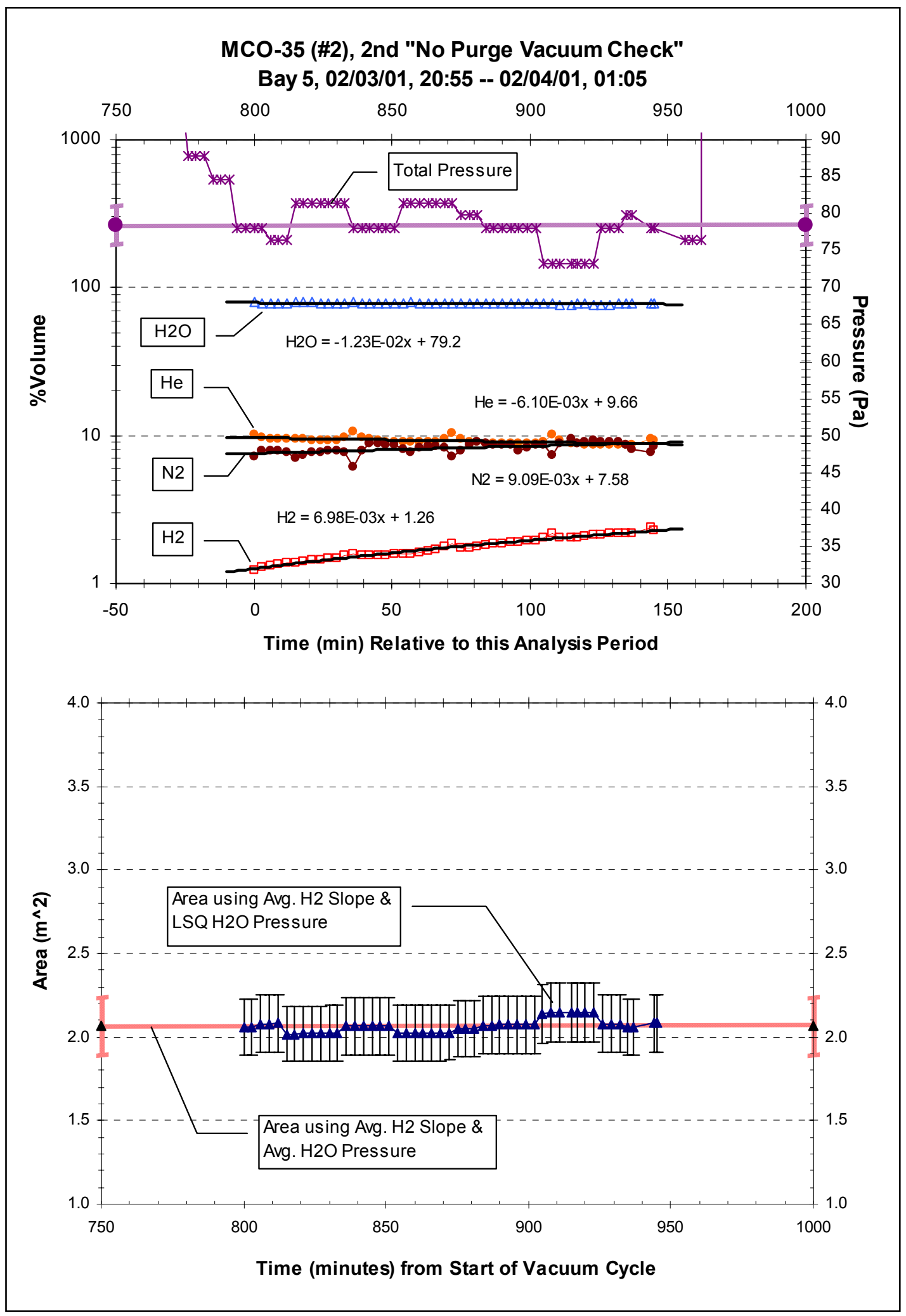

Figure B2.3. Surface Area for Vacuum Cycle 2 Segment of MCO-35 


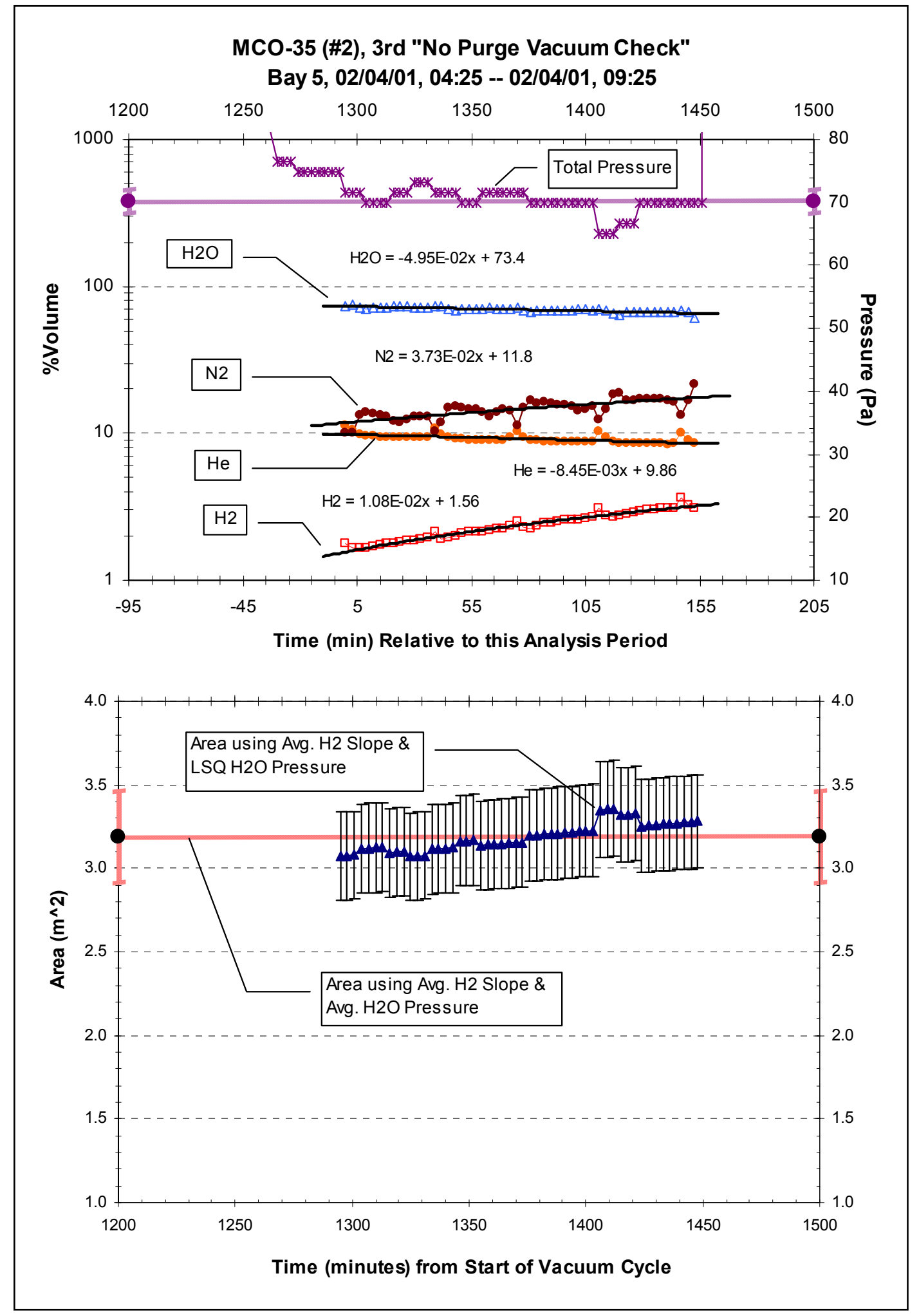

Figure B2.4. Surface Area for Vacuum Cycle 3 Segment of MCO-35 


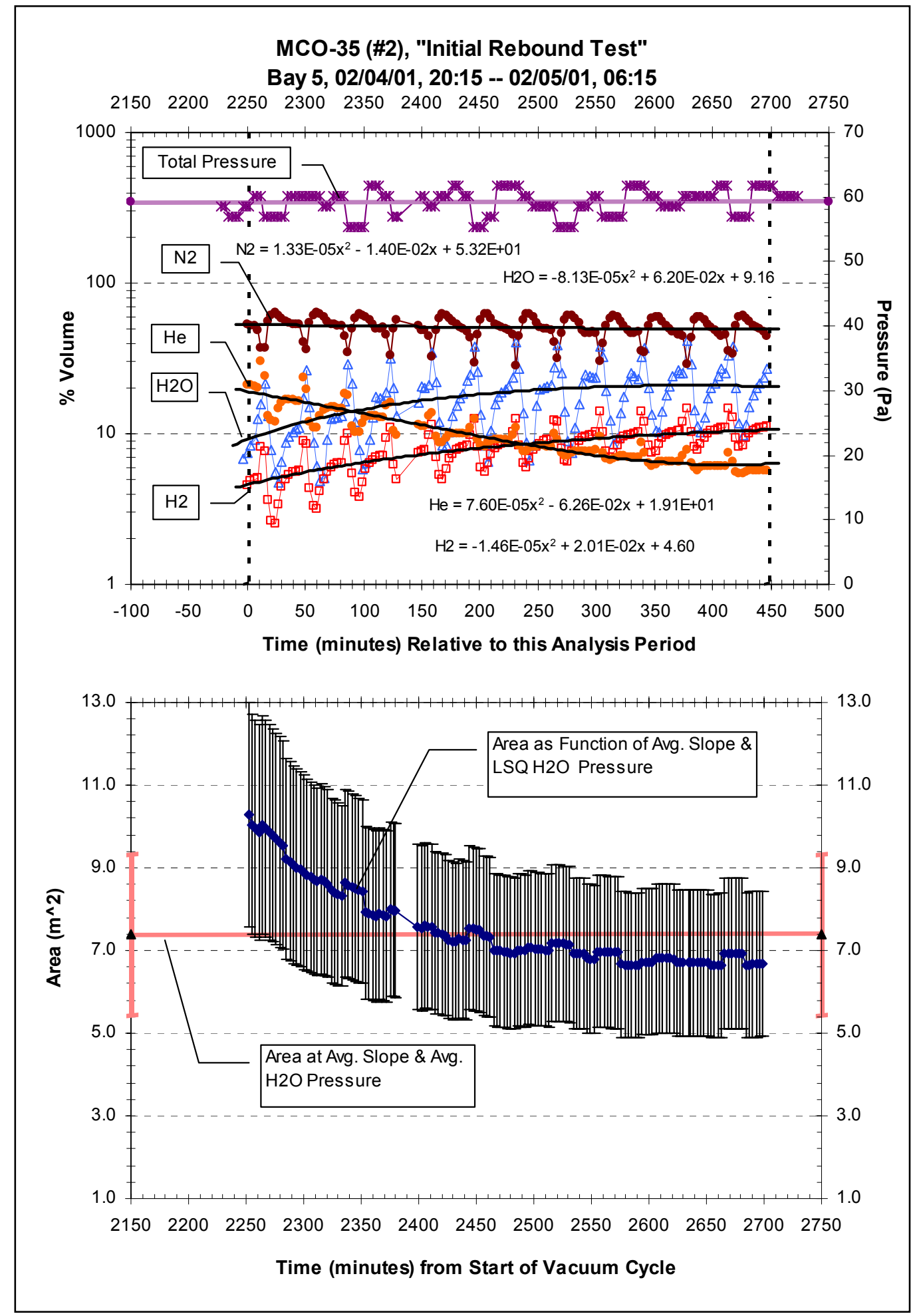

Figure B2.5. Surface Area for IRT Segment of MCO-35 


\section{B.3. MCO-34 (\#3) Drying Process Analysis}

\begin{tabular}{|c|c|c|c|c|c|c|c|}
\hline 1 & $\begin{array}{l}\text { MCO 34 } \\
\text { (Seq.\#3) }\end{array}$ & & Vacuur & $\begin{array}{r}\text { Cycle Sta } \\
02 / 16\end{array}$ & $\begin{array}{l}\text { Date \& } \\
1,02: 40\end{array}$ & me (SDT) & \\
\hline 2 & \multicolumn{2}{|c|}{ Process $\Rightarrow$} & $\begin{array}{c}\text { VacCy- } \\
1\end{array}$ & $\begin{array}{l}\text { VacCy- } \\
2\end{array}$ & $\begin{array}{c}\text { VacCy- } \\
3\end{array}$ & $\begin{array}{l}\text { Rebnd } \\
\text { Test }\end{array}$ & \multirow{4}{*}{$\begin{array}{l}\text { Over All } \\
\text { Averages }\end{array}$} \\
\hline 3 & $\begin{array}{r}t=0 \text { \& End Pts. fo } \\
(\text { min from } \mathrm{S}\end{array}$ & $\begin{array}{l}\text { Analysis } \\
\text { T) }\end{array}$ & $\begin{array}{c}212 \& \\
458\end{array}$ & $\begin{array}{r}\text { Cycles } \\
\text { Ava }\end{array}$ & $\begin{array}{l}\text { ata not } \\
\text { able }\end{array}$ & $\begin{array}{l}1361 \& \\
1715\end{array}$ & \\
\hline 4 & \multicolumn{2}{|l|}{ Figure No. $\Rightarrow$} & B3.2 & & & B3.3 & \\
\hline & Data Type $\Downarrow$ & "Units $\downarrow$ & & & & & \\
\hline 5 & Avg. Temp. & $\mathrm{K}$ & $\begin{array}{l}317.61 \\
\pm 0.11\end{array}$ & & & $\begin{array}{l}317.63 \\
\pm 0.10\end{array}$ & $\begin{array}{l}317.62 \\
\pm 0.07\end{array}$ \\
\hline 6 & Avg. Total Press. & $\mathrm{Pa}$ & $\begin{array}{r}79.75 \\
\pm 9.68\end{array}$ & & & $\begin{array}{r}59.26 \\
\pm 2.01\end{array}$ & $\begin{array}{r}60.11 \\
\pm 1.97\end{array}$ \\
\hline 7 & Avg. Total Moles & mMoles & $\begin{array}{r}21.44 \\
\pm 2.60\end{array}$ & & & $\begin{array}{r}15.92 \\
\pm 0.54\end{array}$ & $\begin{array}{r}16.15 \\
\pm 0.53\end{array}$ \\
\hline 8 & $\begin{array}{l}\text { Vacuum Pump } \\
\text { OutFlow Rate }\end{array}$ & $\begin{array}{l}\text { mMoles } \\
\text { per min }\end{array}$ & $\begin{array}{r}22.56 \\
\pm 3.65\end{array}$ & & & $\begin{array}{c}14.84 \\
\pm 0.76\end{array}$ & $\begin{array}{l}15.16 \\
\pm 0.74\end{array}$ \\
\hline 9 & $\mathrm{~N}_{2} \quad$ Avg. \%vol. & $\%$ & $\begin{array}{c}5.61 \\
\pm 2.77\end{array}$ & & & $\begin{array}{r}40.23 \\
\pm 7.95\end{array}$ & $\begin{array}{c}9.37 \\
\pm 2.62\end{array}$ \\
\hline 10 & He Avg. \%vol. & $\%$ & $\begin{array}{c}15.11 \\
\pm 17.49\end{array}$ & & & $\begin{array}{c}9.01 \\
\pm 1.59\end{array}$ & $\begin{array}{c}9.06 \\
\pm 1.58\end{array}$ \\
\hline 11 & $\mathrm{H}_{2} \mathrm{O}$ Avg. \%vol. & $\%$ & $\begin{array}{r}75.20 \\
\pm 16.24\end{array}$ & & & $\begin{array}{c}30.27 \\
\pm 8.67\end{array}$ & $\begin{array}{r}40.24 \\
\pm 7.65\end{array}$ \\
\hline 12 & $\mathrm{H}_{2} \quad$ Avg. \%vol. & $\%$ & $\begin{array}{c}2.31 \\
\pm 1.19\end{array}$ & & & $\begin{array}{c}9.80 \\
\pm 2.24\end{array}$ & $\begin{array}{c}3.96 \\
\pm 1.05\end{array}$ \\
\hline 13 & $\begin{array}{l}\text { Avg. } \\
\mathrm{H}_{2} \text {-LSQ Slope }\end{array}$ & $\mu \mathrm{g} / \mathrm{min}$ & $\begin{array}{c}6.84 \\
\pm 0.09\end{array}$ & & & $\begin{array}{c}5.69 \\
\pm 0.37\end{array}$ & $\begin{array}{c}6.77 \\
\pm 0.09\end{array}$ \\
\hline 14 & $\begin{array}{l}\text { Avg. } \mathrm{H}_{2} \mathrm{O} \\
\text { Removal Rate }\end{array}$ & $\mathrm{g} / \mathrm{h}$ & $\begin{array}{c}0.32 \\
\pm 0.24\end{array}$ & & & $\begin{array}{c}0.05 \\
\pm 0.06\end{array}$ & $\begin{array}{c}0.19 \\
\pm 0.29\end{array}$ \\
\hline 15 & $\begin{array}{l}\text { Avg. Air } \\
\text { Inleak Rate }\end{array}$ & $\mathrm{mL} / \mathrm{h}$ & $\begin{array}{c}0.34 \\
\pm 0.05 \\
\end{array}$ & & & $\begin{array}{c}2.43 \\
\pm 0.35 \\
\end{array}$ & $\begin{array}{r}1.38 \\
\pm 0.40 \\
\end{array}$ \\
\hline 16 & $\begin{array}{l}\text { Avg. } \\
\text { Reactive Area }\end{array}$ & $\mathrm{m}^{2}$ & $\begin{array}{c}4.22 \\
\pm 0.81\end{array}$ & & & $\begin{array}{c}6.38 \\
\pm 1.11\end{array}$ & $\begin{array}{c}4.97 \\
\pm 0.66\end{array}$ \\
\hline
\end{tabular}




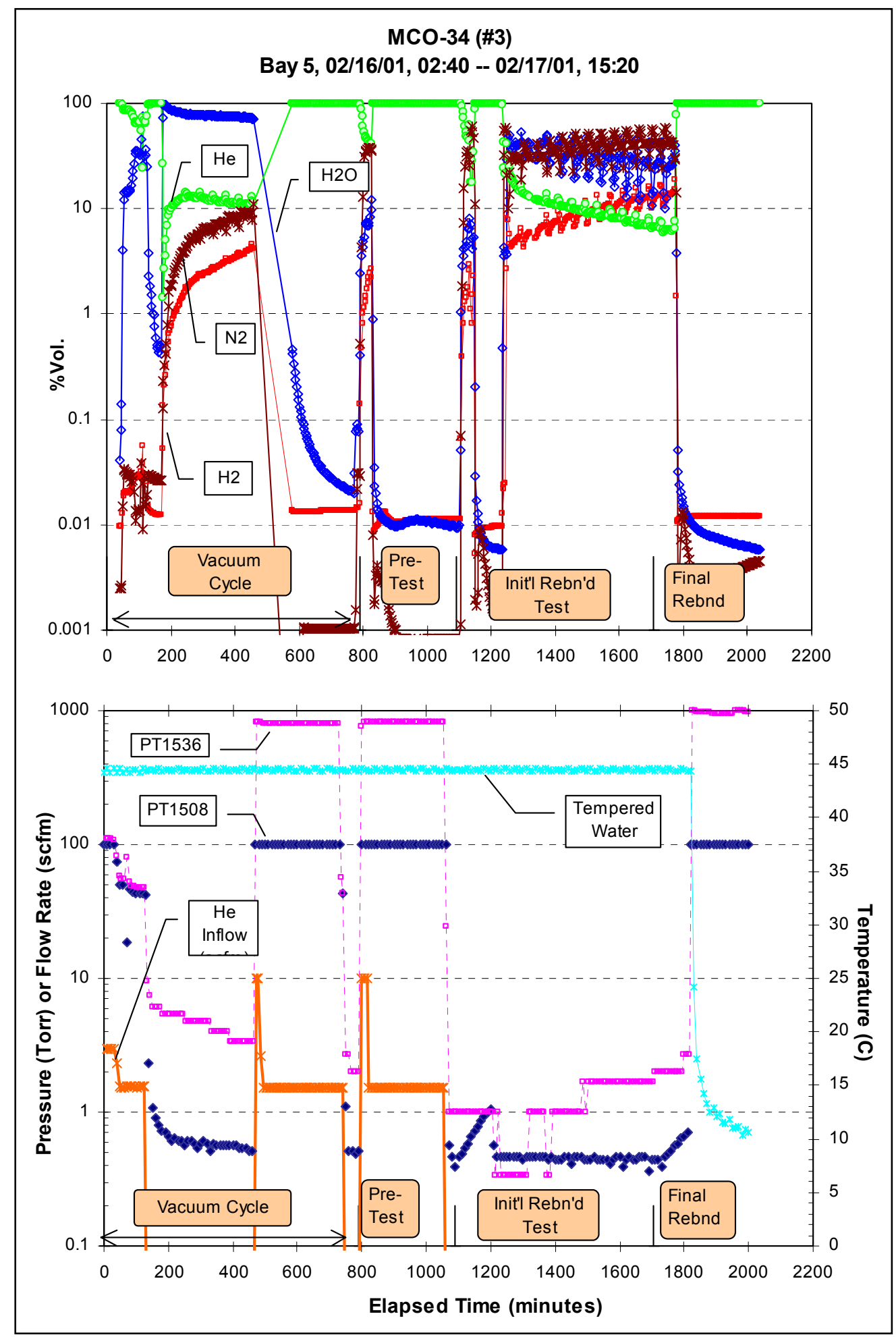

Figure B3.1. Data Overview for MCO-34 Drying Process 


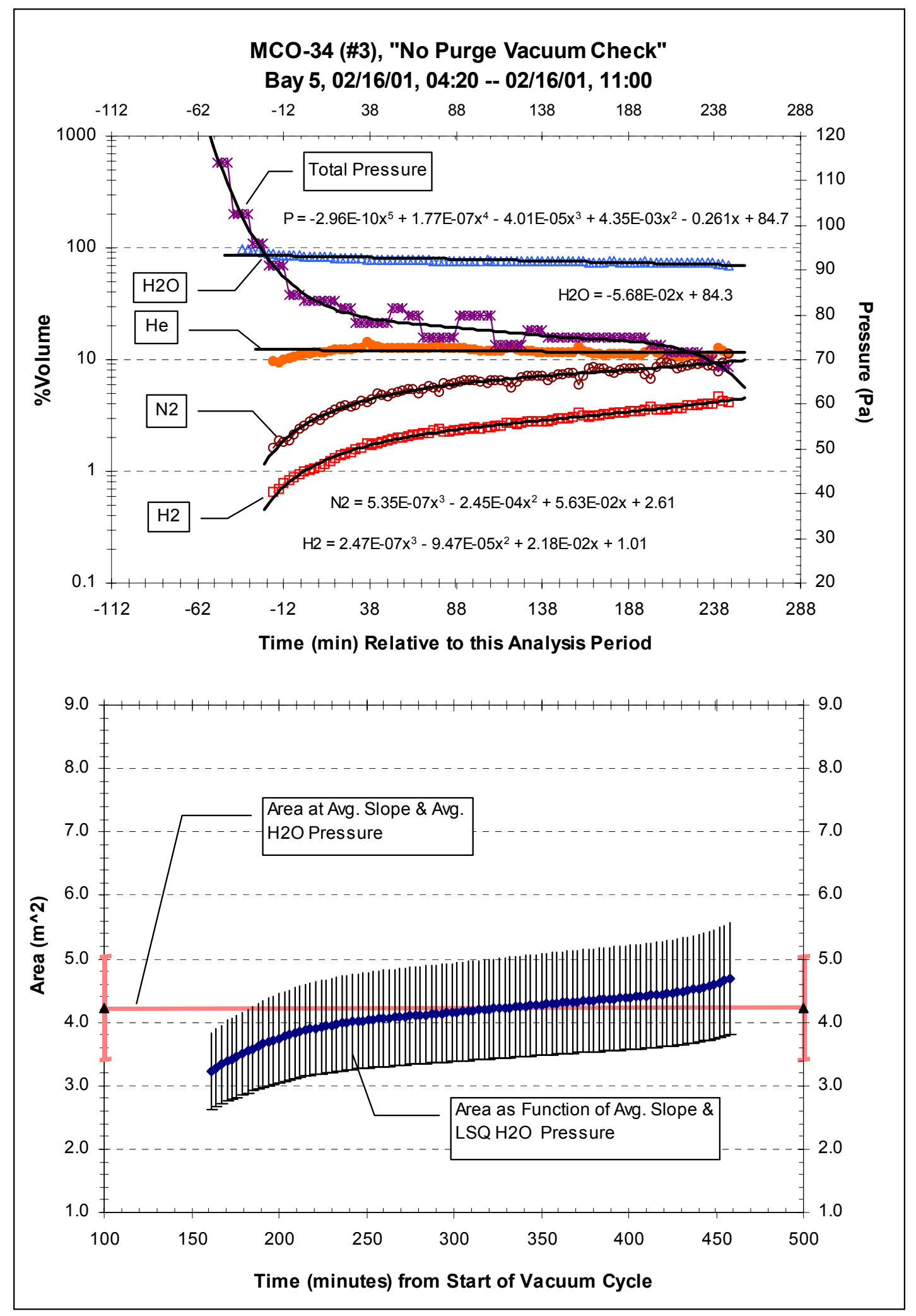

Figure B3.2. Surface Area for First Vacuum Cycle Segment of MCO-34 


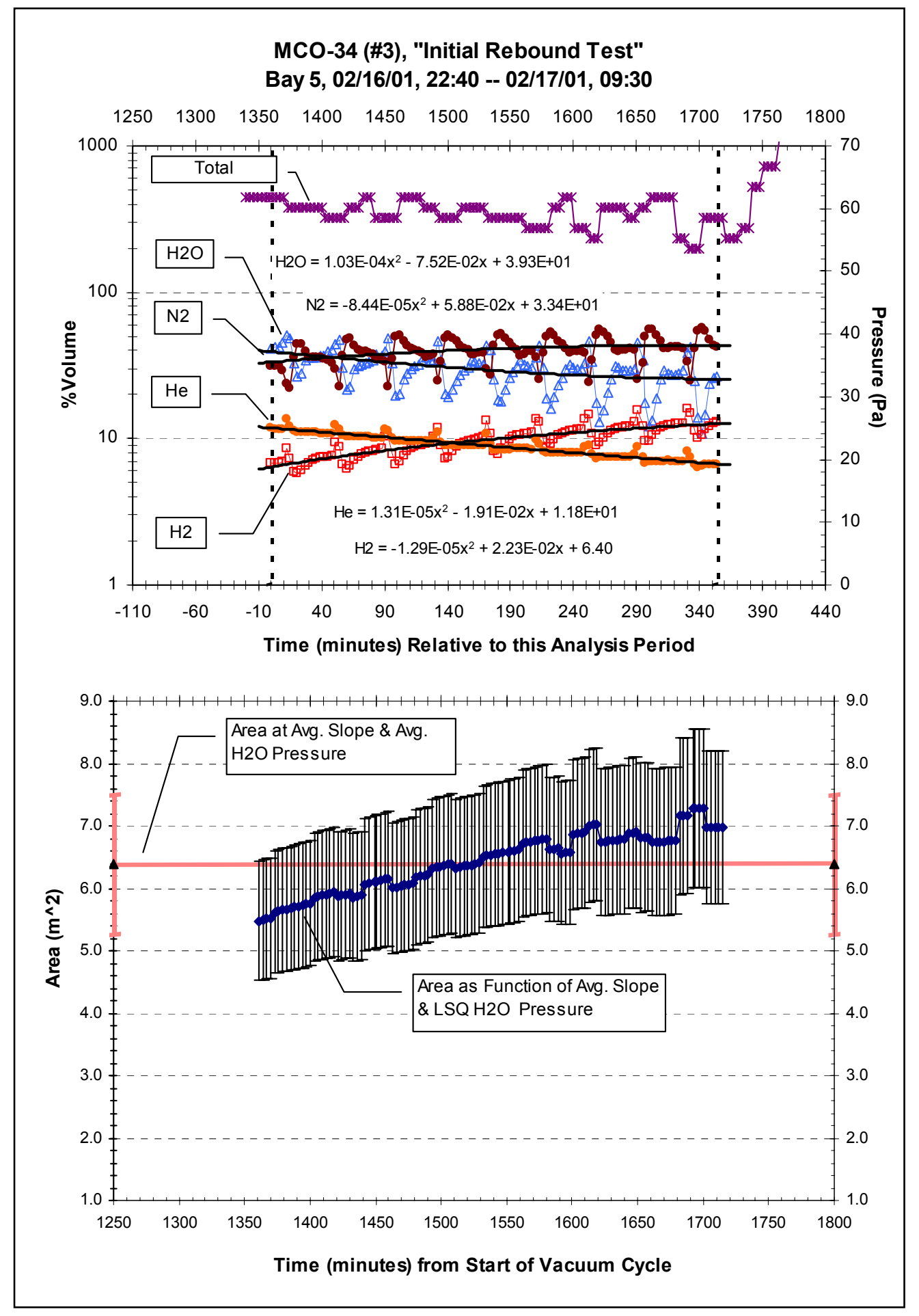

Figure B3.3. Surface Area for IRT Segment of MCO-34 


\section{B.4. MCO-32 (\#5) Drying Process Analysis}

\begin{tabular}{|c|c|c|c|c|c|c|c|c|}
\hline 1 & MCO 32 (Seq.\#5) & & $03 / 15 / 0$ & $\begin{array}{l}\text { cuum } C y \\
14: 19 \text { for }\end{array}$ & $\begin{array}{l}\text { Start Dat } \\
\text { Dry and } 0\end{array}$ & $\begin{array}{l}\text { \& Time } \\
23 / 01,15:\end{array}$ & $\begin{array}{l}\text { DT) } \\
3 \text { for } 2^{\text {nd }} D\end{array}$ & \\
\hline 2 & \multicolumn{2}{|c|}{ Process $\Rightarrow$} & $\begin{array}{c}\text { VacCy- } \\
1\end{array}$ & $\begin{array}{c}\text { VacCy- } \\
2\end{array}$ & $\begin{array}{c}\text { VacCy- } \\
3\end{array}$ & $\begin{array}{l}1^{\text {st }} \text { Dry } \\
\text { Rebnd } \\
\text { Test }\end{array}$ & $\begin{array}{c}2^{\text {nd }} \text { Dry } \\
\text { Rebnd } \\
\text { Test }\end{array}$ & \multirow{4}{*}{$\begin{array}{l}\text { Over All } \\
\text { Averages }\end{array}$} \\
\hline 3 & \multicolumn{2}{|c|}{$\begin{array}{c}\mathbf{t}=0 \text { \& End Pts. for Analysis } \\
\text { (min from SDT) }\end{array}$} & & & & $\begin{array}{l}2051 \& \\
2474\end{array}$ & $\begin{array}{c}596 \& \\
1013\end{array}$ & \\
\hline 4 & \multicolumn{2}{|l|}{ Figure No. $\Rightarrow$} & B4.2 & B4.3 & B4.4 & B4.5 & B4.6 & \\
\hline & Data Type $\Downarrow$ & Units $\downarrow$ & & & & & & \\
\hline 5 & Avg. Temp. & K & $\begin{array}{l}317.60 \\
\pm 0.11 \\
\end{array}$ & $\begin{array}{l}317.63 \\
\pm 0.10 \\
\end{array}$ & $\begin{array}{l}317.59 \\
\pm 0.09 \\
\end{array}$ & $\begin{array}{l}317.62 \\
\pm 0.10 \\
\end{array}$ & $\begin{array}{l}317.60 \\
\pm 0.10 \\
\end{array}$ & $\begin{array}{l}317.61 \\
\pm 0.04 \\
\end{array}$ \\
\hline 6 & $\begin{array}{l}\text { Avg. Total } \\
\text { Press. }\end{array}$ & $\mathrm{Pa}$ & $\begin{array}{l}120.41 \\
\pm 14.86\end{array}$ & $\begin{array}{l}72.36 \\
\pm 2.32\end{array}$ & $\begin{array}{l}65.40 \\
\pm 3.10\end{array}$ & $\begin{array}{l}56.09 \\
\pm 1.94\end{array}$ & $\begin{array}{l}53.69 \\
\pm 1.81\end{array}$ & $\begin{array}{l}60.20 \\
\pm 1.08\end{array}$ \\
\hline 7 & Avg. Total Moles & mMoles & $\begin{array}{l}32.37 \\
\pm 4.00\end{array}$ & $\begin{array}{c}19.45 \\
\pm 0.62\end{array}$ & $\begin{array}{r}17.58 \\
\pm 0.83\end{array}$ & $\begin{array}{l}15.07 \\
\pm 0.52\end{array}$ & $\begin{array}{c}14.43 \\
\pm 0.49\end{array}$ & $\begin{array}{c}16.18 \\
\pm 0.29\end{array}$ \\
\hline 8 & $\begin{array}{l}\text { Vacuum Pump } \\
\text { OutFlow Rate }\end{array}$ & $\begin{array}{l}\text { mMoles } \\
\text { per min }\end{array}$ & $\begin{array}{r}37.89 \\
\pm 5.60\end{array}$ & $\begin{array}{r}19.78 \\
\pm 0.87\end{array}$ & $\begin{array}{r}17.16 \\
\pm 1.17\end{array}$ & $\begin{array}{r}13.64 \\
\pm 0.73\end{array}$ & $\begin{array}{c}12.74 \\
\pm 0.68\end{array}$ & $\begin{array}{r}15.19 \\
\pm 0.41\end{array}$ \\
\hline 9 & $\mathrm{~N}_{2} \quad$ Avg. \%vol. & $\%$ & $\begin{array}{c}1.37 \\
\pm 0.38 \\
\end{array}$ & $\begin{array}{c}6.56 \\
\pm 0.81 \\
\end{array}$ & $\begin{array}{c}1.88 \\
\pm 1.84 \\
\end{array}$ & $\begin{array}{r}43.57 \\
\pm 8.72 \\
\end{array}$ & $\begin{array}{r}60.47 \\
\pm 5.91 \\
\end{array}$ & $\begin{array}{r}2.55 \\
\pm 0.34 \\
\end{array}$ \\
\hline 10 & He Avg. \%vol. & $\%$ & $\begin{array}{r}10.68 \\
\pm 2.01\end{array}$ & $\begin{array}{l}21.12 \\
\pm 0.82\end{array}$ & $\begin{array}{l}22.77 \\
\pm 0.93\end{array}$ & $\begin{array}{l}21.47 \\
\pm 1.18\end{array}$ & $\begin{array}{c}18.58 \\
\pm 6.24\end{array}$ & $\begin{array}{l}20.99 \\
\pm 0.52\end{array}$ \\
\hline 11 & $\mathrm{H}_{2} \mathrm{O}$ Avg. \%vol. & $\%$ & $\begin{array}{r}86.58 \\
\pm 2.59\end{array}$ & $\begin{array}{r}68.20 \\
\pm 1.29\end{array}$ & $\begin{array}{l}59.80 \\
\pm 2.26\end{array}$ & $\begin{array}{c}16.41 \\
\pm 7.94\end{array}$ & $\begin{array}{c}2.81 \\
\pm 0.95\end{array}$ & $\begin{array}{l}33.32 \\
\pm 0.69\end{array}$ \\
\hline 12 & $\mathrm{H}_{2} \quad$ Avg. \%vol. & $\%$ & $\begin{array}{c}0.71 \\
\pm 0.12\end{array}$ & $\begin{array}{c}2.07 \\
\pm 0.18\end{array}$ & $\begin{array}{c}2.95 \\
\pm 0.21\end{array}$ & $\begin{array}{c}6.73 \\
\pm 2.68\end{array}$ & $\begin{array}{c}2.14 \\
\pm 2.07\end{array}$ & $\begin{array}{c}1.45 \\
\pm 0.09\end{array}$ \\
\hline 13 & $\begin{array}{l}\text { Avg. } \\
\mathrm{H}_{2} \text {-LSQ Slope }\end{array}$ & $\mu \mathrm{g} / \mathrm{min}$ & $\begin{array}{c}1.55 \\
\pm 0.04\end{array}$ & $\begin{array}{c}1.80 \\
\pm 0.21\end{array}$ & $\begin{array}{c}2.76 \\
\pm 0.35\end{array}$ & $\begin{array}{c}0.58 \\
\pm 0.56\end{array}$ & $\begin{array}{c}0.26 \\
\pm 0.44\end{array}$ & $\begin{array}{c}1.56 \\
\pm 0.04\end{array}$ \\
\hline 14 & $\begin{array}{l}\text { Avg. } \mathrm{H}_{2} 0 \\
\text { Removal Rate }\end{array}$ & $\mathrm{g} / \mathrm{h}$ & $\begin{array}{c}0.21 \\
\pm 0.08\end{array}$ & $\begin{array}{c}0.05 \\
\pm 0.06\end{array}$ & $\begin{array}{c}0.03 \\
\pm 0.05\end{array}$ & $\begin{array}{c}0.004 \\
\pm 0.011\end{array}$ & $\begin{array}{c}0.001 \\
\pm 0.002\end{array}$ & $\begin{array}{c}0.06 \\
\pm 0.20\end{array}$ \\
\hline 15 & $\begin{array}{l}\text { Avg. Air } \\
\text { Inleak Rate }\end{array}$ & $\mathrm{mL} / \mathrm{h}$ & $\begin{array}{l}0.03 \\
\pm 0.01\end{array}$ & $\begin{array}{c}0.14 \\
\pm 0.04\end{array}$ & $\begin{array}{c}0.04 \\
\pm 0.01\end{array}$ & $\begin{array}{c}0.94 \\
\pm 0.19\end{array}$ & $\begin{array}{c}1.30 \\
\pm 0.26\end{array}$ & $\begin{array}{c}0.49 \\
\pm 0.49\end{array}$ \\
\hline 16 & $\begin{array}{l}\text { Avg. } \\
\text { Reactive Area }\end{array}$ & $\mathrm{m}^{2}$ & $\begin{array}{c}0.72 \\
\pm 0.12\end{array}$ & $\begin{array}{c}1.22 \\
\pm 0.17\end{array}$ & $\begin{array}{c}2.10 \\
\pm 0.30\end{array}$ & $\begin{array}{c}0.90 \\
\pm 0.88\end{array}$ & $\begin{array}{c}1.02 \\
\pm 1.72\end{array}$ & $\begin{array}{c}1.00 \\
\pm 0.09\end{array}$ \\
\hline
\end{tabular}




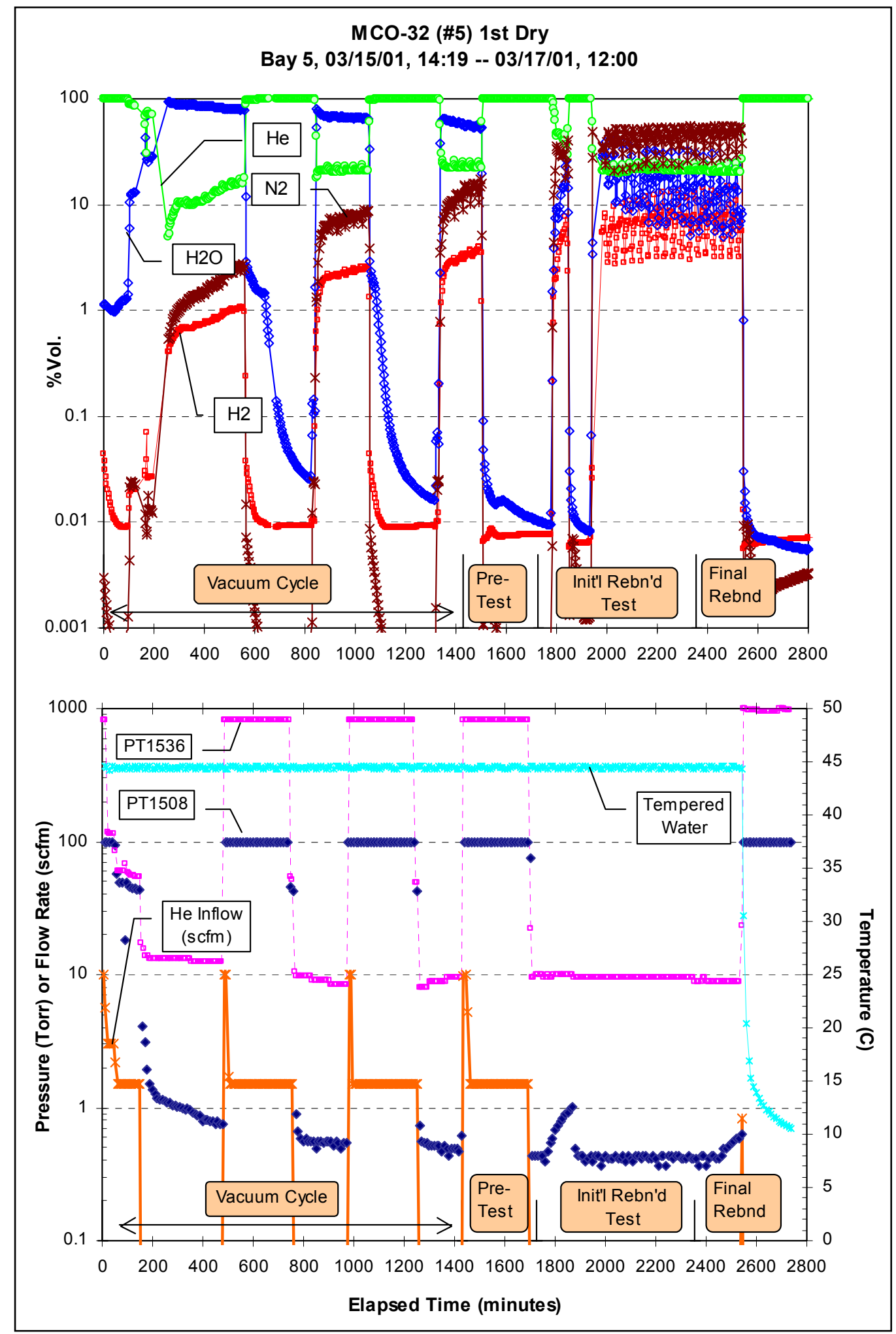

Figure B4.1. Data Overview for MCO-32 Drying Process 


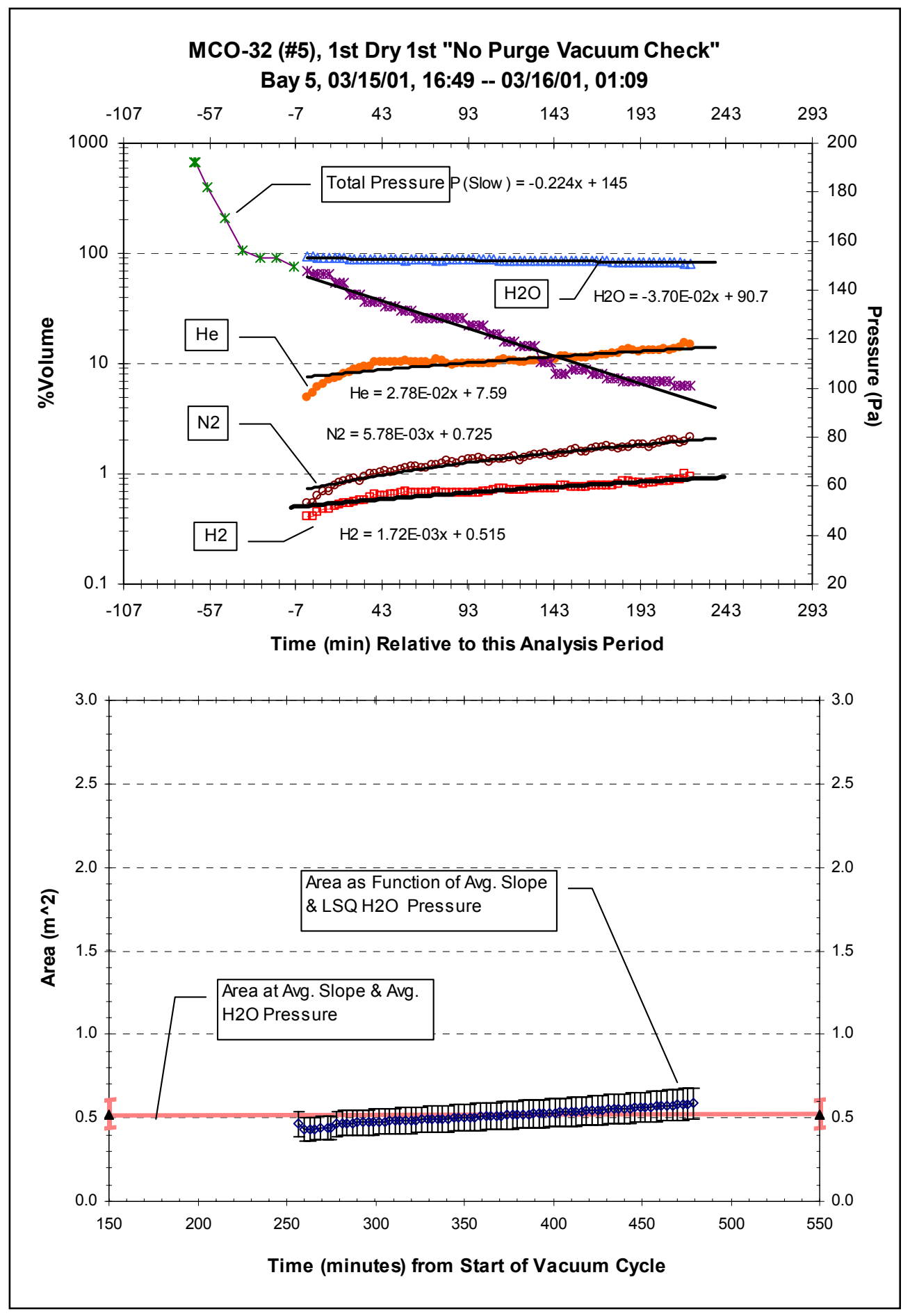

Figure B4.2. Surface Area for Vacuum Cycle 1 Segment of MCO-32 


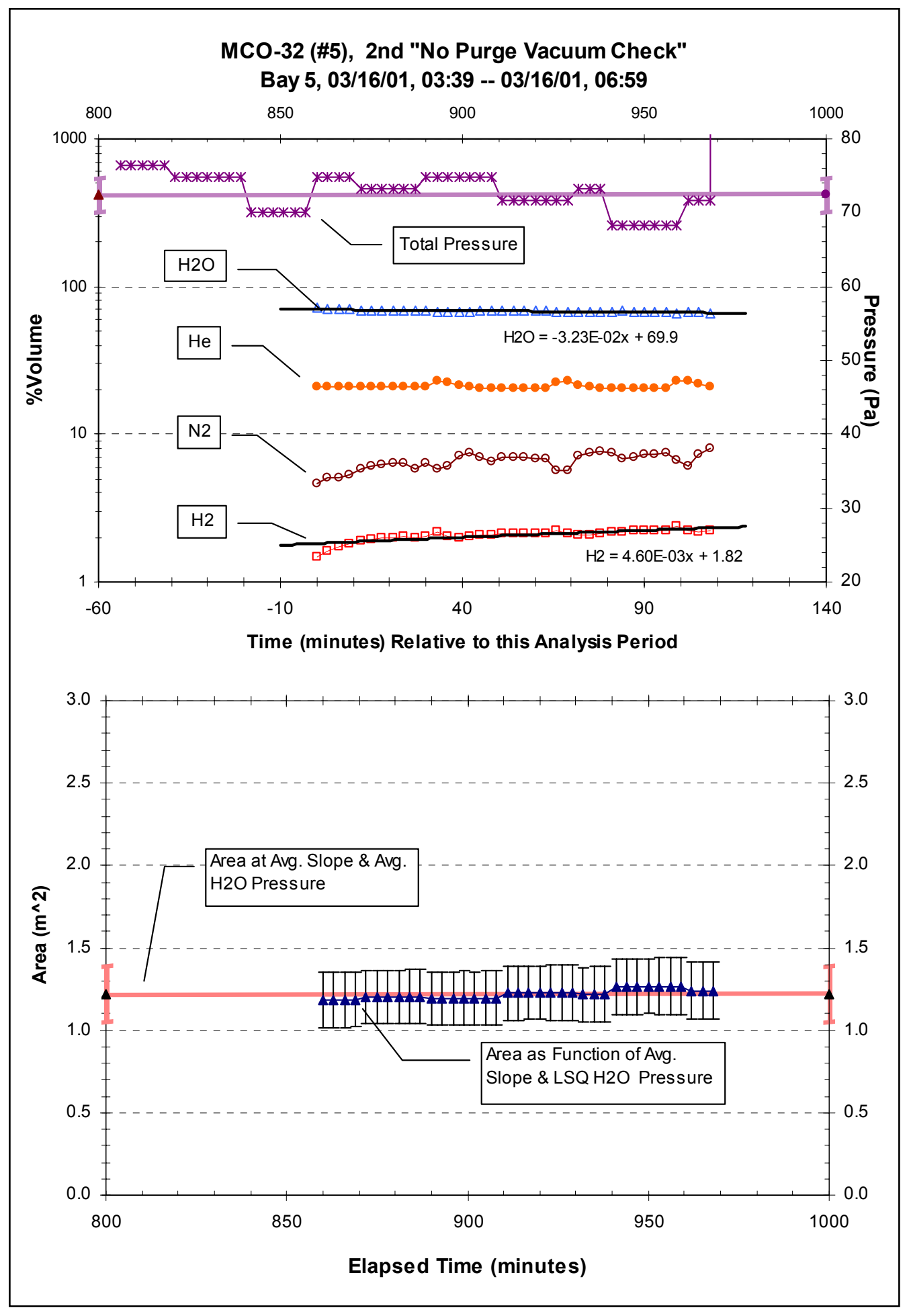

Figure B4.3. Surface Area for Vacuum Cycle 2 Segment of MCO-32 


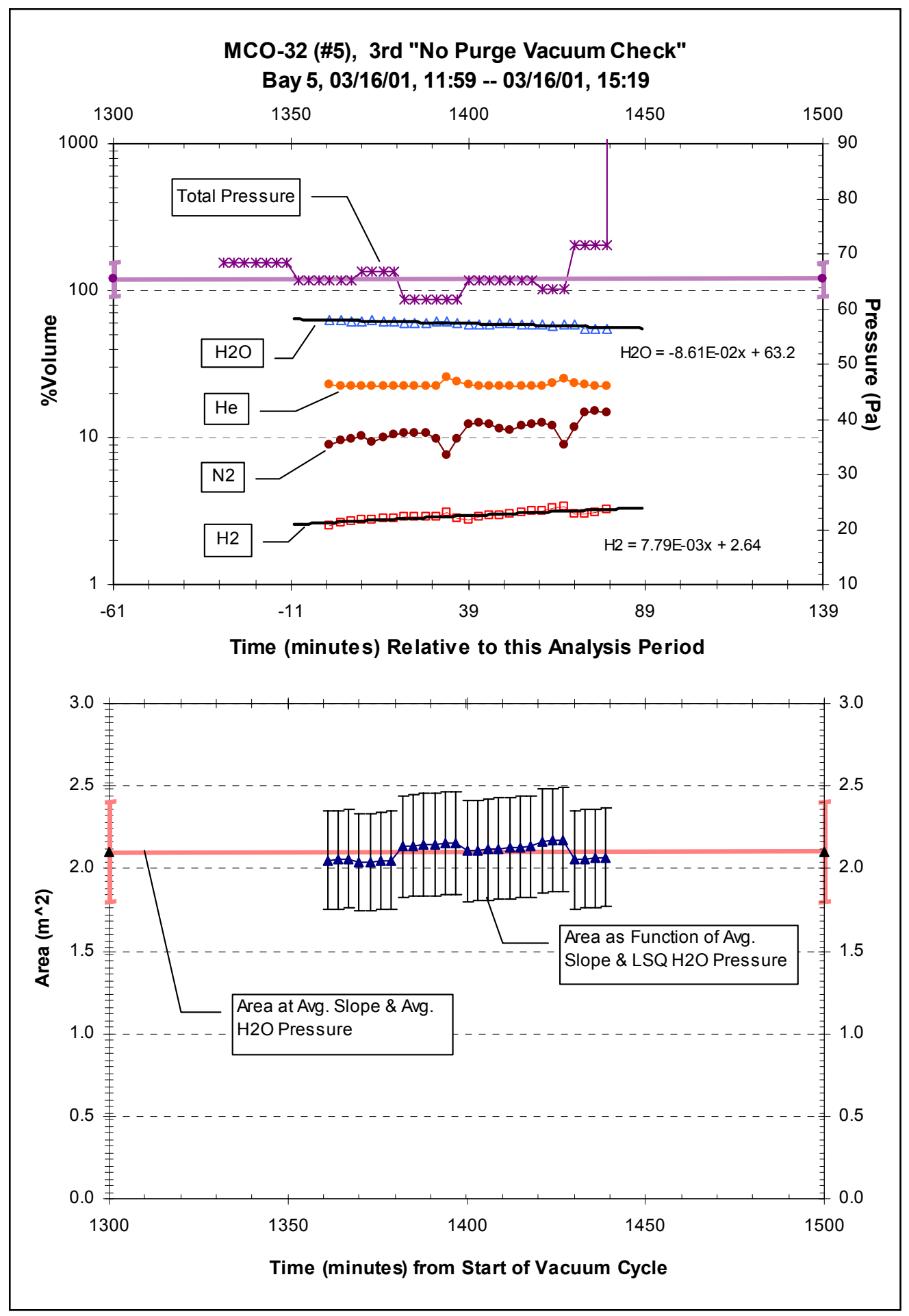

Figure B4.4. Surface Area Third Vacuum Cycle Segment of MCO-32 


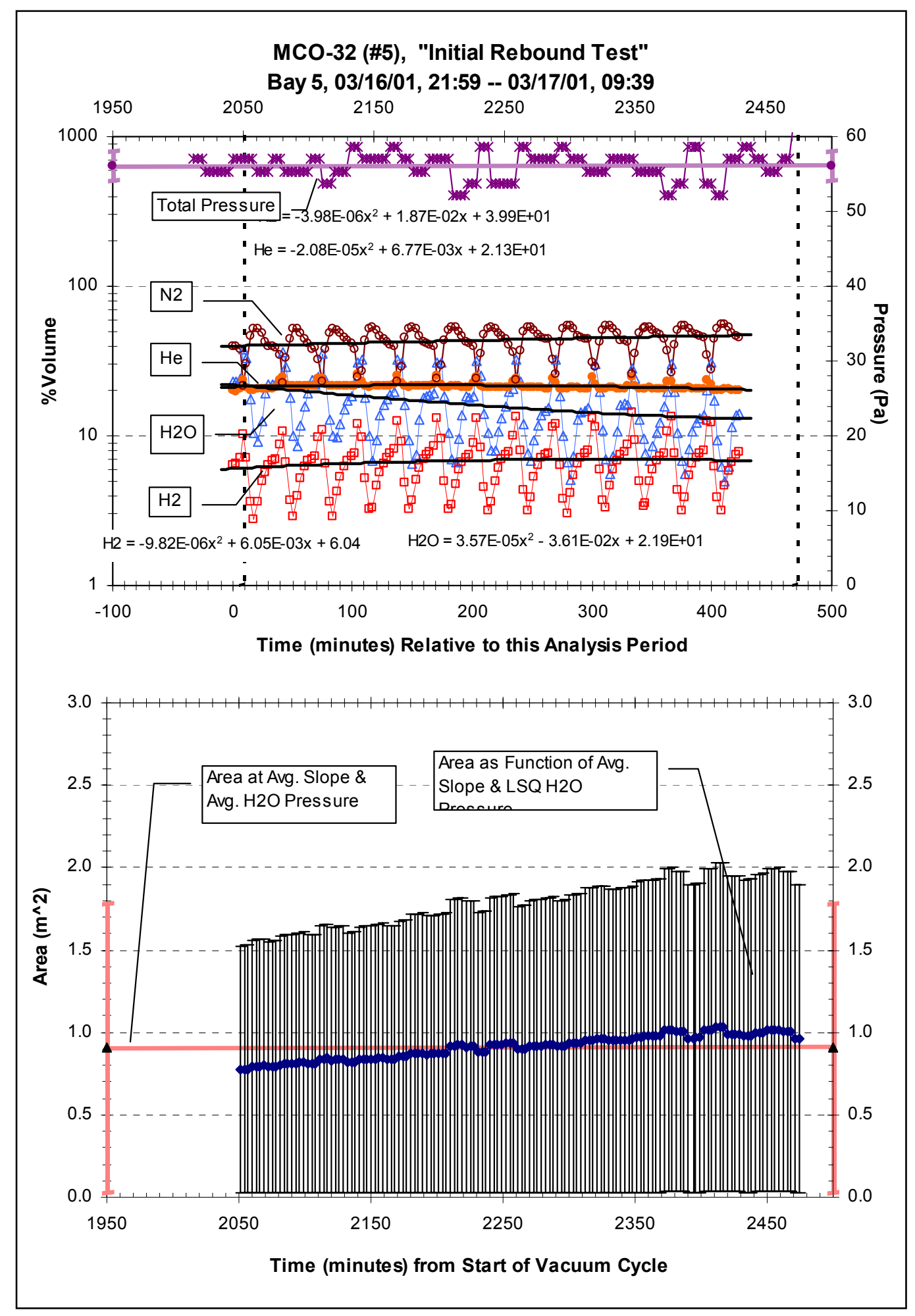

Figure B4.5. Surface Area for IRT Segment of MCO-32 


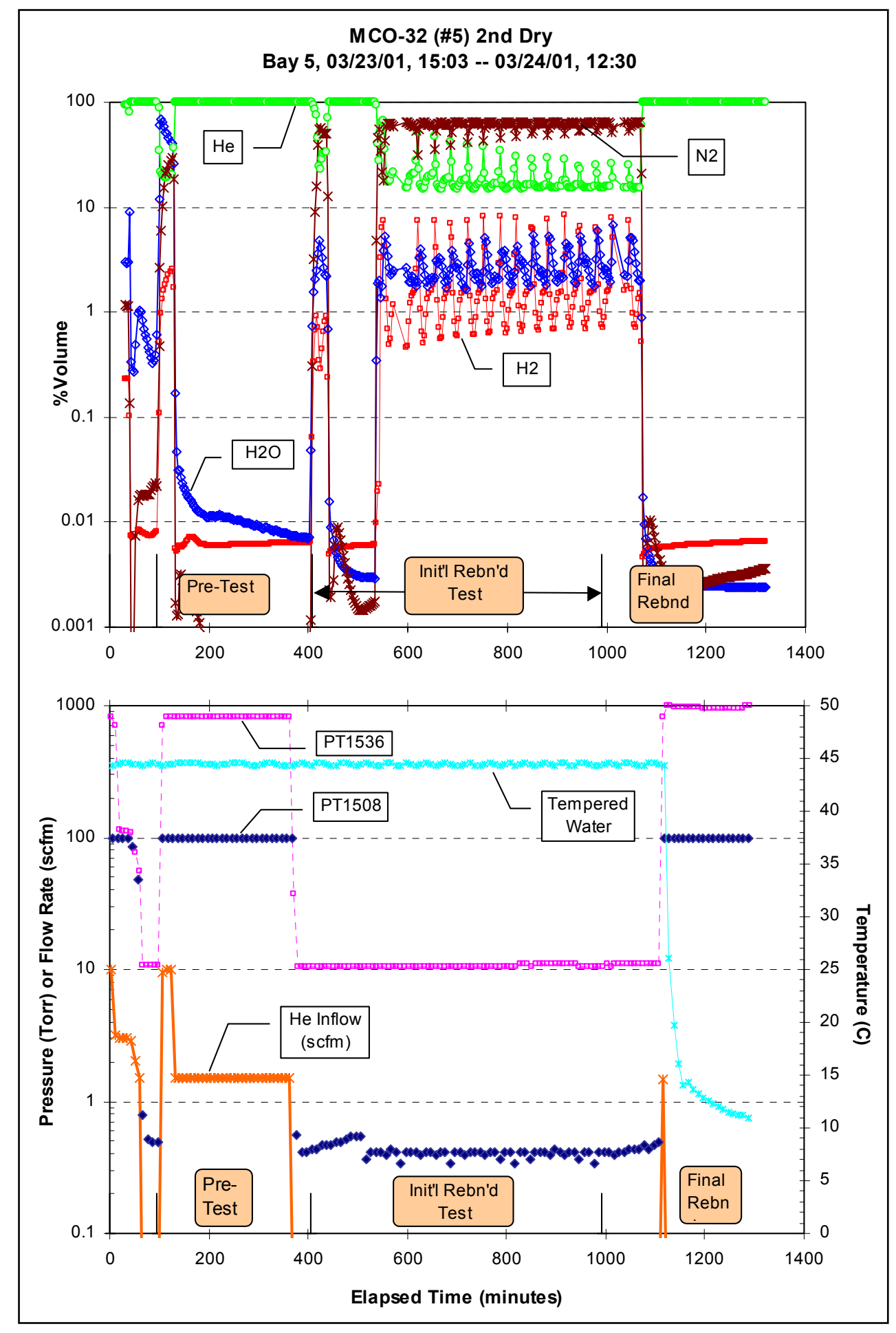

Figure B4.6. Data Overview for MCO-32 Re-Drying 


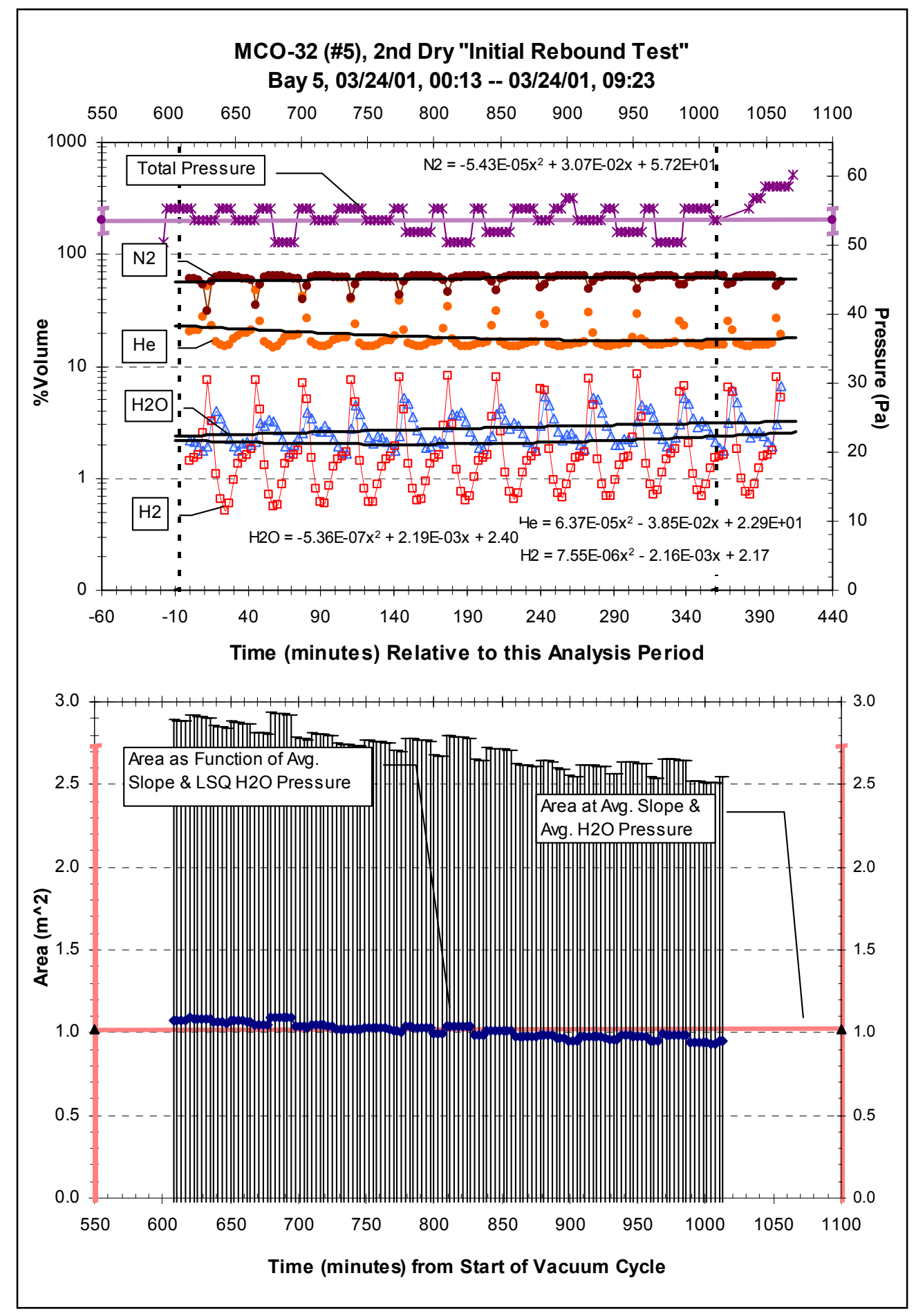

Figure B4.7. Surface Area for IRT Segment of MCO-32 Re-Dry 


\section{B.5. MCO-69 (\#6) Drying Process Analysis}

\begin{tabular}{|c|c|c|c|c|c|c|c|}
\hline 1 & $\begin{array}{l}\text { MCO } 69 \\
\text { (Seq.\#6) }\end{array}$ & & Vacuun & $\begin{array}{r}\text { Cycle Star } \\
05 / 02 /\end{array}$ & $\begin{array}{l}\text { Date } \boldsymbol{\&} \\
1,12: 59\end{array}$ & $\overline{\text { me }\left(\mathrm{SD}^{\prime}\right.}$ & \multirow{5}{*}{$\begin{array}{l}\text { Over All } \\
\text { Averages }\end{array}$} \\
\hline 2 & \multicolumn{2}{|c|}{ Process $\Rightarrow$} & $\begin{array}{c}\text { VacCy- } \\
1\end{array}$ & $\begin{array}{c}\text { VacCy- } \\
2\end{array}$ & $\begin{array}{c}\text { VacCy- } \\
3\end{array}$ & $\begin{array}{l}\text { Rebnd } \\
\text { Test }\end{array}$ & \\
\hline 3 & \multicolumn{2}{|c|}{$\begin{array}{c}\mathrm{t}=0 \text { \& End Pts. for Analysis } \\
(\text { min from SDT) }\end{array}$} & & & & $\begin{array}{c}\text { No } \\
\text { RGA } \\
\text { Data }\end{array}$ & \\
\hline 4 & \multicolumn{2}{|l|}{ Figure No. $\Rightarrow$} & B5.2 & B5.3 & B5.4 & & \\
\hline & "Data Type $\Downarrow$ & Units $\downarrow$ & & & & & \\
\hline 5 & Avg. Temp. & $\mathrm{K}$ & $\begin{array}{l}317.61 \\
\pm 0.11\end{array}$ & $\begin{array}{l}317.58 \\
\pm 0.10\end{array}$ & $\begin{array}{l}317.63 \\
\pm 0.11\end{array}$ & & $\begin{array}{l}317.60 \\
\pm 0.06\end{array}$ \\
\hline 6 & Avg. Total Press. & $\mathrm{Pa}$ & $\begin{array}{l}97.81 \\
\pm 15.11\end{array}$ & $\begin{array}{r}76.58 \\
\pm 4.16\end{array}$ & $\begin{array}{l}65.74 \\
\pm 1.95\end{array}$ & & $\begin{array}{l}68.09 \\
\pm 1.75\end{array}$ \\
\hline 7 & Avg. Total Moles & mMoles & $\begin{array}{l}26.30 \\
\pm 4.06\end{array}$ & $\begin{array}{l}20.59 \\
\pm 1.12\end{array}$ & $\begin{array}{r}17.67 \\
\pm 0.52\end{array}$ & & $\begin{array}{l}18.31 \\
\pm 0.47\end{array}$ \\
\hline 8 & $\begin{array}{l}\text { Vacuum Pump } \\
\text { OutFlow Rate }\end{array}$ & $\begin{array}{l}\text { mMoles } \\
\text { per min }\end{array}$ & $\begin{array}{l}29.37 \\
\pm 5.70\end{array}$ & $\begin{array}{r}21.37 \\
\pm 1.57\end{array}$ & $\begin{array}{r}17.28 \\
\pm 0.73\end{array}$ & & $\begin{array}{l}18.17 \\
\pm 0.66\end{array}$ \\
\hline 9 & $\mathrm{~N}_{2} \quad$ Avg. \%vol. & $\%$ & $\begin{array}{c}2.43 \\
\pm 0.88\end{array}$ & $\begin{array}{r}5.22 \\
\pm 0.45\end{array}$ & $\begin{array}{r}7.18 \\
\pm 1.74\end{array}$ & & $\begin{array}{r}4.78 \\
\pm 0.39\end{array}$ \\
\hline 10 & He Avg. \%vol. & $\%$ & $\begin{array}{r}16.79 \\
\pm 3.17\end{array}$ & $\begin{array}{r}16.71 \\
\pm 0.59\end{array}$ & $\begin{array}{r}18.91 \\
\pm 0.63\end{array}$ & & $\begin{array}{r}17.72 \\
\pm 0.43\end{array}$ \\
\hline 11 & $\mathrm{H}_{2} \mathrm{O}$ Avg. \%vol. & $\%$ & $\begin{array}{r}78.33 \\
\pm 4.19\end{array}$ & $\begin{array}{r}76.30 \\
\pm 2.29\end{array}$ & $\begin{array}{r}70.27 \\
\pm 2.55\end{array}$ & & $\begin{array}{l}74.27 \\
\pm 1.58\end{array}$ \\
\hline 12 & $\mathrm{H}_{2} \quad$ Avg. \%vol. & $\%$ & $\begin{array}{r}1.65 \\
\pm 0.42\end{array}$ & $\begin{array}{r}1.34 \\
\pm 0.28\end{array}$ & $\begin{array}{r}1.70 \\
\pm 0.37\end{array}$ & & $\begin{array}{c}1.51 \\
\pm 0.20\end{array}$ \\
\hline 13 & $\begin{array}{l}\text { Avg. } \\
\mathrm{H}_{2} \text {-LSQ Slope }\end{array}$ & $\mu \mathrm{g} / \mathrm{min}$ & $\begin{array}{r}2.87 \\
\pm 0.17\end{array}$ & $\begin{array}{r}2.22 \\
\pm 0.17\end{array}$ & $\begin{array}{c}6.19 \\
\pm 0.45\end{array}$ & & $\begin{array}{c}2.79 \\
\pm 0.12\end{array}$ \\
\hline 14 & $\begin{array}{l}\text { Avg. } \mathrm{H}_{2} \mathrm{O} \\
\text { Removal Rate }\end{array}$ & $\mathrm{g} / \mathrm{h}$ & $\begin{array}{r}0.49 \\
\pm 0.28 \\
\end{array}$ & $\begin{array}{r}0.26 \\
\pm 0.19 \\
\end{array}$ & $\begin{array}{r}0.14 \\
\pm 0.13 \\
\end{array}$ & & $\begin{array}{r}0.30 \\
\pm 0.61 \\
\end{array}$ \\
\hline 15 & $\begin{array}{l}\text { Avg. Air } \\
\text { Inleak Rate }\end{array}$ & $\mathrm{mL} / \mathrm{h}$ & $\begin{array}{l}0.10 \\
\pm 0.02\end{array}$ & $\begin{array}{c}0.22 \\
\pm 0.04\end{array}$ & $\begin{array}{c}0.31 \\
\pm 0.06\end{array}$ & & $\begin{array}{c}0.21 \\
\pm 0.13\end{array}$ \\
\hline 16 & $\begin{array}{l}\text { Avg. } \\
\text { Reactive Area }\end{array}$ & $\mathrm{m}^{2}$ & $\begin{array}{r}1.55 \\
\pm 0.33\end{array}$ & $\begin{array}{r}1.38 \\
\pm 0.15\end{array}$ & $\begin{array}{r}4.33 \\
\pm 0.35\end{array}$ & & $\begin{array}{r}1.81 \\
\pm 0.13\end{array}$ \\
\hline
\end{tabular}




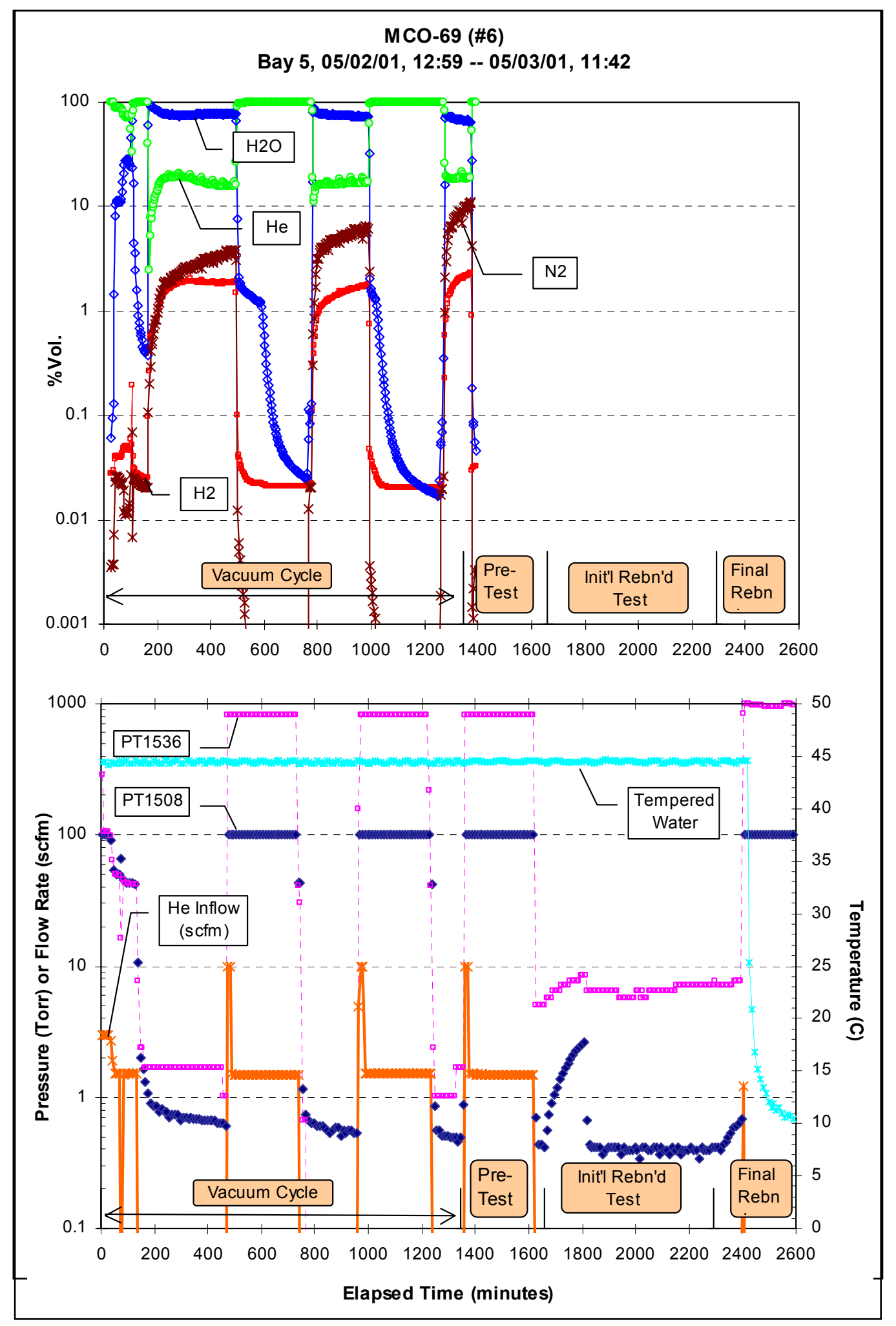

Figure B5.1. Data Overview for MCO-69 Drying Process 


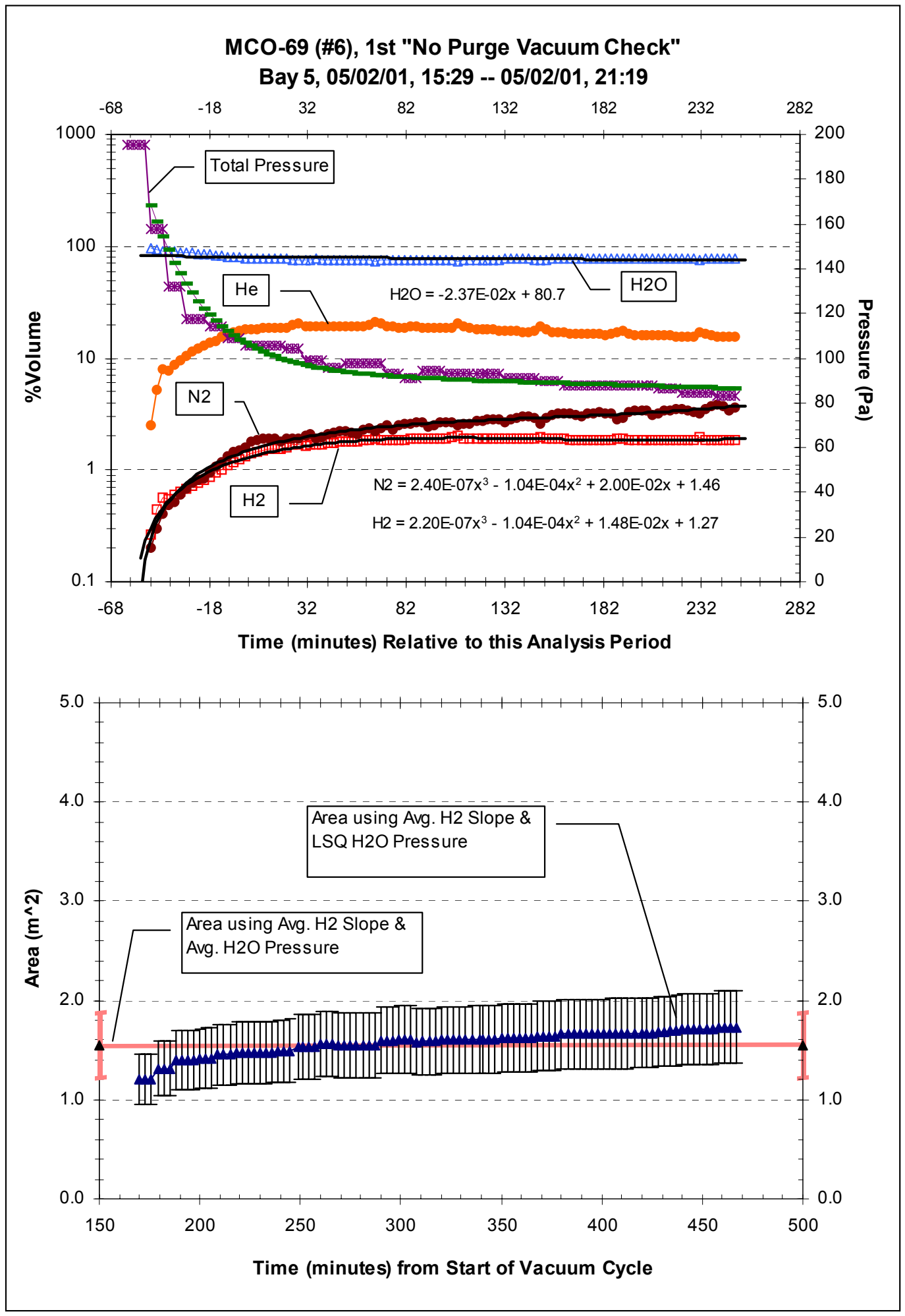

Figure B5.2. Surface Area for Vacuum Cycle 1 Segment of MCO-69 

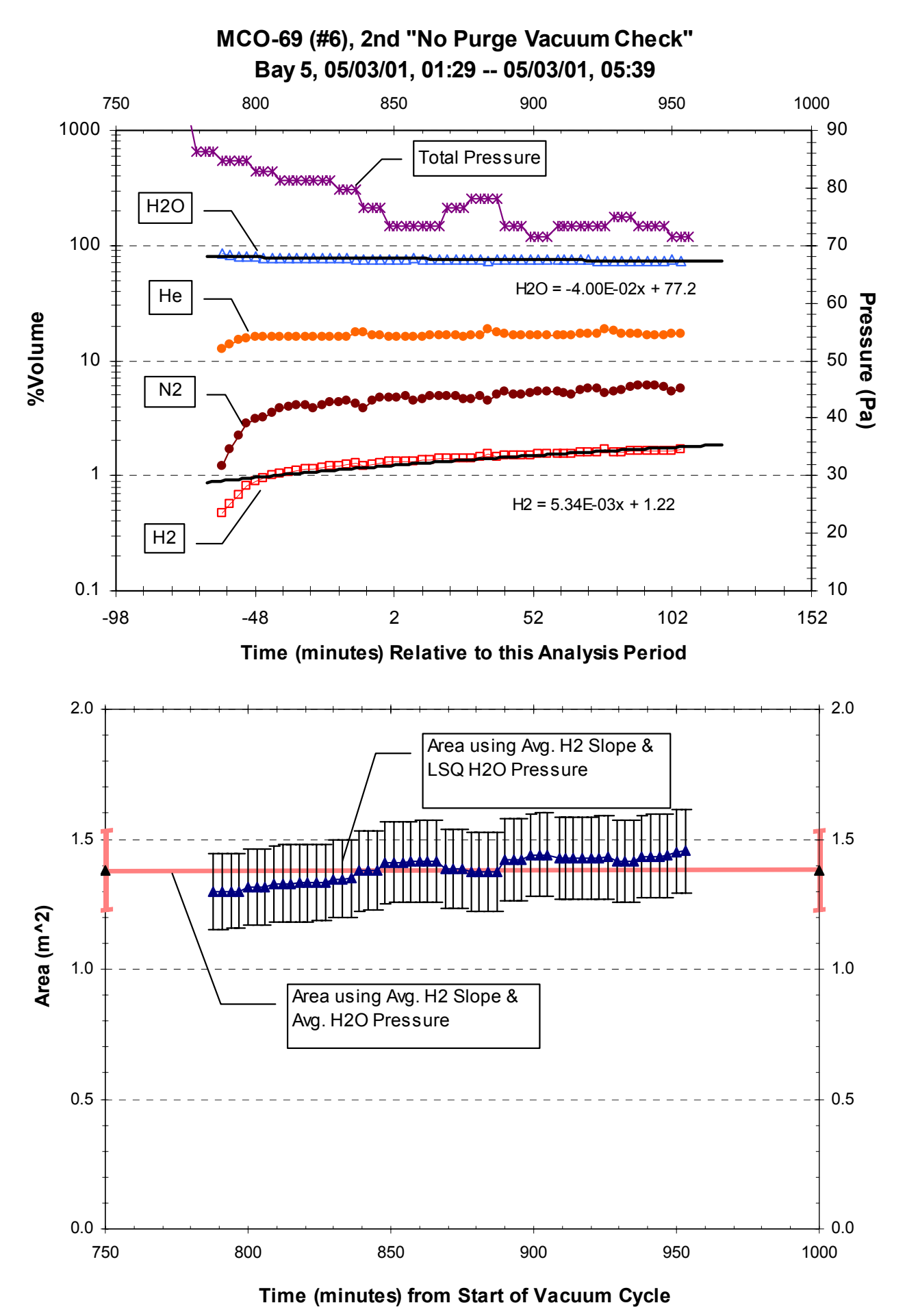

Figure B5.3. Surface Area for Vacuum Cycle 2 Segment of MCO-69 


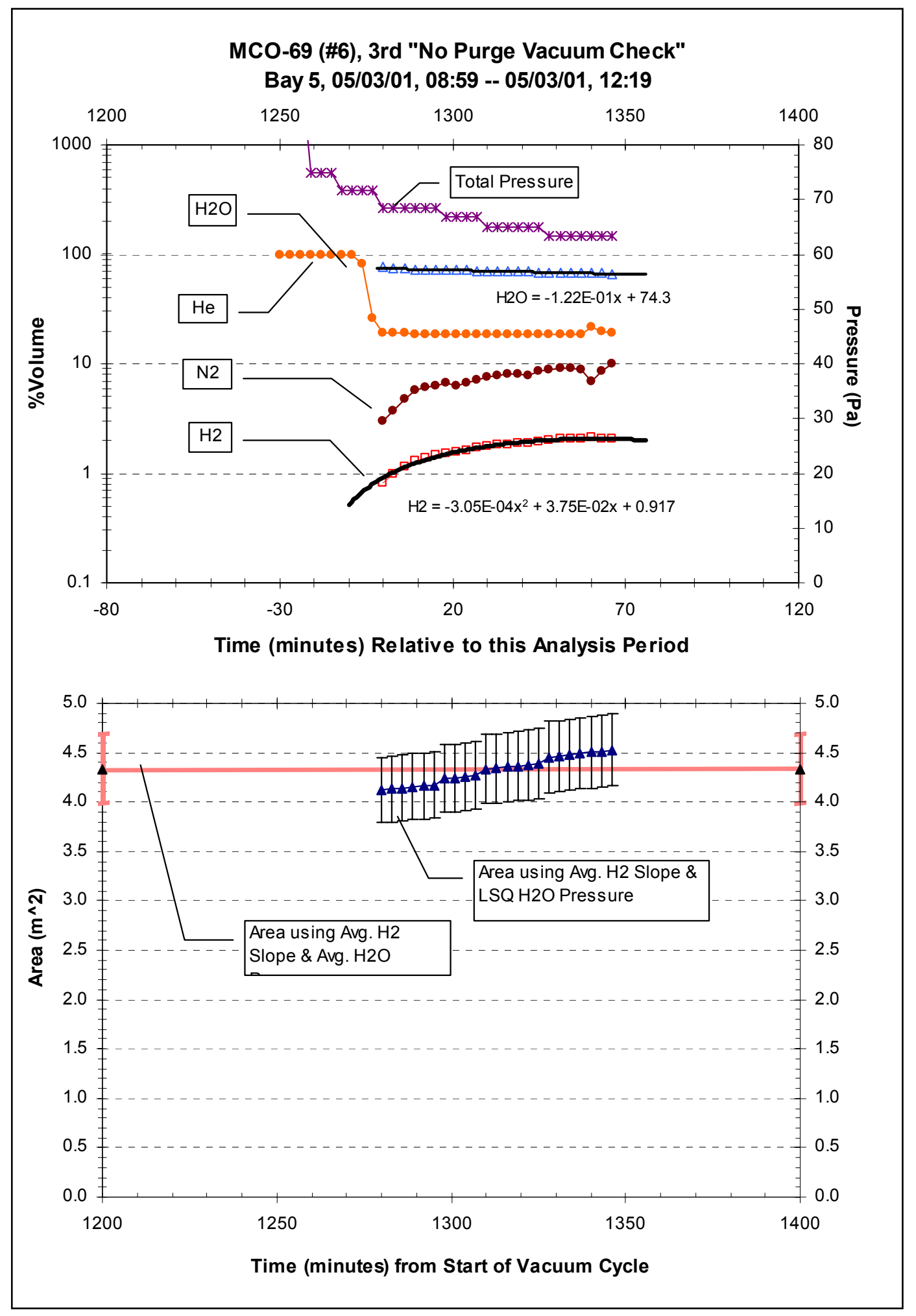

Figure B5.4. Surface Area for Vacuum Cycle 3 Segment of MCO-69 


\section{B.6. MCO-89 (\#8) Drying Process Analysis}

\begin{tabular}{|c|c|c|c|c|c|c|c|}
\hline 1 & $\begin{array}{c}\text { MCO 89 } \\
\text { (Seq.\#8) }\end{array}$ & & Vacuun & $\begin{array}{r}\text { Cycle Sta } \\
05 / 17\end{array}$ & $\begin{array}{l}\text { Date } \boldsymbol{\&} \\
1,12: 04\end{array}$ & ne (SDT & \multirow{5}{*}{$\begin{array}{l}\text { Over All } \\
\text { Averages } \\
\text { (omitting } \\
\text { VacCy-3) }\end{array}$} \\
\hline 2 & \multicolumn{2}{|c|}{ Process $\Rightarrow$} & $\begin{array}{c}\text { VacCy- } \\
1\end{array}$ & $\begin{array}{c}\text { VacCy- } \\
2\end{array}$ & $\begin{array}{l}\text { VacCy- } \\
3\end{array}$ & $\begin{array}{l}\text { Rebnd } \\
\text { Test }\end{array}$ & \\
\hline 3 & \multicolumn{2}{|c|}{$\begin{array}{c}\mathrm{t}=0 \text { \& End Pts. for Analysis } \\
(\text { min from SDT) }\end{array}$} & & & & & \\
\hline 4 & \multicolumn{2}{|l|}{ Figure No. $\Rightarrow$} & B6.2 & B6.3 & B6.4 & B6.5 & \\
\hline & Data Type $\Downarrow$ & Units $\Downarrow$ & & & & & \\
\hline 5 & Avg. Temp. & $\mathrm{K}$ & $\begin{array}{l}317.61 \\
\pm 0.11\end{array}$ & $\begin{array}{l}317.60 \\
\pm 0.11\end{array}$ & $\begin{array}{l}317.57 \\
\pm 0.10\end{array}$ & $\begin{array}{l}317.66 \\
\pm 0.09\end{array}$ & $\begin{array}{l}317.63 \\
\pm 0.06\end{array}$ \\
\hline 6 & $\begin{array}{l}\text { Avg. Total } \\
\text { Press. }\end{array}$ & $\mathrm{Pa}$ & $\begin{array}{l}121.52 \\
\pm 39.05\end{array}$ & $\begin{array}{r}66.26 \\
\pm 1.91\end{array}$ & $\begin{array}{l}65.51 \\
\pm 1.15\end{array}$ & $\begin{array}{l}54.85 \\
\pm 1.25\end{array}$ & $\begin{array}{r}58.34 \\
\pm 1.05\end{array}$ \\
\hline 7 & Avg. Total Moles & mMoles & $\begin{array}{r}32.67 \\
\pm 10.50\end{array}$ & $\begin{array}{r}17.82 \\
\pm 0.51\end{array}$ & $\begin{array}{r}17.61 \\
\pm 0.31\end{array}$ & $\begin{array}{r}14.74 \\
\pm 0.34\end{array}$ & $\begin{array}{r}15.68 \\
\pm 0.28\end{array}$ \\
\hline 8 & $\begin{array}{l}\text { Vacuum Pump } \\
\text { OutFlow Rate }\end{array}$ & $\begin{array}{l}\text { mMoles } \\
\text { per min }\end{array}$ & $\begin{array}{r}38.31 \\
\pm 14.72\end{array}$ & $\begin{array}{r}17.48 \\
\pm 0.72\end{array}$ & $\begin{array}{r}17.20 \\
\pm 0.43\end{array}$ & $\begin{array}{l}13.18 \\
\pm 0.47\end{array}$ & $\begin{array}{r}14.49 \\
\pm 0.40\end{array}$ \\
\hline 9 & $\mathrm{~N}_{2} \quad$ Avg. \%vol. & $\%$ & $\begin{array}{r}1.97 \\
\pm 0.73\end{array}$ & $\begin{array}{c}7.83 \\
\pm 0.65\end{array}$ & $\begin{array}{c}9.84 \\
\pm 0.55\end{array}$ & $\begin{array}{r}32.36 \\
\pm 5.42\end{array}$ & $\begin{array}{c}5.45 \\
\pm 0.48\end{array}$ \\
\hline 10 & He Avg. \%vol. & $\%$ & $\begin{array}{r}13.51 \\
\pm 1.71 \\
\end{array}$ & $\begin{array}{r}19.61 \\
\pm 0.63 \\
\end{array}$ & $\begin{array}{r}19.12 \\
\pm 0.26 \\
\end{array}$ & $\begin{array}{r}18.85 \\
\pm 0.92\end{array}$ & $\begin{array}{r}18.87 \\
\pm 0.50\end{array}$ \\
\hline 11 & $\mathrm{H}_{2} \mathrm{O}$ Avg. \%vol. & $\%$ & $\begin{array}{r}81.77 \\
\pm 2.58 \\
\end{array}$ & $\begin{array}{r}67.37 \\
\pm 1.27 \\
\end{array}$ & $\begin{array}{r}65.92 \\
\pm 0.64 \\
\end{array}$ & $\begin{array}{r}34.78 \\
\pm 5.84 \\
\end{array}$ & $\begin{array}{r}68.88 \\
\pm 1.12 \\
\end{array}$ \\
\hline 12 & $\mathrm{H}_{2} \quad$ Avg. \%vol. & $\%$ & $\begin{array}{c}2.03 \\
\pm 0.40\end{array}$ & $\begin{array}{r}3.00 \\
\pm 0.29\end{array}$ & $\begin{array}{c}2.43 \\
\pm 0.16\end{array}$ & $\begin{array}{c}5.24 \\
\pm 0.87\end{array}$ & $\begin{array}{c}2.84 \\
\pm 0.23\end{array}$ \\
\hline 13 & $\begin{array}{l}\text { Avg. } \\
\mathrm{H}_{2} \text {-LSQ Slope }\end{array}$ & $\mu \mathrm{g} / \mathrm{min}$ & $\begin{array}{r}3.33 \\
\pm 0.18 \\
\end{array}$ & $\begin{array}{r}2.26 \\
\pm 0.14 \\
\end{array}$ & $\begin{array}{r}7.78 \\
\pm 0.53 \\
\end{array}$ & $\begin{array}{r}1.51 \\
\pm 0.24 \\
\end{array}$ & $\begin{array}{r}2.45 \\
\pm 0.10 \\
\end{array}$ \\
\hline 14 & $\begin{array}{l}\text { Avg. } \mathrm{H}_{2} \mathrm{O} \\
\text { Removal Rate }\end{array}$ & $\mathrm{g} / \mathrm{h}$ & $\begin{array}{l}0.48 \\
\pm 0.27\end{array}$ & $\begin{array}{c}0.04 \\
\pm 0.04\end{array}$ & $\begin{array}{c}0.04 \\
\pm 0.04\end{array}$ & $\begin{array}{c}0.004 \\
\pm 0.011\end{array}$ & $\begin{array}{r}0.18 \\
\pm 0.32\end{array}$ \\
\hline 15 & $\begin{array}{l}\text { Avg. Air } \\
\text { Inleak Rate }\end{array}$ & $\mathrm{mL} / \mathrm{h}$ & $\begin{array}{l}0.06 \\
\pm 0.01\end{array}$ & $\begin{array}{c}0.24 \\
\pm 0.03\end{array}$ & $\begin{array}{c}0.30 \\
\pm 0.04\end{array}$ & $\begin{array}{c}0.98 \\
\pm 0.14\end{array}$ & $\begin{array}{c}0.42 \\
\pm 0.18\end{array}$ \\
\hline 16 & $\begin{array}{l}\text { Avg. } \\
\text { Reactive Area }\end{array}$ & $\mathrm{m}^{2}$ & $\begin{array}{r}1.58 \\
\pm 0.60\end{array}$ & $\begin{array}{c}1.61 \\
\pm 0.11\end{array}$ & $\begin{array}{c}5.64 \\
\pm 0.39\end{array}$ & $\begin{array}{r}1.64 \\
\pm 0.28\end{array}$ & $\begin{array}{r}1.61 \\
\pm 0.10\end{array}$ \\
\hline
\end{tabular}




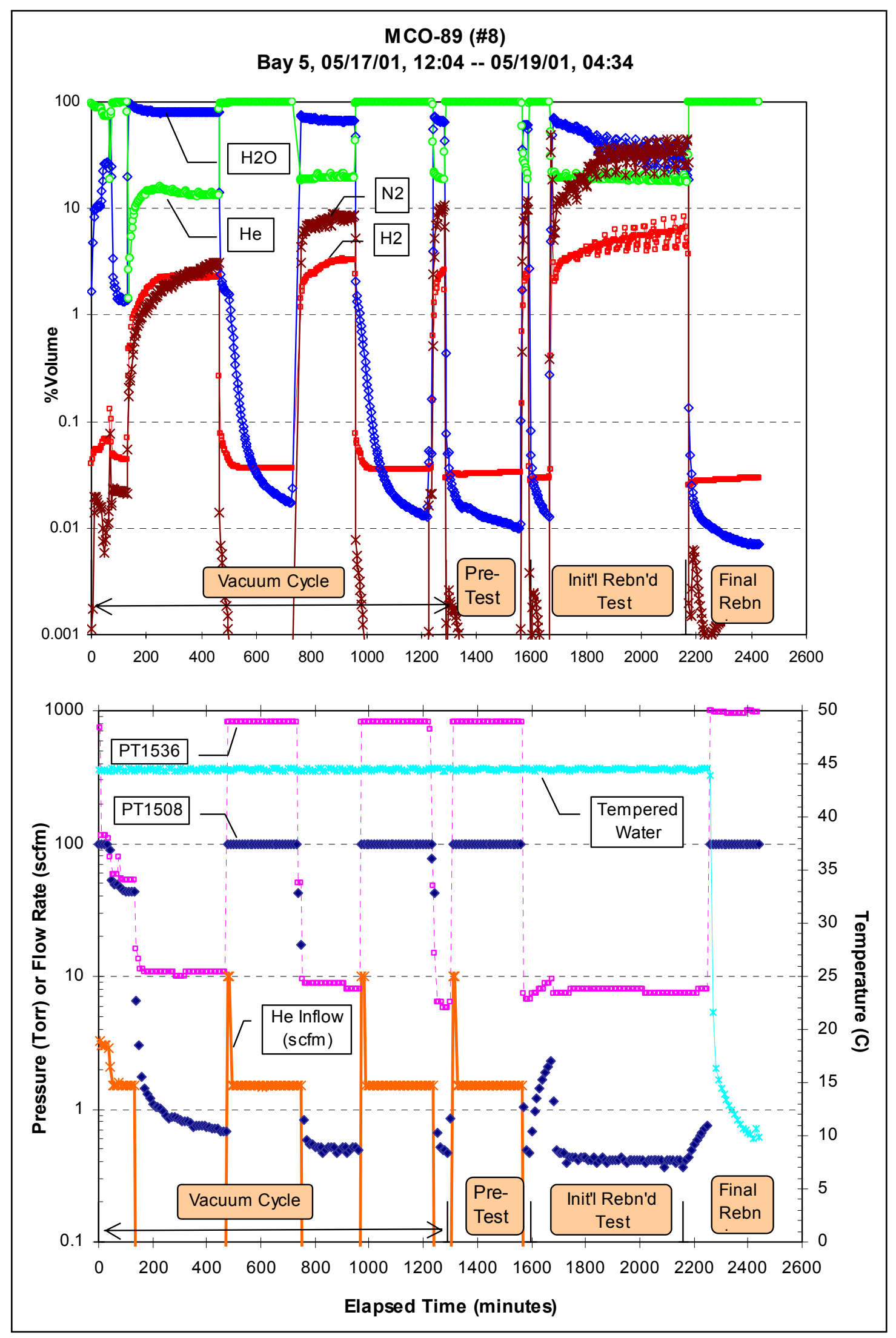

Figure B6.1. Data Overview for MCO-89 Drying Process 


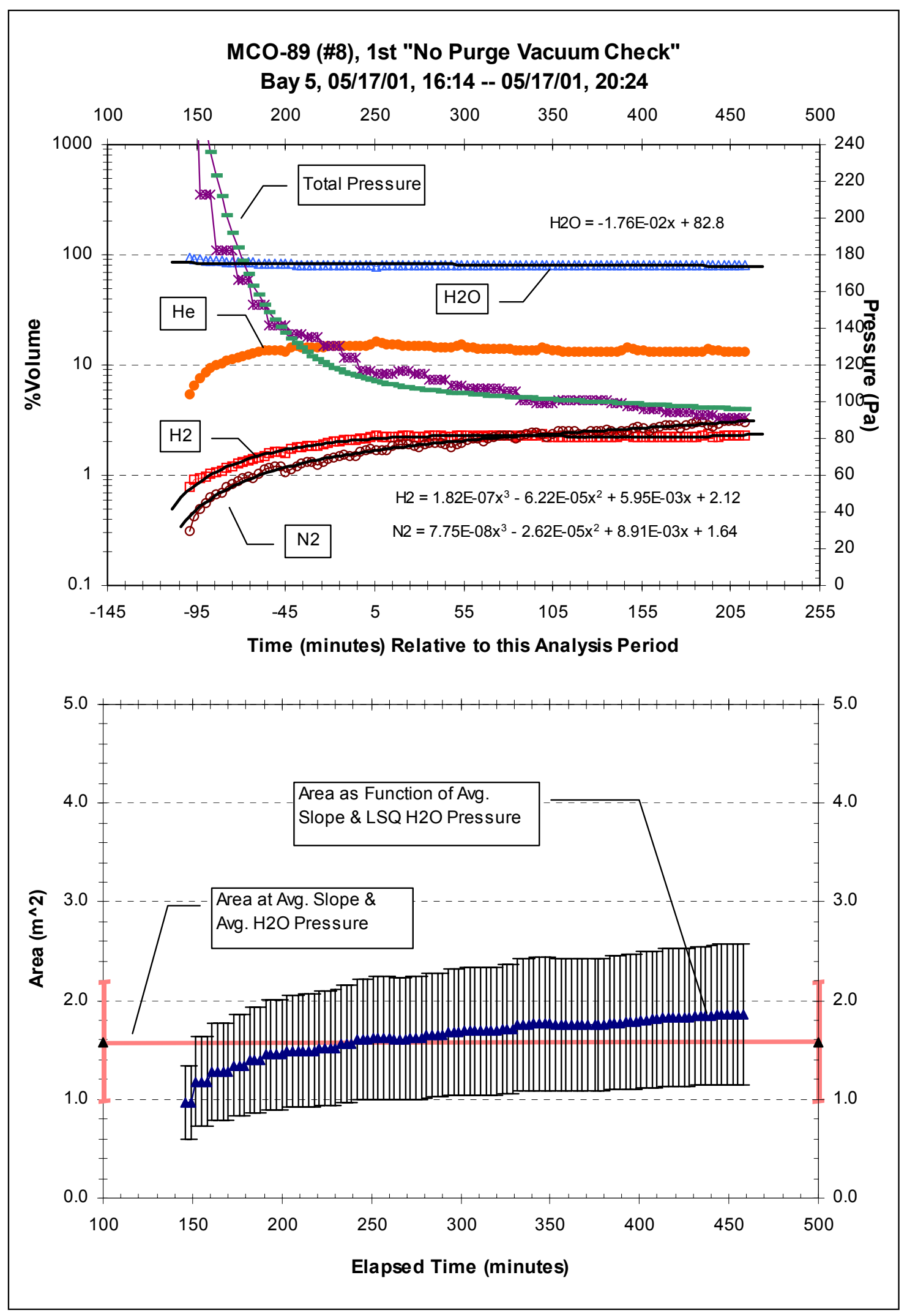

Figure B6.2. Surface Area for Vacuum Cycle 1 Segment of MCO-89 


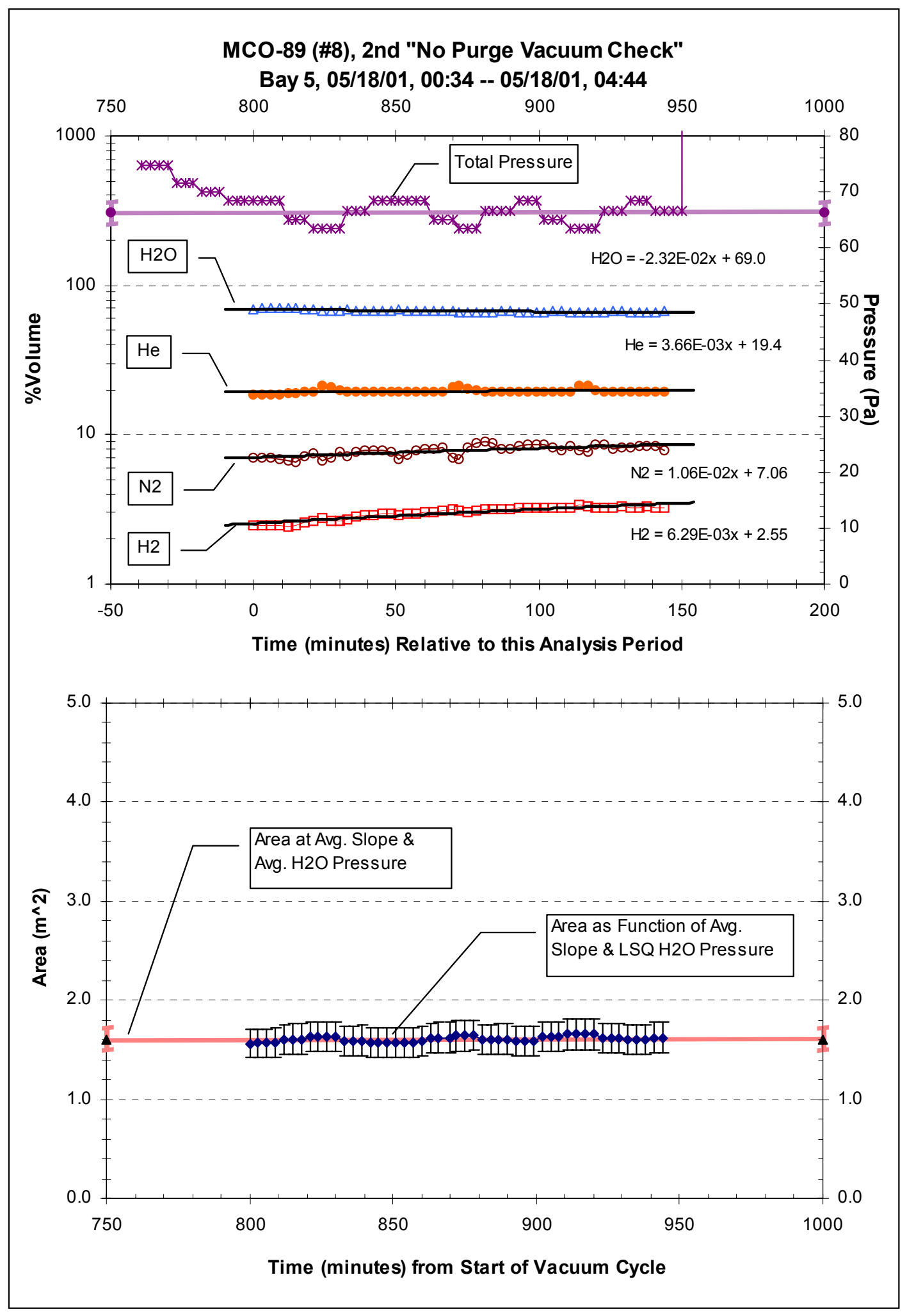

Figure B6.3. Surface Area for Vacuum Cycle 2 Segment of MCO-89 


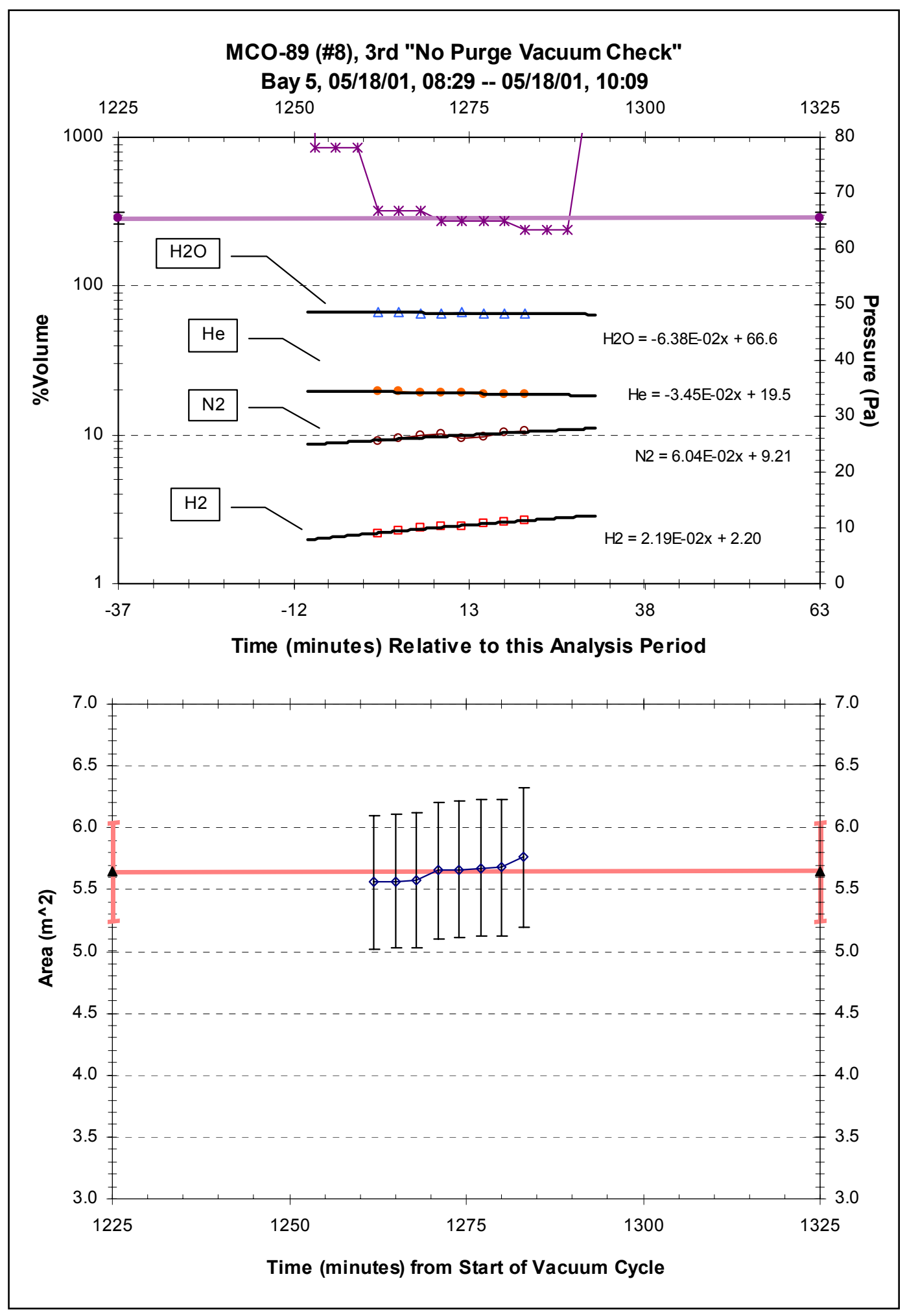

Figure B6.4. Surface Area for Vacuum Cycle 3 Segment of MCO-89 


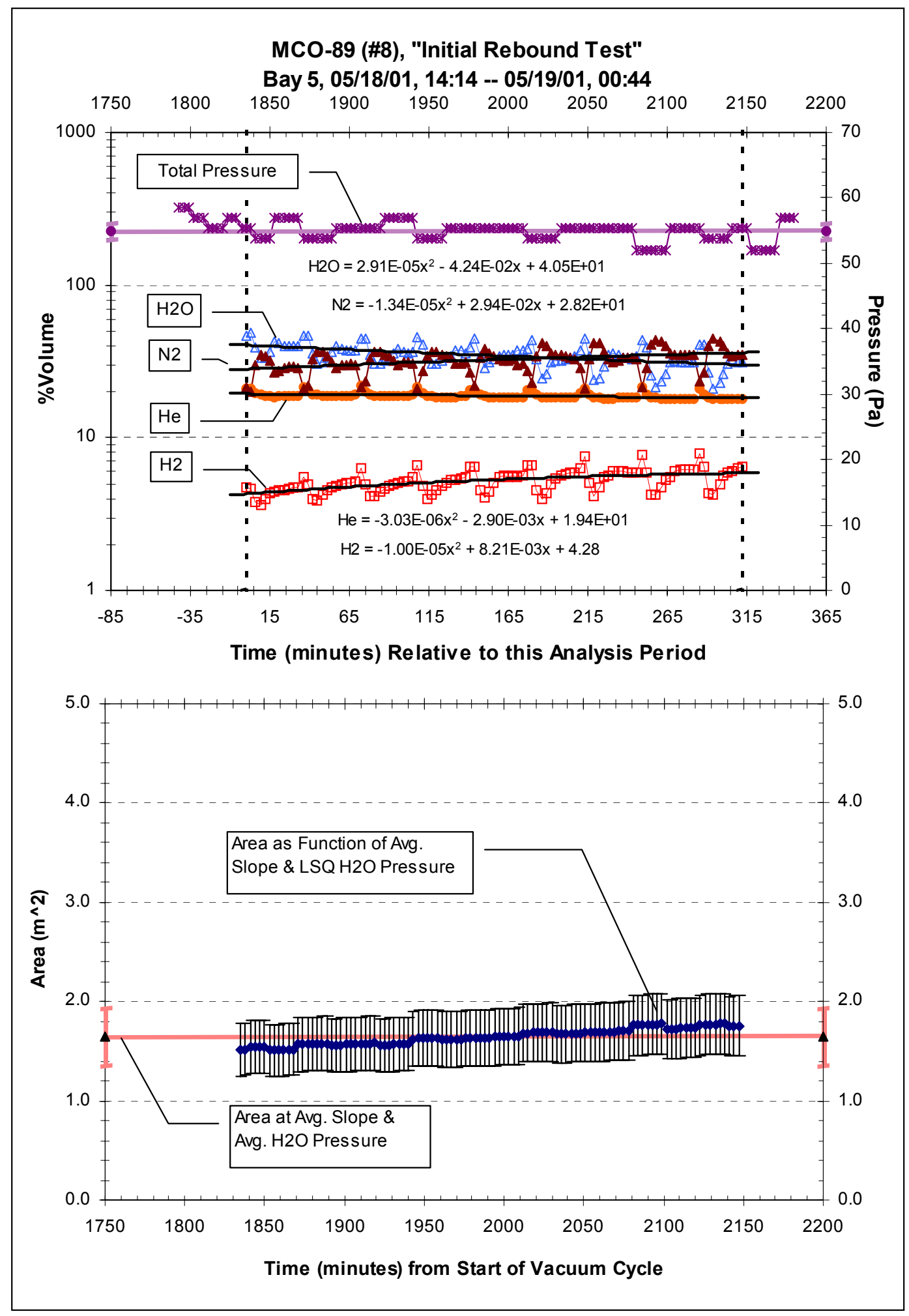

Figure B6.5. Surface Area for IRT Segment of MCO-89 


\section{B.7. MCOs-82 \& 88 Drying Process Analyses}

\begin{tabular}{|c|c|c|c|c|c|c|}
\hline 1 & $\begin{array}{l}\text { MCO 82 \& } 88 \\
(\text { Seq.\#7 \& \#9) }\end{array}$ & \multicolumn{5}{|c|}{$\begin{array}{c}\text { Vacuum Cycle Start Date \& Time (SDT) } \\
5 / 10 / 01,03: 42 \& 5 / 30 / 01,18: 18\end{array}$} \\
\hline 2 & \multicolumn{2}{|c|}{ Process $\Rightarrow$} & $\begin{array}{c}\# 7 \\
\text { VacCy- } \\
1\end{array}$ & $\begin{array}{c}\# 9 \\
\text { VacCy- } \\
1\end{array}$ & $\begin{array}{c}\# 9 \\
\text { VacCy- } \\
2\end{array}$ & \multirow{4}{*}{$\begin{array}{c}\# 9 \\
\text { Averages }\end{array}$} \\
\hline 3 & \multicolumn{2}{|c|}{$\begin{array}{c}\mathbf{t}=0 \text { \& End Pts. for Analysis } \\
\text { (min from SDT) }\end{array}$} & & & & \\
\hline 4 & \multicolumn{2}{|l|}{ Figure No. $\Rightarrow$} & B7.2 & B7.3 & B7.4 & \\
\hline & Data Type $\Downarrow$ & Units $\downarrow$ & & & & \\
\hline 5 & Avg. Temp. & $\mathrm{K}$ & $\begin{array}{c}317.60 \pm \\
0.10\end{array}$ & $\begin{array}{c}317.64 \pm \\
0.10\end{array}$ & $\begin{array}{c}317.64 \pm \\
0.11\end{array}$ & $\begin{array}{c}317.64 \pm \\
0.07\end{array}$ \\
\hline 6 & $\begin{array}{l}\text { Avg. Total } \\
\text { Press. } \\
\end{array}$ & $\mathrm{Pa}$ & $\begin{array}{c}128.61 \\
\pm 12.20\end{array}$ & $\begin{array}{r}129.57 \\
\pm 27.93\end{array}$ & $\begin{array}{r}83.27 \\
\pm 3.74 \\
\end{array}$ & $\begin{array}{r}84.09 \\
\pm 3.71\end{array}$ \\
\hline 7 & Avg. Total Moles & mMoles & $\begin{array}{r}34.58 \\
\pm 3.28\end{array}$ & $\begin{array}{r}34.83 \\
\pm 7.51\end{array}$ & $\begin{array}{r}22.39 \\
\pm 1.00\end{array}$ & $\begin{array}{l}22.61 \\
\pm 1.00\end{array}$ \\
\hline 8 & $\begin{array}{l}\text { Vacuum Pump } \\
\text { OutFlow Rate }\end{array}$ & $\begin{array}{l}\text { mMoles } \\
\text { per min }\end{array}$ & $\begin{array}{r}40.99 \\
\pm 4.60\end{array}$ & $\begin{array}{c}41.34 \\
\pm 10.52\end{array}$ & $\begin{array}{l}23.91 \\
\pm 1.40\end{array}$ & $\begin{array}{l}24.22 \\
\pm 1.39\end{array}$ \\
\hline 9 & $\mathrm{~N}_{2} \quad$ Avg. \%vol. & $\%$ & $\begin{array}{r}1.39 \\
\pm 0.43 \\
\end{array}$ & $\begin{array}{c}1.77 \\
\pm 0.65\end{array}$ & $\begin{array}{r}5.32 \\
\pm 0.65 \\
\end{array}$ & $\begin{array}{c}3.55 \\
\pm 0.46 \\
\end{array}$ \\
\hline 10 & He Avg. \%vol. & $\%$ & $\begin{array}{c}9.78 \\
\pm 1.25 \\
\end{array}$ & $\begin{array}{r}14.89 \\
\pm 2.05 \\
\end{array}$ & $\begin{array}{r}17.02 \\
\pm 0.58 \\
\end{array}$ & $\begin{array}{r}16.87 \\
\pm 0.56\end{array}$ \\
\hline 11 & $\mathrm{H}_{2} \mathrm{O}$ Avg. \%vol. & $\%$ & $\begin{array}{l}86.41 \\
\pm 1.96 \\
\end{array}$ & $\begin{array}{r}81.50 \\
\pm 2.42 \\
\end{array}$ & $\begin{array}{r}74.62 \\
\pm 0.90 \\
\end{array}$ & $\begin{array}{l}75.46 \\
\pm 0.85 \\
\end{array}$ \\
\hline 12 & $\mathrm{H}_{2} \quad$ Avg. \%vol. & $\%$ & $\begin{array}{c}1.81 \\
\pm 0.34 \\
\end{array}$ & $\begin{array}{c}1.14 \\
\pm 0.15 \\
\end{array}$ & $\begin{array}{c}1.44 \\
\pm 0.13 \\
\end{array}$ & $\begin{array}{c}1.31 \\
\pm 0.10 \\
\end{array}$ \\
\hline 13 & $\begin{array}{l}\text { Avg. } \\
\mathrm{H}_{2} \text {-LSQ Slope }\end{array}$ & $\mu \mathrm{g} / \mathrm{min}$ & $\begin{array}{c}3.90 \\
\pm 0.20 \\
\end{array}$ & $\begin{array}{c}1.85 \\
\pm 0.12 \\
\end{array}$ & $\begin{array}{c}2.87 \\
\pm 0.31 \\
\end{array}$ & $\begin{array}{c}1.97 \\
\pm 0.11 \\
\end{array}$ \\
\hline 14 & $\begin{array}{l}\text { Avg. } \mathrm{H}_{2} \mathrm{O} \\
\text { Removal Rate }\end{array}$ & $\mathrm{g} / \mathrm{h}$ & $\begin{array}{c}0.48 \\
\pm 0.31\end{array}$ & $\begin{array}{c}0.57 \\
\pm 0.34\end{array}$ & $\begin{array}{c}0.17 \\
\pm 0.13\end{array}$ & $\begin{array}{c}0.37 \\
\pm 0.47\end{array}$ \\
\hline 15 & $\begin{array}{l}\text { Avg. Air } \\
\text { Inleak Rate }\end{array}$ & $\mathrm{mL} / \mathrm{h}$ & $\begin{array}{l}0.02 \\
\pm 0.00\end{array}$ & $\begin{array}{l}0.03 \\
\pm 0.01\end{array}$ & $\begin{array}{l}0.10 \\
\pm 0.03\end{array}$ & $\begin{array}{l}0.07 \\
\pm 0.05\end{array}$ \\
\hline 15 & $\begin{array}{l}\text { Avg. } \\
\text { Reactive Area }\end{array}$ & $\mathrm{m}^{2}$ & $\begin{aligned} & 1.76 \\
\pm & 0.25\end{aligned}$ & $\begin{array}{c}0.85 \\
\pm 0.15\end{array}$ & $\begin{array}{c}1.73 \\
\pm 0.23\end{array}$ & $\begin{array}{r}1.27 \\
\pm 0.13\end{array}$ \\
\hline
\end{tabular}




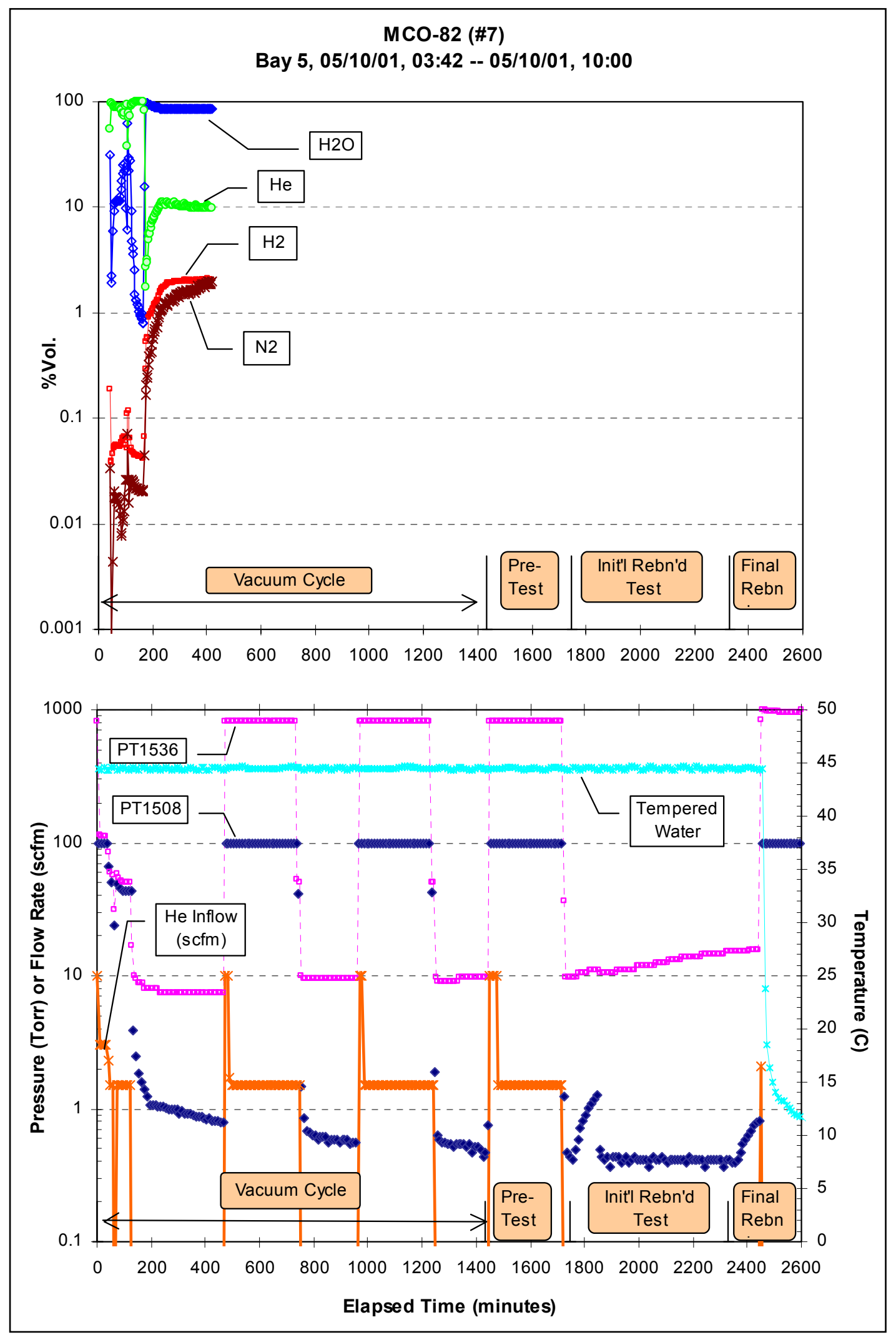

Figure B7.1. Data Overview for MCO-82 Drying Process 


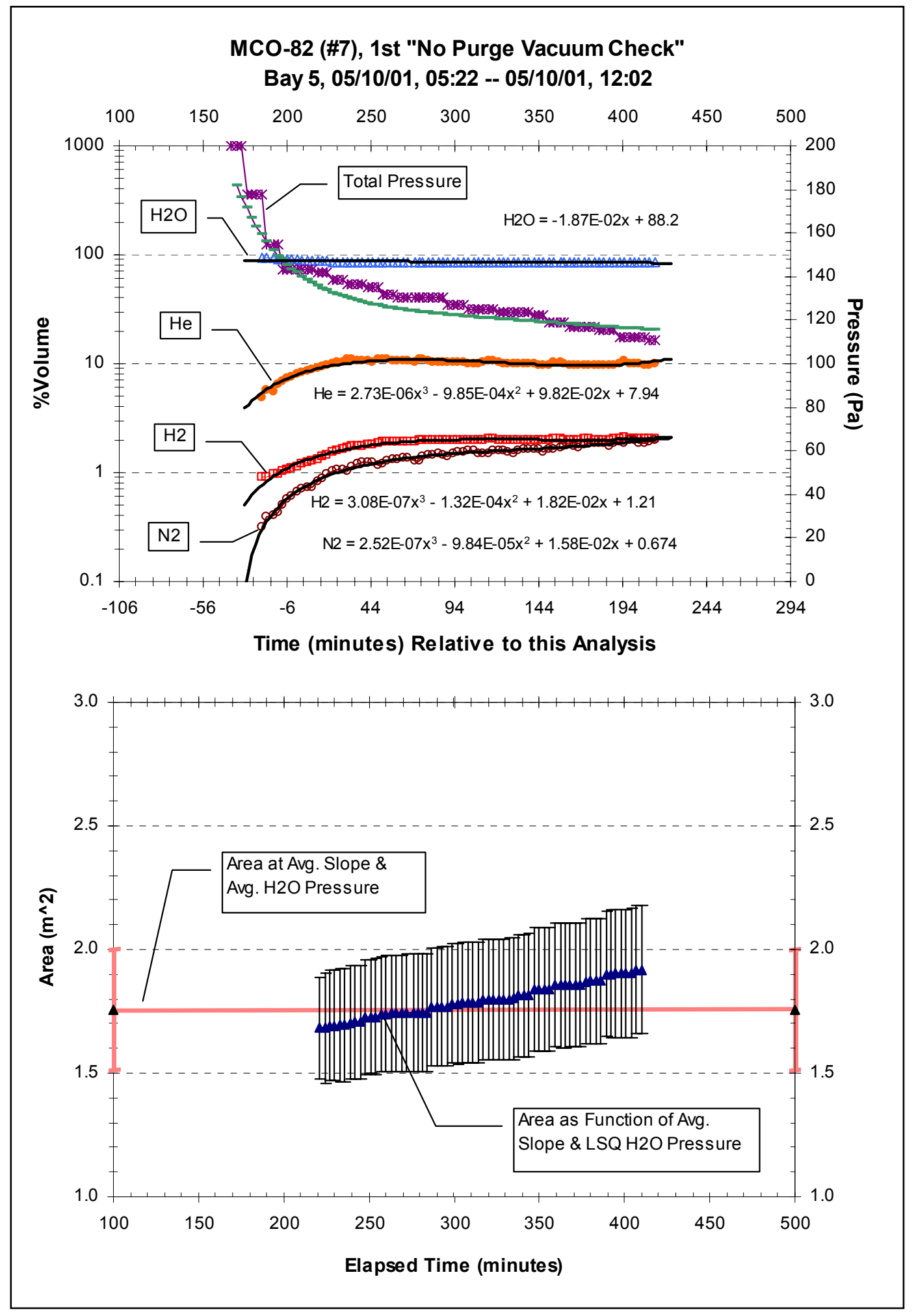

Figure B7.2. Surface Area of Vacuum Cycle 1 Segment for MCO-82 


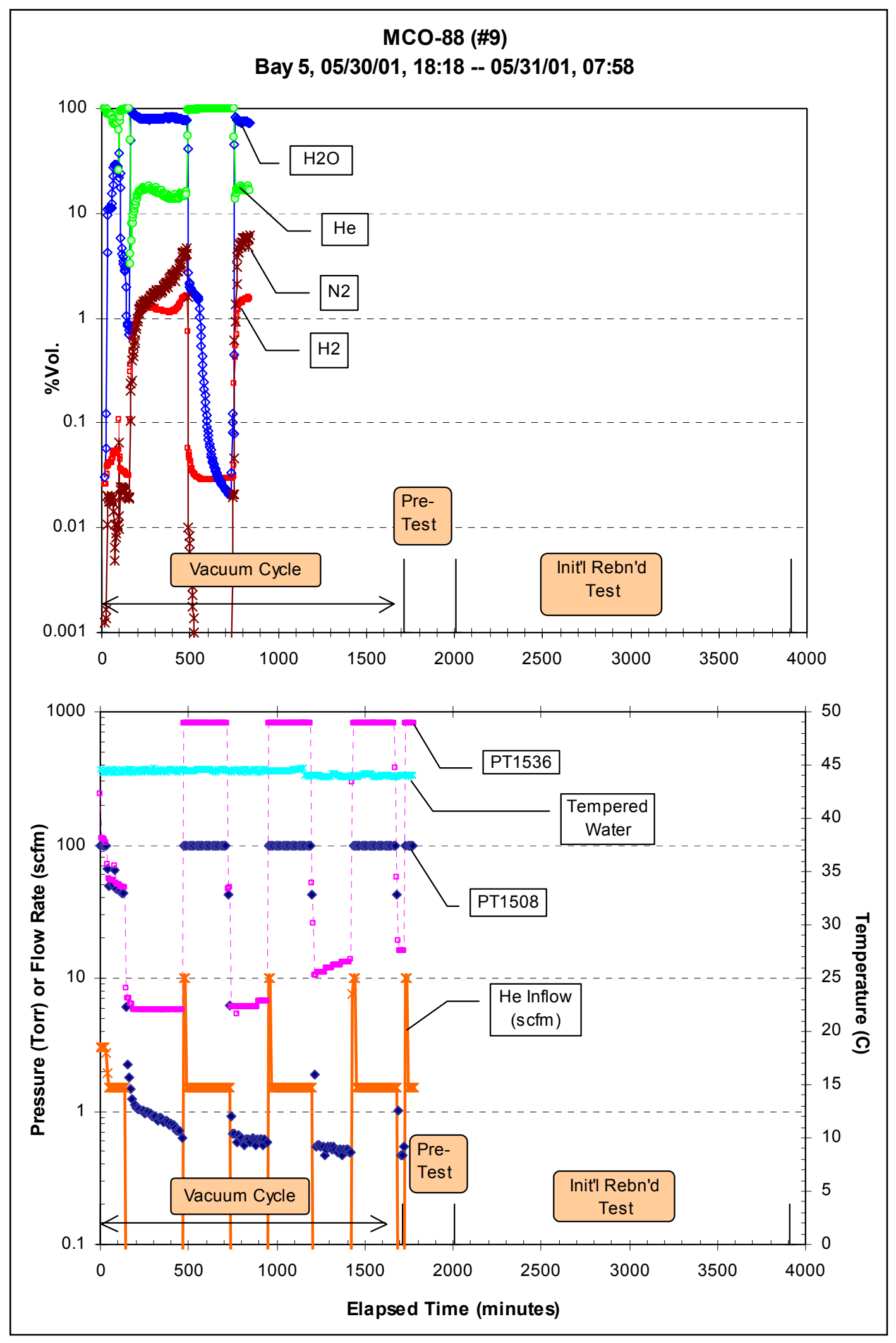

Figure B7.3. Data Overview for MCO-88 Drying Process 


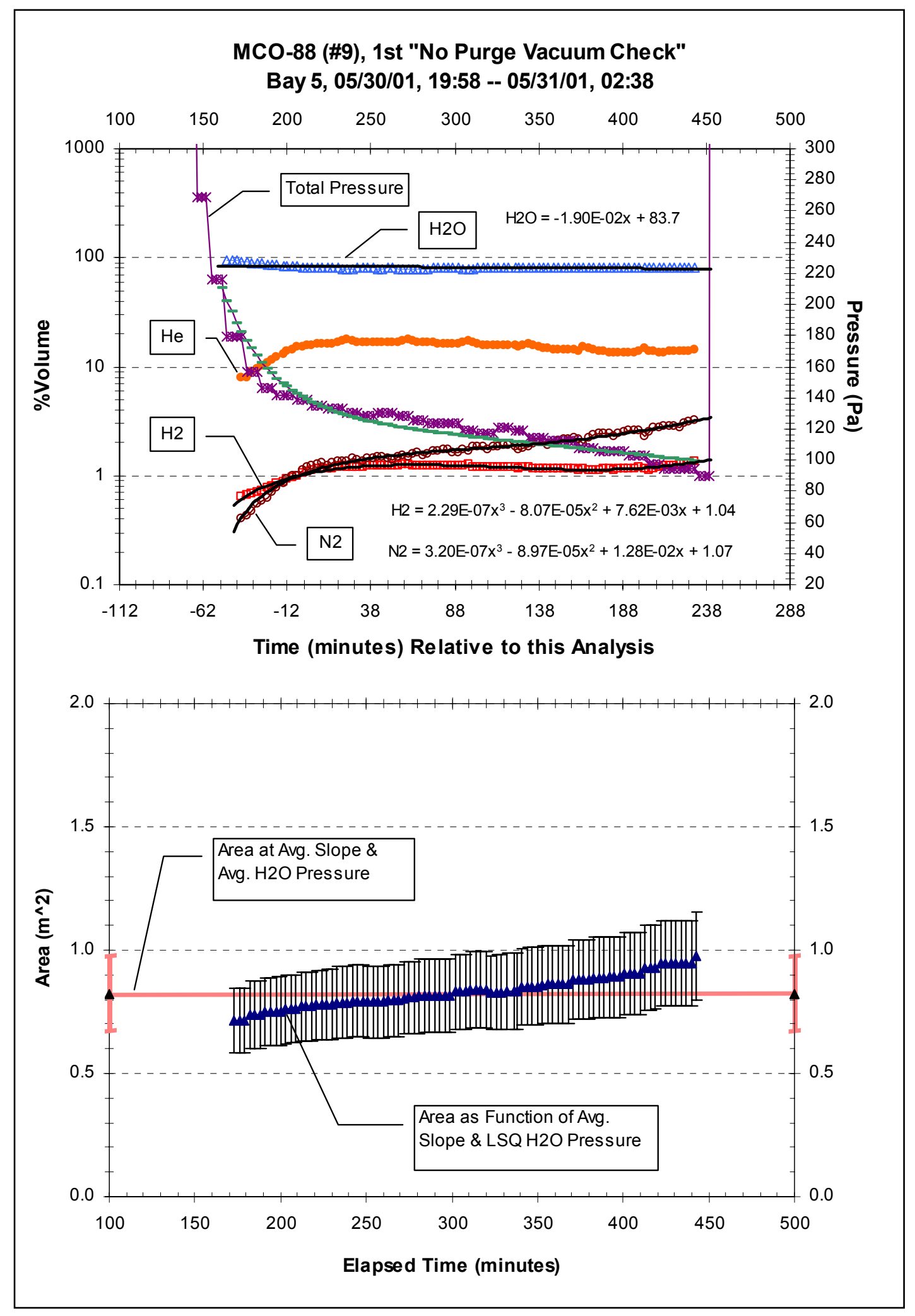

Figure B7.4. Surface Area of Vacuum Cycle 1 Segment for MCO-88 


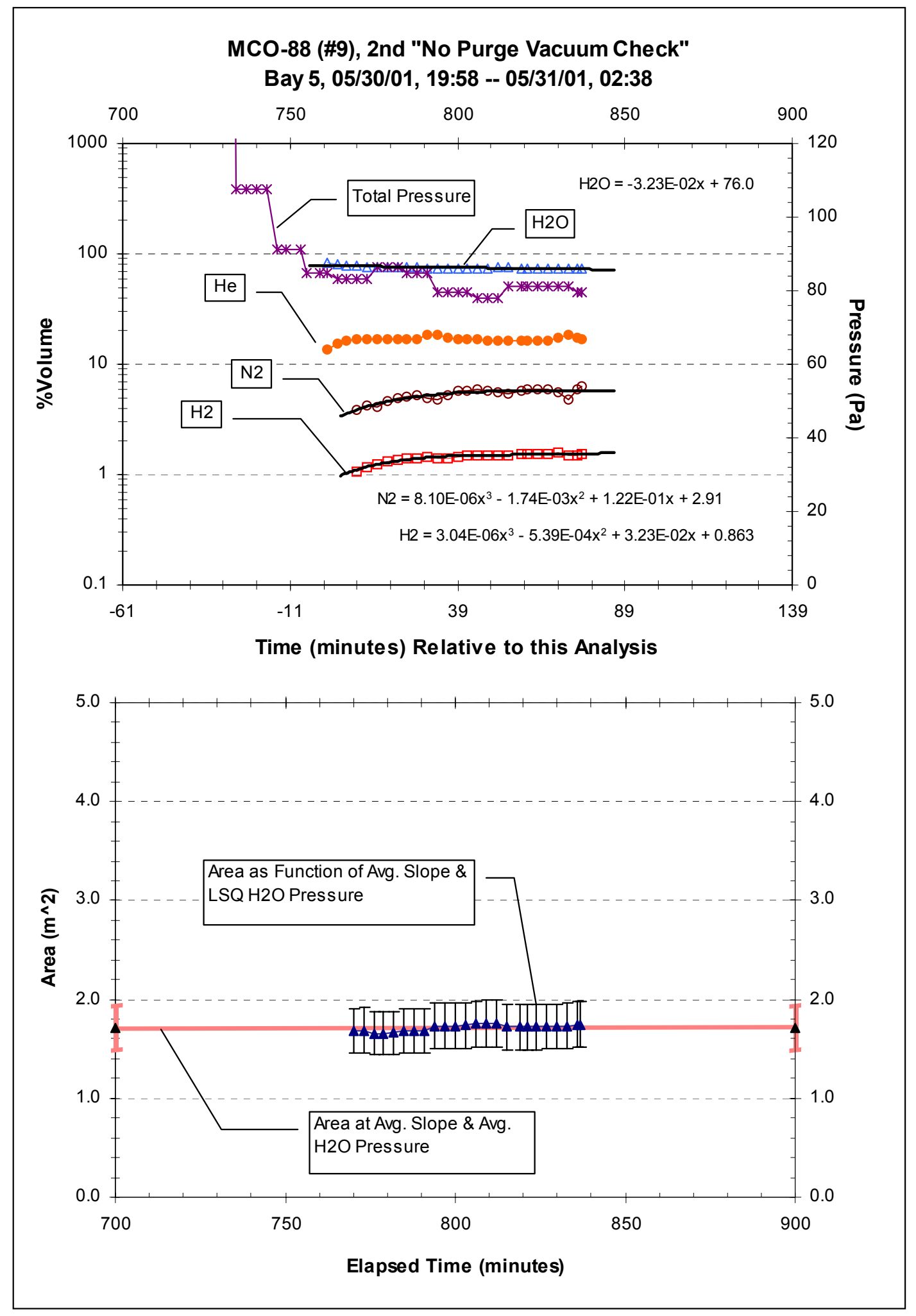

Figure B7.5. Surface Area of Vacuum Cycle 2 Segment for MCO-88 


\section{Distribution List}

No. of

Copies

OFFSITE

Christian Dahl

Idaho National Engineering \& Environmental Laboratory

P.O. Box 1625

Idaho Falls, ID 83415

Philip Wheatley

Idaho National Engineering \& Environmental Laboratory

P.O. Box 1625

Idaho Falls, ID 83415
No. of

Copies

\section{ONSITE}

13 Pacific Northwest National Laboratory

J. Abrefah (5)

P7-27

W.F. Bonner (2)

K9-14

D.W. Damschen

K7-15

D.E. Knutson

P7-25

S.N. Schlahta

K9-91

P.A. Scott

K9-46

E.R. Siciliano

$\mathrm{K} 7-15$

T.L. Walton

K9-46

12 Flour Hanford, Inc.

R.M. Crawford

X3-79

D.R. Duncan

$\mathrm{X} 4-01$

E.N. Erickson

$\mathrm{X} 4-01$

C.S. Haller

X3-78

B.J. Makenas

L0-30

C.R. Miska

X3-78

F.W. Moore

$\mathrm{X} 4-01$

B.L. Philipp

$\mathrm{X} 3-78$

J.P. Sloughter

$\mathrm{X} 4-01$

J. Swenson

X3-78

D.R. Whitehurst

X3-78

J.J. Zimmer

X4-01

Distr. 1 